\title{
Construção e estudos sobre ontologias de bioquímica
}

Anderson Carlos Daniel Sanches

DISSERTAÇÃO APRESENTADA

$\mathrm{AO}$

INSTITUTO DE MATEMÁTICA E ESTATÍSTICA

DA UNIVERSIDADE DE SÃO PAULO

PARA OBTENÇÃO DO GRAU DE

MESTRE EM CIÊNCIA DA COMPUTAÇÃO

Área de Concentração: Ciência da Computação

Orientadora: Profa. Dra. Renata Wassermann 


\title{
Construção e estudos sobre ontologias de bioquímica
}

\author{
Este exemplar corresponde à redação \\ final da dissertação devidamente \\ corrigida e defendida por \\ Anderson Carlos Daniel Sanches \\ e aprovada pela comissão julgadora
}

São Paulo, dezembro de 2.005.

Banca examinadora:

- Prof. Dra. Renata Wassermann (Orientadora) - IME-USP

- Prof. Dra. Leliane de Barros - IME-USP

- Prof. Dra. Renata Vieira (UNISINOS) 
"A year spent in artificial intelligence is enough to make one believe in God."

Alan J. Perlis

\section{Agradecimentos}

A Renata Sanches, pelo companheirismo e cumplicidade.

Aos meus pais. Pela compreensão, apoio e incentivo. E principalmente pelas cobranças.

A Renata Wassermann, pela paciência ainda maior que os meus erros.

Aos componentes da banca avaliadora, pelas ótimas sugestões que recebi na qualificação. 


\section{Resumo}

A Biologia é uma ciência rica em informações, que depende do conhecimento. Ela se apresenta como um banco de conhecimento em que os biólogos adicionam mais conhecimento, já que um biólogo frequentemente utiliza-se de conhecimento pré-existente para inferir sobre o assunto pesquisado.

Essas informações são geralmente difíceis de serem representadas, devido a sua natureza por vezes incerta, incompleta, esparsa e em constante mudança. A partir disto surgem várias questões, em particular, como o conhecimento pode ser guardado de forma que seja utilizável por aplicativos. Uma das respostas a esta questão é o uso de ontologias para descrever este conhecimento.

Essa dissertação visa apresentar diversos conceitos relativos a ontologias, iniciando com os conceitos básicos de definição e utilidade, o que é e o que não é uma ontologia, além de suas aplicações. Depois que algumas ontologias são apresentadas, é feito um estudo sobre as principais linguagens, protocolos e editores para a descrição de ontologias. Então uma ontologia é proposta, norteada pelas diretrizes apresentadas. A partir da construção dessa ontologia, é possível comparar mais profundamente duas linguagens, OWL e PowerLoom, e estabelecer as principais diferenças acarretadas pela escolha de uma ou outra.

Palavras-chave: ontologia, bio-ontologia, PowerLoom, OWL, bioquímica, bioinformática. 


\begin{abstract}
Biology is a science rich in information, that depends on the knowledge. It presents itself as a knowledge bank in which biologists adds more knowledge, since a biologist frequently uses the preexisting information to infer on the seached subject.

This information is generally hard to be represented, due its nature, sometimes uncertain, incomplete, sparse and in constant change. Based on this question various issues come up, for example, how the knowledege could be stored in a way to be usable by aplications. One of the answers to this question ís the use of ontologies to describe this knowledge.

This thesis aims to present several concepts about ontologies, starting whith basic concepts of definitions and utility, what is and what is not an ontology, beyond its applications. After the presentation of some ontologies, it is made a study on the main languages, protocols and editors for describing ontologies. Then it is proposed an ontology, guided by the lines of direction exposed before. From the construction of this ontology, it is possible to compare two languages, OWL and PowerLoom more deeply, and to establish the main differences caused for the choice of one or another one.
\end{abstract}

Key-words: ontology, bio-ontology, PowerLoom, OWL, biochemistry, bioinformatics. 


\section{Sumário}

Lista de Tabelas

Lista de Figuras

1 Por que ontologias para biologia? $\quad$ p. 10

2 Definições de Ontologia $\quad$ p. 13

2.1 Ontologias: o que são e pra que servem? . . . . . . . . . . . . . . p. 13

2.1 .1 Definição da palavra . . . . . . . . . . . . . . . . . p. 13

2.1 .2 O que não é uma ontologia? . . . . . . . . . . . . . p. 16

2.2 Ontologia do ponto de vista da bioinformática: tipos e aplicações . . . . p. 17

3 Estudo de Algumas Bio-ontologias e Vocabulários Controlados p. 21

3.1 Gene Ontology . . . . . . . . . . . . . . . . . . . . p. 22

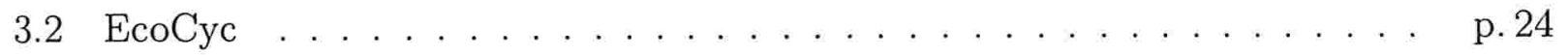

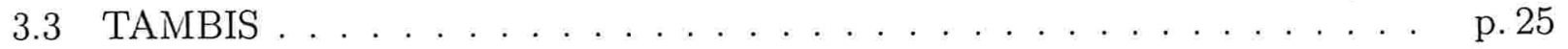

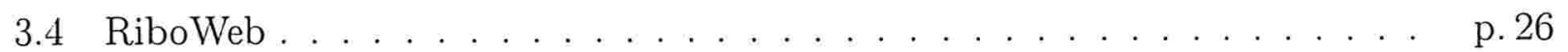

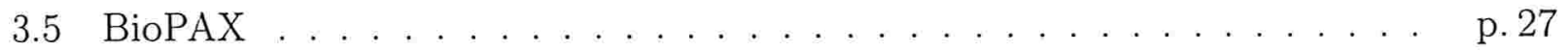

4 Ferramentas para a descrição de ontologias $\quad$ p. 28

4.1 Protocolos e Linguagens para descrição de ontologias . . . . . . . . . . p. 29

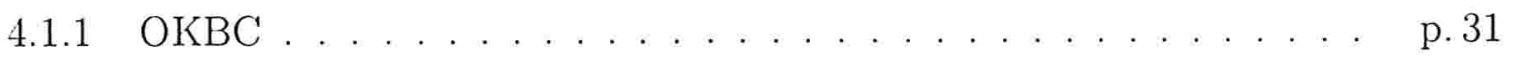




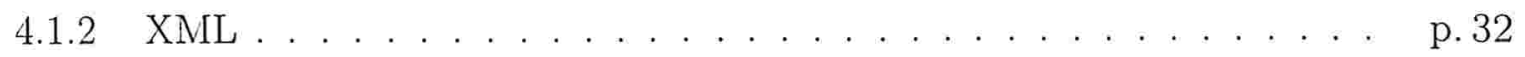

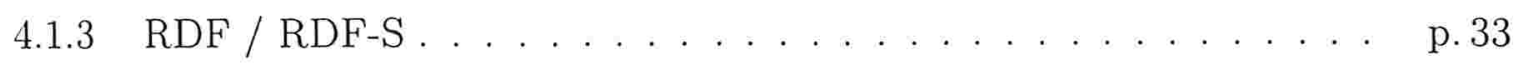

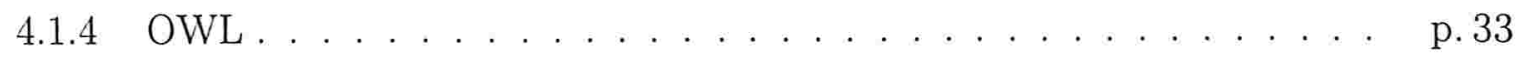

4.1 .5 LOOM e PowerLoom . . . . . . . . . . . . . . . p. 36

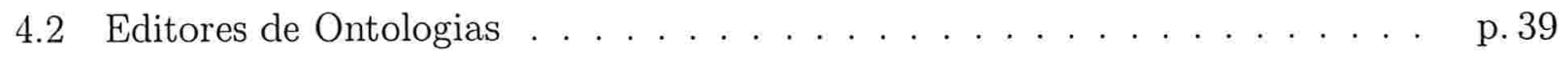

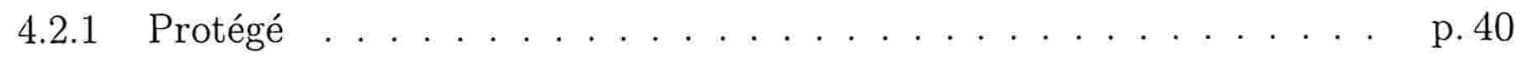

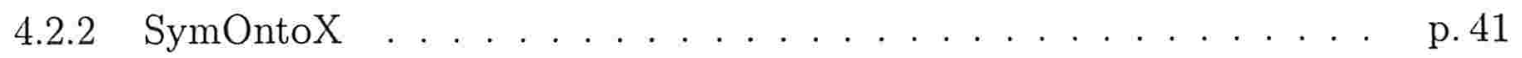

$4.2 .3 \quad$ OILED . . . . . . . . . . . . . . . . . . . . . . p. 42

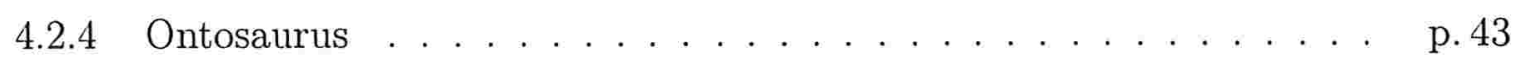

5 Construindo Uma Bio-Ontologia p. 44

5.1 Como construir uma Ontologia . . . . . . . . . . . . . . p. 44

5.1 .1 Regras para Nomear Conceitos $\ldots \ldots \ldots \ldots \ldots \ldots$ p. 45

5.1 .2 Integração entre Ontologias $\ldots \ldots \ldots \ldots \ldots \ldots$ p. 47

5.2 Ontologia Proposta . . . . . . . . . . . . . . . . . p. 48

5.3 Uma Ontologia Semelhante Usando OWL $\ldots \ldots \ldots \ldots \ldots$. . . . . . . .

5.4 Dificuldades Encontradas . . . . . . . . . . . . . . p. 57

6 Comparação entre PowerLoom e OWL p. 61

6.1 Por que OWL e PowerLoom? . . . . . . . . . . . . . . . p. 62

6.1 .1 Por que OWL? . . . . . . . . . . . . . . . 62

6.1 .2 Por que PowerLoom? . . . . . . . . . . . . . . p. 63

6.2 Representação do Conhecimento do Domínio . . . . . . . . . . . p.66

6.3 Raciocínio e Mecanismos de inferência $\ldots \ldots \ldots \ldots \ldots \ldots$ p. . . . . . .

6.4 Principais diferenças entre PowerLoom e OWL . . . . . . . . . . p. 84 
7 Conclusões e Trabalhos Futuros p. 86

7.1 Conclusões . . . . . . . . . . . . . . . . . . p. 86

7.2 Trabalhos Futuros . . . . . . . . . . . . . . . p. 87

Apêndice - Código Fonte da Ontologia Proposta $\quad$ p. 89

PowerLoom . . . . . . . . . . . . . . . . . . . . . p. 89

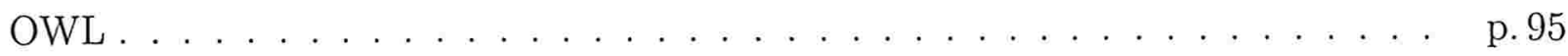

$\begin{array}{ll}\text { Referências } & \text { p. } 107\end{array}$ 


\section{Lista de Tabelas}

1 Framework CommonKADS de avaliação. . . . . . . . . . . . . . p. 62

2 Definições dos componentes principais do conhecimento do domínio. . . . . p. 69

3 Definições de Conceitos. . . . . . . . . . . . . . . . . . . p. 69

4 Definições de taxonomias. . . . . . . . . . . . . . . . . . p. 71

5 Definições de relacionamentos e funções. . . . . . . . . . . . . . . p. 73

6 Definições de instâncias. . . . . . . . . . . . . . . . . . . . p. 73

7 Definições de axiomas. . . . . . . . . . . . . . . . . . p. 74

8 Mecanismos de raciocínio das linguagens. . . . . . . . . . . . p. 78 


\section{Lista de Figuras}

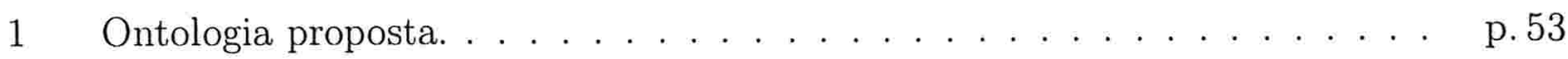

2 Zoom no conceito Carboidrato, onde pode-se ver a repetição dos mesmos subconceitos e instâncias tanto em Carboidrato quanto Glicidio. . . . . . . p. p.54

3 Visualização no Ontosaurus. Nessa figura pode ser visto o formulário de

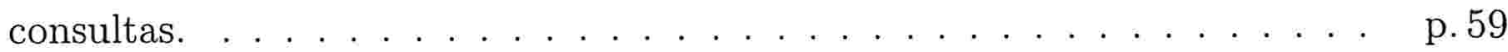

4 As instâncias de Monossacarídeo. . . . . . . . . . . . . . . . . . p.91 


\section{Por que ontologias para biologia?}

Biólogos necessitam de conhecimento para realizarem seus trabalhos. Um biólogo freqüentemente irá usar algum tipo de conhecimento pré-existente para fazer inferências sobre o assunto pesquisado. Um exemplo é o uso de comparação de seqüências para inferir a função de uma nova seqüência de proteínas, ou até a descoberta de novos caminhos metabólicos (SIRAVA et al., 2002). A causa disto é que se uma seqüência de função desconhecida é altamente similar a outra de função conhecida, então é provável que a nova seqüência também tenha a mesma função. Então, ao invés de usar uma regra, lei ou equação para encontrar a função da proteína, é mais fácil para um biólogo, usar o conhecimento de que uma seqüência similar tem uma função conhecida, para fazer um julgamento sobre a função da nova seqüência. Esta é a razão de os biólogos dizerem que Biologia é uma disciplina baseada em conhecimento, ao invés das disciplinas "baseadas em axiomas".

Biologia é uma ciência rica em informações, que se apresentam como um banco de conhecimento em que os biólogos adicionam mais conhecimento. Essas informações são geralmente difíceis de se representar já que são por vezes incompletas, incertas, multi-dimensionais apesar de esparsas e em constante mudança (BATTISTELLA et al., 2004). Este conhecimento é guardado em centenas de bancos de dados e muitos deles precisam ser usados coordenadamente durante uma pesquisa. Conhecimento é vital em duas partes durante este processo. Quando é usado mais de um repositório de conhecimento, um biólogo precisa estar seguro de que o conhecimento de um repositório pode ser comparado confiantemente com o outro. Um primeiro exemplo pode ser o diferente uso do termo "gene", dentro da comunidade de pesquisadores. Em alguns bancos de dados, gene pode ser definido como "a região de codificação do DNA", em outro como "um fragmento do DNA que pode ser transcrito e traduzido em uma proteína" ou ainda, "região de interesse biológico do DNA que possui um nome e que transporta características genéticas ou fenótipos" (SCHULZE-KREMER, 2002). Comparar 
diferentes definições para poder avaliar os repositórios, seria uma vantagem. É necessário também definir e restringir informação em um repositório. Informações biológicas podem ser muito complexas. Não apenas no tipo de dados armazenado, mas também na riqueza e no trabalho de estabelecimento das relações entre estas informações.

É importante para um único biólogo poder lidar com diversos domínios do conhecimento. O surgimento dos mapeamentos dos genomas de várias espécies só realça essa situação. Existe, entretanto, uma necessidade de criar sistemas que podem transcrever o conhecimento dos especialistas do domínio em informações biológicas representadas em software. Ainda não está claro se estes sistemas especialistas podem ser melhores para fazer novas descobertas do que os especialistas humanos, entretanto, estes sistemas podem ter um papel crucial na ajuda do processamento de informações e interagir com estes especialistas. A partir disto surgem várias questões, em particular, como o conhecimento pode ser guardado de forma que seja utilizável por aplicativos.

Uma das respostas a esta questão é o uso de ontologias para descrever este conhecimento, tornado-o utilizável por pessoas e máquinas. A premissa da necessidade de ontologias em bioinformática é a necessidade de disponibilizar o conhecimento para a comunidade e para aplicativos.

O objetivo do trabalho é comparar os principais mecanismos de inferência existentes para as linguagens OWL e PowerLoom em relação às características desejáveis para a manipulação de bio-ontologias, juntamente com suas capacidades de representação de conhecimento, sendo que para isso foram estudadas diversas bio-ontologias existentes, e uma nova foi proposta, após estudos de como construí-la.

No próximo capítulo será explicado o conceito de ontologia, suas definições e usos. No capítulo 3 serão estudadas algumas das bio-ontologias mais conhecidas, como o Gene Ontology e o EcoCyc. No capítulo 4 serão comparadas as principais linguagens e protocolos para descrição de ontologias, além dos editores mais conhecidos. No capítulo 5, serão apresentados os conceitos que devem ser levados em conta para a construção de uma bio-ontologia. Logo após, uma bio-ontologia será proposta, descrita nas linguagens PowerLoom e OWL, seguida pelas dificuldades encontradas durante a sua confecção. No capítulo 6 serão comparados PowerLoom e OWL, em termos de suas capacidades de representação de conhecimento e mecanismos de inferência, concluindo-se o trabalho no capítulo seguinte, onde são apresentadas 
as conclusões e perspectivas de trabalhos futuros. No apêndice há o código-fonte completo das ontologias propostas, tanto em PowerLoom como em OWL. 


\section{Definições de Ontologia}

\subsection{Ontologias: o que são e pra que servem?}

\subsubsection{Definição da palavra}

Inicialmente, pode-se caracterizar ontologia, para a comunidade de Inteligência Artificial, como uma definição das entidades e das relações entre elas, relevantes a um ou mais domínios, para um entendimento compartilhado explícito em uma linguagem (GUARINO; GIARETTA, 1995). Entretanto, seu significado tende a permanecer um pouco vago, já que o termo é usado em diferentes significações, como será visto no próximo capítulo. (GUARINO; GIARETTA, 1995) enumera sete diferentes interpretações:

1. Ontologia como uma disciplina da Filosofia, trata da organização e da natureza da realidade, e geralmente é escrita com o 'O' maiúsculo;

2. Ontologia como um sistema conceitual informal;

3. Ontologia como uma proposta de semântica formal;

4. Ontologia como uma especificação de uma "conceituação";

5. Ontologia como uma representação de um sistema conceitual através de uma teoria lógica:

(a) caracterizada por propriedades formais ou

(b) caracterizada apenas para propósitos específicos;

6. Ontologia como um vocabulário usado por uma teoria lógica;

7. Ontologia como um meta-nível de especificação de uma teoria lógica. 
As interpretações 2 e 3 concebem uma ontologia como entidade conceitual semântica, formal ou informal, enquanto nas interpretações 5 - 7 uma ontologia é objeto sintático específico. A interpretação 4, que pode ser definida como a interpretação mais próxima da definição de o que é uma ontologia para a comunidade de Inteligência Artificial, é a que mais desperta interesse. Ela pode ser classificada como sintática, mas seu significado preciso também depende do entendimento dos termos "especificação" e "conceituação".

Na interpretação 3, ao contrário, a ontologia que suporta uma base de conhecimento é expressa em termos de estruturas formais satisfatórias no nível semântico. Em ambos os casos, pode-se dizer que "a ontologia da base de conhecimento 1 é diferente daquela da base de conhecimento 2 ".

Na interpretação 5, uma ontologia não é nada mais que uma teoria lógica. A questão é se essa teoria necessita ter uma descrição formal para ser uma ontologia, ou então é suficiente considerar qualquer teoria lógica como uma ontologia. Esta última posição é apoiada por aqueles que defendem que uma ontologia é uma coleção de afirmações formais (formal assertions), anotada e indexada, sobre algo. Somente a coleção das afirmações, na lógica, é chamada de teoria.

De acordo com a interpretação 6, uma ontologia não é vista como uma teoria lógica, ela é apenas o vocabulário usado por uma teoria lógica. Esta interpretação recai na 5(a) quando uma ontologia é pensada como uma especificação de um vocabulário que consiste de uma coleção de definições lógicas. Pode-se dizer que a interpretação 4 também recai na 5(a) se uma conceituação for planejada como um vocabulário. O problema é deixar claro o que significa o termo "conceituação".

Finalmente, sob a interpretação 7, uma ontologia é vista como um meta-nível de especificação de uma teoria lógica, no sentido que especifica a arquitetura dos componentes (ou primitivas) usadas em uma teoria de domínio particular. Pode-se dizer também que é a ontologia que especifica, para uma teoria que tem a forma de constantes matemáticas, o que é uma constante e como ela difere de uma fórmula de outro tipo. A ontologia seria como uma representação dos componentes e suas possíveis interações, com o propósito de prover uma estrutura para elaborar o resto do sistema.

Enquanto a ciência Ontologia ocupa-se com o estudo da organização de todas as coisas, ontologias são construídas para tentar-se organizar o conhecimento de áreas específicas, como 
as da Biologia ou da Química.

A palavra "ontologia", entretanto, geralmente é entendida como uma estrutura conceitual particular no nível semântico (interpretações 2 e 3) ou como um artefato concreto, no nível sintático, com propósitos determinados (interpretações 4 - 7). Apesar dos significados distintos, na prática o termo acaba sendo usado ambiguamente (GUARINO; GIARETTA, 1995).

Ao invés de usar somente um significado para o termo, Giaretta e Guarino propõem a adoção de diferentes condições para se referir explicitamente a cada um dos dois níveis, enquanto tolera-se uma certa ambigüidade do termo "ontologia". A conceituação é usada para denotar uma estrutura semântica referente a um sistema conceitual em particular (interpretação 3) e teoria de ontologia (ontological theory) para denotar uma teoria lógica que pretende expressar conhecimento ontológico (interpretação 5). A base destas afirmações, que teorias ontológicas são um artefato de projeto, é que bases de conhecimento podem ser lidas, vendidas ou fisicamente compartilhadas. Conceituações, por outro lado, são a contra-parte semântica das teorias ontológicas. A mesma teoria ontológica pode servir a diferentes conceituações, como uma mesma conceituação pode se basear em diferentes teorias ontológicas. Então o termo "ontologia" poderá ser usado ambiguamente, tanto como sinônimo de teoria ontológica, como sinônimo de conceituação. Só é preciso ser consistente à escolha que é feita dentro do mesmo texto. De 1 - 4 o termo "ontologia" tem uma interpretação sintática clara.

Então, o uso do termo "ontologia" como relacionado a uma teoria ontológica é compatível com (GUARINO; GIARETTA, 1995):

1. A engenharia de ontologias é um ramo da engenharia de conhecimento que usa Ontologia (da filosofia) para construir ontologias.

2. Ontologias são tipos especiais de bases de conhecimento.

3. Toda ontologia tem sua conceituação subjacente.

4. A mesma conceituação pode basear diferentes ontologias.

5. Duas bases de conhecimento diferentes podem compartilhar a mesma ontologia.

Já (GRUBER, 1993) define ontologia como "uma especificação explícita e formal de uma conceituação compartilhada". Porém, esta definição não é completa se não contemplar o 
significado de termos como "especificação explícita", "formal", "conceituação" e "compartilhada":

- especificação explícita: conceitos, propriedade, relações, funções, constantes e axiomas são definidos explicitamente;

- formal: que pode ser lido por máquina;

- conceituação: modelo abstrato de algum fenômeno do mundo;

- compartilhada: conhecimento consensual.

O problema com a definição de Gruber, entretanto, é que ela faz uso de uma extensão da noção de "conceituação" que, ao ser compatível com a caracterização preliminar dada anteriormente, não serve aos propósitos de definir o que uma ontologia é. É necessária uma definição intensional ${ }^{1}$ de "conceituação" que satisfaça a esta necessidade.

E qual o significado que a definição de Gruber: "uma ontologia é a especificação de uma conceituação" deve ter? É evidente que a terceira interpretação é incompatível com essa definição, e é melhor que não seja usado o termo "ontologia" em um senso semântico sem que isto esteja claro no contexto.

\subsubsection{O que não é uma ontologia?}

Uma ontologia não é uma coleção de fatos advindos de uma situação específica, mas ela provê todas as entidades semânticas (por exemplo: classes) para descrever essa situação. Uma ontologia não é um modelo de um domínio de aplicação, mas sim um compêndio de todos os blocos de construção com suas combinações para expressar uma teoria. Um modelo completo de um domínio de aplicação (por exemplo: química enzimática) seria um conjunto de hipóteses (possivelmente verificado) ou uma tẹia.

Uma ontologia não é um esquema de banco de dados, pois também pode descrever outros tipos de relações entre as entidades, não presentes num banco de dados relacional. Um

\footnotetext{
${ }^{1} \mathrm{Na}$ lógica extensional, a semântica de uma fómula é dada por uma interpretação que leva termos em subconjuntos do domínio e predicados em relações entre elementos do domínio. Já na lógica intensional, existe um outro argumento a ser levado em consideração, a semântica é dada por uma interpretação que varia com a situação.
} 
esquema de banco de dados pode ser derivado de uma ontologia pela adição da informação do tipo de dados, além das devidas alterações sintáticas. Um banco de dados também pode ser usado para inicialmente estabelecer conceitos ou povoar uma ontologia (SCHULZE-KREMER, 2002).

Uma ontologia não é uma base de conhecimento que coleciona apenas instâncias de objetos, a ontologia armazena uma coleção de tipos de objetos, eventos etc, usados para especificar aqueles objetos na situação em que se deseja representá-los.

Uma ontologia não é uma taxonomia que conhece apenas relações de super-classes e sub-classes, mas uma ontologia é aberta em muitos tipos de relacionamentos entre conceitos (por exemplo: topológicos, compositivas etc, como agregações, associações, dependências, extensões, realizações, relacionamentos de ordem). Pode-se dizer que uma substância é parte de um composto ou que uma reação depende de uma certa condição por exemplo.

Uma ontologia não é um vocabulário ou dicionário já que as palavras no dicionário não descrevem necessariamente a hierarquia e a relação entre cada conceito e não são organizadas de forma que suportem inferência computacional. Numa ontologia geralmente pode-se seguir um caminho de qualquer conceito para outro através das relações "é um" por exemplo, ou outras relações, já que comumente todas as classes de uma ontologia são derivadas de uma classe inicial, como "thing" ou "object" por exemplo.

Entretanto, como será mostrado nos próximos capítulos, muitos vocabulários controlados são chamados ontologias, como o Gene Ontology por exemplo.

\subsection{Ontologia do ponto de vista da bioinformática: ti- pos e aplicações}

A visão da Ciência da Computação sobre ontologia é a de um modelo de trabalho de entidades e interações genéricas quaisquer (por exemplo a ontologia $\mathrm{Cyc}^{2}$ ) ou mais especificamente em um domínio particular de uma área do conhecimento, como biologia molecular ou bioinformática. A seguinte definição pode ser dada:

"Uma ontologia pode assumir uma variedade de formas, mas necessariamente

\footnotetext{
${ }^{2}$ http://www.opencyc.org
} 
inclui um vocabulário de termos, e alguma especificação dos seus significados. Isto inclui definições e indicações de como os conceitos são inter-relacionados, o que impõe coletivamente uma estrutura ao domínio e limita as possibilidades de interpretação dos termos" (GRUBER, 1993).

Gruber define uma ontologia como uma "especificação de uma conceituação, usada para permitir que programas e pessoas compartilhem conhecimento". A conceituação é uma coleção de conhecimento sobre o mundo nos termos das entidades (coisas, as relações que carregam e o significado de seus termos). A especificação é a representação desta conceituação de uma forma concreta. Um passo nesta especificação é a codificação da conceituação numa linguagem de representação do conhecimento ${ }^{3}$. O objetivo é criar um vocabulário coerente e uma estrutura semântica para trocar informação sobre aquele domínio (STEVENS; GOBLE; BECHHOFER, 2000).

Mas do que se compõe uma ontologia? Os principais componentes de uma ontologia são conceitos, relacionamentos, instâncias e axiomas. Um conceito representa um conjunto ou classe de entidades ou "coisas" dentro de um domínio. Proteína é um conceito dentro do domínio da biologia molecular. Conceitos são classificados em dois tipos: conceitos primitivos e definidos. Conceitos primitivos são aqueles que possuem apenas as condições necessárias para serem membros da classe. Por exemplo, uma proteína globular é um tipo de proteína com um núcleo hidrófobo, então todas as proteínas globulares têm um núcleo hidrófobo, mas podem existir outras coisas que também tenham um núcleo hidrófobo que não sejam proteínas globulares. Conceitos definidos são aqueles em que sua descrição é ao mesmo tempo necessária e suficiente para que algo seja um membro da classe. Por exemplo, células eucarióticas são tipos de células que têm um núcleo. Não apenas todas as células eucarióticas têm um núcleo, mas cada célula que contém um núcleo é eucariótica.

Relações descrevem as interações entre conceitos ou entre propriedades dos conceitos. Relações na maioria dos casos são de um destes tipos: taxonomias, cujas formas mais comuns são relações de especialização, como em "uma enzima é um tipo de proteína" e relações de

\footnotetext{
${ }^{3}$ Uma Linguagem de Representação do Conhecimento é definida por:

- uma sintaxe, que descreve as configurações que podem constituir sentenças daquela linguagem;

- uma semântica, que liga cada sentença aos fatos no mundo que ela representa cada sentença faz uma afirmação a respeito do mundo.
}

E geralmente possuem um mecanismo de inferência associado. 
parte como em "proteínas têm o componente local da modificação".

Instâncias são casos particulares representados por um conceito: colágeno é uma instância do conceito proteína. Estritamente falando, uma ontologia não deve conter nenhuma instância, porque ela é supostamente uma conceituação do domínio. A combinação de uma ontologia com instâncias associadas é o que se chama base de conhecimento. Entretanto, decidir quando algo é um conceito ou uma instância é difícil, e freqüentemente depende da aplicação. Por exemplo, átomo é um conceito e potássio é uma instância deste conceito. Pode ser argumentado que potássio é um conceito que representa as diferentes instâncias de isótopos de potássio. Esta é uma questão bem conhecida e ainda aberta dentro da área de pesquisa de representação de conhecimento e também da área de orientação a objetos (SCHULZE-KREMER, 2002).

Os axiomas são usados para restringir valores das classes ou instâncias. Neste sentido, as propriedades dos relacionamentos são tipos de axiomas. Eles também incluem mais regras gerais, como "os ácidos nucléicos com menos de vinte resíduos são oligonucleotídeos" (STEVENS; GOBLE; BECHHOFER, 2000).

Ontologias são usadas em uma larga área de aplicações na biologia (STEVENS; GOBLE; BECHHOFER, 2000): como vocabulário comum para anotação da base de dados, facilitando a documentação, compreensão, manutenção e o compartilhamento; e para busca baseada em ontologia por perguntas (queries) em bancos de dados. Por exemplo, na busca em um bancos de dados por "DNA mitocondrial ligando proteínas em helicoidal dupla", apenas estas proteínas serão encontradas, pois termos exatos para procura foram usados. Apesar do usuário dos termos estar certo sobre seu significado, o conhecimento pode ter sido representado de outras formas, não favorecendo a pesquisas por termos exatos. Estas perguntas podem ainda ser refinadas acompanhando relacionamentos dentro da ontologia. Por exemplo, especializando "DNA ligando proteínas" para "helicoidal simples de DNA ligando proteínas" se a busca anterior trouxer respostas em demasia. Dois exemplos, integração e anotação de dados serão explicados.

Integração está envolvida com o problema da heterogeneidade semântica e sintática. A questão sintática é trivialmente resolvida por programas de reconhecimento de padrões, enquanto que a heterogeneidade semântica precisa de um repositório unificado para ser resolvida. Cada banco de dados, por exemplo, deve ser alinhado com a estrutura e o conteúdo de 
cada um dos outros bancos envolvidos. Já que o significado não é necessariamente simétrico quando mapeado para outro banco, no caso de $\mathrm{n}$ bancos de dados teria-se $n \times(n-1)$ possibilidades de integração. Entretanto, se conseguirmos colocar uma ontologia "no meio" desses $n$ bancos de dados, o esforço de integração seria reduzido para $n$ apenas, já que cada banco de dados deveria ser mapeado para essa ontologia. Um algoritmo poderia inferir os conceitos similares de qualquer banco para a ontologia e da ontologia para qualquer outro banco (SCHULZE-KREMER, 2002) (KöHLER; SCHULZE-KREMER, 2002). Para anotação de dados ${ }^{4}$, as vezes utiliza-se somente um vocabulário controlado, e não uma ontologia completa. Um vocabulário deste tipo será estudado no próximo capítulo.

Um ideal comum para uma ontologia é que ela deve ser reutilizável, isto a distingue de um banco de dados, mesmo ambos sendo conceituações. Entretanto, uma ontologia só é reutilizável para os mesmos propósitos a que foi desenvolvida. Como nem todas as ontologias têm o mesmo propósito, podem haver partes que não sejam reutilizáveis. Elas podem variar também em sua cobertura e nível de detalhe. Pode-se dividir as ontologias em três tipos (STEVENS; GOBLE; BECHHOFER, 2000): orientadas ao domínio, orientadas a tarefas e genéricas.

A maioria das bio-ontologias tem uma mistura destes três tipos de ontologia e quanto mais bem escritas, mais modulares e passíveis de reutilização. A medida de quão bem as dependências em uma ontologia foram separadas é conhecida como compromisso ontológico (ontological commitment). Outras medidas para a qualidade de uma ontologia incluem clareza, consistência, completude e concisão.

\footnotetext{
${ }^{4}$ Anotação de dados são informações extras associadas com uma entrada particular de um vocabulário. No Gene Ontology anotações são associações feitas entre os produtos genéticos e os termos GO que os descrevem.
} 


\section{$3 \quad$ Estudo de Algumas Bio-ontologias e Vocabulários Controlados}

O uso de ontologias dentro da bioinformática é relativamente recente, conseqüentemente não há um grande número em existência, entretanto, das ontologias existentes, uma parte significativa é de bio-ontologias. Nesta parte, uma amostra representativa de algumas bioontologias e vocabulários controlados existentes será mostrada. Este estudo foi restrito às ontologias e trabalhos mais pertinentes às tendências correntes em bioinformática e biologia molecular, ao invés de um largo campo da Biologia. A Biologia é rica em termos de taxonomias, como as classificações das enzimas e das espécies. Sendo taxonomias, elas apenas usam uma hierarquia simples. As ontologias e vocabulários estudados aqui tendem a ter muitos relacionamentos, entretanto eles são bastante simples, como sinônimos ou relações de pertinência simples como "é um". As ontologias e vocabulários controlados estudados são os seguintes:

- Gene Ontology (GO) ${ }^{1}$

- EcoCyc ontology ${ }^{2}$

- TAMBIS Ontology $(\mathrm{TaO})^{3}$

- RiboWeb ontology ${ }^{4}$

- BioPAX $^{5}$

\footnotetext{
${ }^{1}$ http://www.geneontology.org

${ }^{2}$ http://www.ecocyc.org

${ }^{3}$ http://img.cs.man.ac.uk/tambis

${ }^{4}$ http://smi-web.stanford.edu/projects/helix/riboweb.html

${ }^{5}$ http://www.biopax.org/
} 
Essas ontologias estão sendo usadas pelas comunidades de pesquisa para prover entrada de conhecimento a bancos de dados e aplicações. O propósito da ontologia influencia o conteúdo e a natureza do conhecimento capturado, já que dele depende a granularidade da captura do conhecimento por exemplo, e isto não é uma contradição das capacidades de armazenar conhecimento das ontologias. Não apenas o propósito determina o escopo e a granularidade para qual o mesmo conhecimento é representado em diferentes ontologias, mas também as conceituações do mesmo domínio podem ser diferentes sem estarem erradas. Por exemplo, o TaO descreve que o DNA deve ser traduzido para proteína. Isto está errado em termos de biologia molecular, mas é uma característica da bioinformática, então conceituações do mesmo domínio podem ser diferentes. Algumas vezes uma restrição é necessária para uma aplicação e em outras não é. Isto apenas muda qual conhecimento é capturado ou como ele é capturado, isto não muda o próprio conhecimento (STEVENS; GOBLE; BECHHOFER, 2000).

\subsection{Gene Ontology}

O Gene Ontology (GO), cuja notação e referência vem crescendo continuamente, tem a anotação da base de dados como seu objetivo principal. Ao invés de tentar descrever todo o conhecimento de biologia molecular, GO procura armazenar informação sobre regras de produção gênica dos organismos. GO foi inicialmente criado para refletir as funções genéticas na drosófila, através do banco de dados Flybase, mas foi expandido para abranger o banco de dadọs da expressão gênica de ratos, moscas, leveduras e minhocas, e espera-se que continue expandindo. GO não possui nenhuma ontologia de organização de alto-nível. Isso significa que não há qualquer critério de subclassificação específico. A posição de cada termo é definida pelo próprio consórcio. Assim, o objetivo principal do GO é um vocabulário controlado, para anotações conceituais, dos processos e da localização da função de produção gênica, em bancos de dados. Pode-se procurar por conceitos destes organismos em três classificações: função molecular, componente celular e processo biológico, representando a função da produção gênica e o processo no qual ela ocorre, além da localização celular e estrutura. GO contém um vasto campo de conceitos, e provê um rico nível de detalhe nas suas três hierarquias. São usados relacionamentos "é um tipo de" e "é uma parte de" para descrever as regras da produção genética. Já há mais de 5.000 conceitos na ontologia.

GO define um nível fino, de detalhe conceitual, por exemplo: DNA mitocondrial ligando 
proteínas em helicoidal dupla, fatores de transcrição, proteína de músculo motor, memória e aprendizado, coagulação sanguínea, morfogenética, formação do padrão ventral e muitos caminhos $^{6}$, transportes e sinais em vários sistemas. GO utiliza herança múltipla na relação "é um tipo de" para formar alguns de seus conceitos e há algum uso do relacionamento "é uma parte de". Muitas das relações capturadas pelos conceitos, entretanto, continuam implícitas no GO. Por exemplo, o conceito "succinate (cytosol) to fumarate (mitochondrion) transporter" implicitamente carrega propriedade e orientação sobre o local (citoplasma) na membrana mitocondrial (STEVENS; GOBLE; BECHHOFER, 2000).

Os vocabulários controlados permitem que um software explore as bases de dados genéticas e vincule genes relacionados entre si utilizando palavras que descrevem sistematicamente suas funções, independentemente de como se chamam os genes. Entretanto, devido à característica de um mesmo gene poder ter funções diferentes, uma nomenclatura por função que estaria correta hoje, quando da descoberta de outras funções de tal gene, pode não ser a mais correta. Entretanto, isso não impede o compartilhamento de conhecimento. Alguns pesquisadores defendem que não deve haver nomes, apenas números para se referir a um determinado gene.

O consórcio GO estabelece palavras para descrever as funções moleculares, os processos biológicos e os componentes celulares, podendo vincular genes relacionados, independentemente da nomenclatura. A cada gene e seus produtos, há um termo GO associado, muitas vezes, com sinônimos, já que os biólogos utilizam-se de vários termos para o mesmo processo, como divisão celular e citoquinese, por exemplo. O objetivo é construir uma base de dados plenamente consultável, que explique a função dos genes em todos os organismos. Devido a estas características, o GO está ganhando popularidade com rapidez. Em muitas ontologias estudadas durante este trabalho foram encontrados termos referindo o GO.

Entretanto, os princípios de projeto do GO não previnem todos os problemas (SCHULZEKREMER, 2002). No GO apesar de haver um bom detalhamento de relacionamentos, não há definições da maioria dos conceitos, o que não auxilia em sua compreensão. Não existe um princípio de projeto claro no GO, já que não há uma orientação de em que classe colocar cada conceito, pois não há qualquer critério de subclassificação específico para guiar a inclusão de novos termos dentro de cada uma das três distinções. Apesar das modificações serem

\footnotetext{
${ }^{6}$ Para uma visualização do caminho metabólico da glicólise, consulte "Metabolic Pathways of Biochemistry: Glycolysis" de Karl J. Miller, disponível em http://www.gwu.edu/ mpb/glycolysis.htm
} 
realizadas somente após a aprovação do consórcio, nada garante a consistência e a corretude do GO após cada adição de novos conceitos.

As três distinções do GO citadas anteriormente (função molecular, componente celular e processo biológico), funcionam não como uma ontologia, mas sim como três ontologias, já que estas hierarquias não são ligadas entre si, e aparentam não estarem relacionadas. Atualmente, o GO ainda é mais uma nomenclatura controlada para biologia molecular do que uma ontologia genética completa. O GO é distribuído no formato RDF XML e como um banco de dados MySQL.

\subsection{EcoCyc}

Ecocyc é uma "enciclopédia dos genes e metabolismo da Escherichia coli". Na EcoCyc, uma ontologia é usada para descrever a riqueza e complexidade de um domínio e as restrições que agem com este domínio (os genes do E. coli) para especificar um esquema de banco de dados. A apresentação usa uma metáfora de enciclopédia. Ela cobre os genes, o metabolismo e caminhos metabólicos, regulação e transdução de sinais, por exemplo os quais os biólogos podem explorar, visualizando as informações. O banco de dados descreve atualmente 4402 genes, 944 enzimas codificadas por subconjuntos destes genes, 990 reações enzimáticas e 177 reações de transporte, organizadas em 173 caminhos metabólicos. EcoCyc usa a classificação das funções do gene por Riley (M. RILEY, 1993) como parte de sua descrição. Os cientistas podem visualizar os genes dos cromossomos do $E$. coli, ou uma reação bioquímica individual, ou ainda um caminho metabólico com as estruturas dos componentes.

A visualização ${ }^{7}$ e comparação de caminhos metabólicos são especialmente importantes na biologia, pois através da observação de caminhos metabólicos de seres semelhantes, os biólogos podem inferir as reações bioquímicas dos organismos que estão sendo pesquisados ${ }^{8}$.

O EcoCyc usa uma ontologia para definir um esquema de banco de dados com a vantagem da expressividade e da habilidade para levar em conta mudanças necessárias para acomodar a informação biológica. Desta forma o uso da ontologia é transparente para o usuário, de

\footnotetext{
${ }^{7}$ Para um exemplo de visualização, consulte o "Step by Step Glycolisys", de Jon Maber, disponível em http://www.jonmaber.demon.co.uk/glysteps/

${ }^{8}$ Essa comparação se dá por observação no caso do EcoCyc ou é feita com o uso de ferramentas para isto, como o BioMiner (SIRAVA et al., 2002), que atualmente só utiliza o KEGG (Kioto Encyclopedia of Genes and Genomes) (KANEHISA et al., 2004), entretanto há planos para usar outras ontologias, como o EcoCyc.
} 
forma que o significado do conhecimento se mantenha preciso. No EcoCyc, por exemplo, o conceito de gene é representado por uma classe com vários atributos, ligados a outros conceitos como: produto polipeptídico, nome do gene, sinônimos e identificadores usados em outros repositórios, como o GO. O sistema de representação, que usa os formatos BioPAX e SBML, pode ser usado para impor restrições nestes conceitos, e instâncias podem aparecer em lugares descritos pelo sistema (SCHULZE-KREMER, 2002).

\subsection{TAMBIS}

O objetivo do projeto TAMBIS é ajudar pesquisadores de ciências biológicas provendo um único local para acesso de informações biológicas. Apesar de acessar dados de diferentes repositórios, que os tratam de forma diferente, as respostas são processadas de uma forma consistente, para que o usuário tenha a impressão de estar consultando apenas uma ontologia. As questões dos usuários são procuradas nas fontes apropriadas (externas) e depois de processadas são devolvidas com detalhes sobre as fontes de informação.

TAMBIS tenta prover consultas transparentes e filtragem de informações de cunho biológico. Para fazer isto, existe uma camada de homogeneização, no topo das fontes. Esta camada usa mediadores e envoltórios para criar a ilusão de uma única fonte de dados. O projeto TAMBIS foi criado para ajudar a tarefa de obter e comparar seqüências e outras informações heterogêneas, já que são processos que demandam grande esforço manual, retardando o progresso das pesquisas.

Existem mais de 200 fontes de informações biológicas, cada uma delas repletas de dados, mas que só são úteis para seus próprios mecanismos. Existem três tipos principais dessas fontes:

- bancos de dados;

- serviços on-line;

- arquivos.

Em um cenário típico sem o TAMBIS, o usuário deveria fazer questões para cada tipo de sistema, como SQL para os bancos de dados e buscas nos arquivos. O usuário deveria também 
interpretar as respostas recebidas das diferentes fontes, e ainda assim não tem uma visão geral. Isto significa que muito tempo é gasto selecionando-se a fonte apropriada, elaborando a questão e interpretando as respostas, levando à sub-utilização destes recursos. É nessa parte que o uso do TAMBIS ajuda os pesquisadores, por funcionar como uma única interface para todos os recursos e por dar a ilusão de um único recurso (BAKER et al., 1998).

Esse funcionamento se dá através de uma ontologia de referência, chamada BioCon, escrita em DAML+OIL. Essa ontologia é usada para: descrever meta-dados que baseiam as fontes de consultas, formular questões na linguagem de modelagem, dirigir uma interface gráfica para a formulação das questões, já que os usuários não estão preparados para escrever questões complexas e intermediar as várias fontes para tradução do modelo do mediador para o modelo das fontes. A mediação explora a BioCon para ajudar a identificar e resolver equivalências ou quase equivalências nas fontes de informação.

Como citado anteriormente, há um mediador, que é um corretor de informações, e vários envoltórios. O mediador envia as consultas realizadas nesta ontologia para cada envoltório de cada ontologia utilizada nas bases de consulta, e depois recebe as respostas e os resultados obtidos são transcritos de volta nesta ontologia de referência.

\subsection{RiboWeb}

O objetivo do RiboWeb é a construção de modelos tridimensionais dos componentes do ribossomos e a comparação dos resultados com os estudos existentes. O conhecimento usado pelo RiboWeb para realizar suas tarefas é capturado em quatro ontologias: Coisa-física (Physical-thing); Informações (Data); Publicações (Publication) e Métodos (Methods), em XML.

A ontologia da Coisa-física descreve os componentes e associações físicas dos ribossomos. Há aqui três princípios de conceituação: moléculas, moléculas-construídas e partes-demolécula. O primeiro princípio descreve moléculas ligadas por covalência e inclui a maior parte das macromoléculas biológicas. O segundo captura as coleções de moléculas ligadas por outras formas, como complexos enzimáticos. O terceiro guarda conhecimento sobre regiões de moléculas que não existem independentemente, mas precisam ser conhecidas por conterem certas propriedades específicas. Este último tipo inclui cadeias de amino-ácido e os finais de algumas moléculas de ácido nucléico. A ontologia de Informações captura conhecimento 
sobre detalhes experimentais bem como dados da estrutura das coisas físicas. A ontologia de Publicações informa as fontes de referência dos conceitos. A ontologia de Métodos contém informação sobre técnicas para analisar a informação. Ela guarda conhecimento de qual a técnica que pode ser aplicada em qual informação, bem como as entradas e saídas de cada método.

Instâncias são adicionadas ao RiboWeb na correspondência destes conceitos. Por exemplo, um artigo de uma publicação descreve uma estrutura tridimensional de 30 subunidades ribossômicas. Isto significa que instâncias precisam ser criadas e ligadas nas ontologias de publicação, informação e coisas-físicas. Um usuário pode querer visualizar se essa estrutura é consistente com as outras pertinentes ao RiboWeb. RiboWeb pode então mostrar conflitos com o conhecimento corrente do biólogo (SCHULZE-KREMER, 2002). A linguagem adotada para guardar o conhecimento é XML.

\subsection{BioPAX}

BioPAX é um esforço colaborativo para criar um formato de troca de dados para informações de caminhos metabólicos. Atualmente, há cerca de 190 bancos de dados acessíveis pela Internet que guardam informações sobre caminhos metabólicos (BADER; CARY, 2005). Biólogos geralmente necessitam usar informações de várias deles em suas pesquisas, mas já que cada um tem suas próprias convenções de representação e métodos de acesso, integrar data de múltiplos bancos de dados é bastante difícil. Um formato de troca de dados de caminhos metabólicos largamente adotado ajudaria nessa tarefa. Éssa é a motivação da construção do BioPAX.

O BioPAX (Biological Pathway Exchange) permite a integração de diversos recursos pela definição de uma especificação de formato aberto para a troca de dados sobre caminhos metabólicos. Pelo uso do formato BioPAX, o problema de integração de dados se reduz a um mapeamento semântico entre os modelos de dados de cada recurso e os modelos de dados definidos pelo BioPAX. A larga adoção do BioPAX para troca de dados aumentará o acesso e a uniformidade dos dados de diversas fontes, aumentando assim a eficiência de pesquisas computacionais sobre os caminhos metabólicos. O BioPAX faz uso da linguagem OWL para armazenar sua ontologia. 


\section{Ferramentas para a descrição de ontologias}

A escolha da linguagem em que será descrita a ontologia é um dos passos mais importantes de sua construção, já que o seu poder de expressão determina que conhecimentos pode-se capturar. Como as ontologias evoluem ao longo do tempo, de acordo com as novas descobertas e novos conhecimentos, o uso de ferramentas é útil para ajudar o mapeamento das transformações do conhecimento. Um grande número de linguagens pode ser usado, incluindo linguagens de programação em lógica como o Prolog. Entretanto é mais comum que se use linguagens desenvolvidas especificamente para a construção de ontologias (DENNY, 2004). O protocolo OKBC (CHAUDHRI et al., 1998) e linguagens como KIF (GRUNINGER, 2001) ou Common Logic (COMMON LOGIC WORKING GROUP, 2003) são exemplos que se tornaram bases para a construção de outras linguagens. Existem também muitas linguagens baseadas em lógica de forma a facilitar o processamento por computadores, conhecida como lógica de descrição (description logics). Exemplos incluem o PowerLoom (mas não restrito a ela) e o OWL. A grande quantidade de informações disponíveis na Internet tem também dado incentivo à pesquisa de ontologias para organizar conteúdo, como o OWL. Uma linguagem de descrição de conhecimento precisa ser rica e expressiva tanto quanto as nuanças e as características do conhecimento que ela captura (DENNY, 2004). Nas próximas seções será estudado um protocolo, OKBC e as seguintes linguagens: XML, OWL e LOOM / PowerLoom.

Grande parte das ontologias atuais é criada com o uso de editores de ontologia, que permitem navegação, codificação e modificação na ontologia, de forma a facilitar sua construção e manutenção, já que estão ligadas ao mundo real, em ambientes mutáveis (STOJANOVIC; MOTIK, 2002). Os editores existentes variam, por exemplo, na complexidade do modelo de conhecimento, na usabilidade e na escalabilidade. Então, quando inicia-se um projeto de 
construção de ontologias, um dos primeiros passos pode ser encontrar um editor de ontologias apropriado (JONES; BENCH-CAPON; VISSER, 2002).

Como a modificação de um conceito pode gerar inconsistências em outras partes de uma ontologia, muitas vezes se faz necessário o uso de ferramentas de software para facilitar essas tarefas. Além disto, a evolução das ontologias está se tornando mais importante a cada dia. O principal motivo é o alto custo associado das adaptações dos requisitos que se modificam ao longo do tempo. O desenvolvimento de ontologias e suas aplicações são caros, mas modificá-los é ainda mais custoso. Nas seções seguintes, serão apresentados quatro editores: Protégé, que usa OKBC e OWL; SysmOntoX, que usa XML e Ontosaurus, que usa LOOM e PowerLoom.

Há ainda outros tipos de ferramentas que cobrem outros aspectos do desenvolvimento de uma ontologia. Alguns projetos desenvolvem soluções que usam várias outras ontologias como fontes externas. Nestes casos, são úteis ferramentas para realizar combinações e conversões entre formatos (DENNY, 2004). Outras ferramentas podem ainda ajudar a adquirir, capturar e visualizar os conhecimentos do domínio, antes e durante a construção da ontologia, como os plugins do Protégé por exemplo.

\subsection{Protocolos e Linguagens para descrição de ontolo- gias}

Antes da apresentação das linguagens para descrição de ontologias, é necessário o conhecimento prévio de alguns termos:

- $\mathrm{KIF}^{1}$ é o acrônimo de formato de troca de conhecimento (Knowledge Interchange Format) e foi uma das primeiras linguagens de compartilhamento de conhecimento. É uma linguagem formal, que contém semântica declarativa (o significado da expressão representada pode ser entendido sem o uso de um interpretador para manipular esta expressão). KIF é logicamente compreensível, isto é, ele provê para a expressão de sentenças arbitrárias um cálculo de predicados em lógica de primeira ordem. Ele provê regras de raciocínio não-monotônicas para a representação do conhecimento e definição de objetos, funções e relações (RIBIÈRE; CHARLTON, 2001).

\footnotetext{
${ }^{1}$ http://Logic.Stanford.EDU/kif/
} 
- Lógicas de descrição² (NARDI; BRACHMAN, 2002) (description logics) são uma forma especializada de lógica usada para descrever conhecimento em termos de conceitos e regras de restrições que podem ser usadas para automaticamente derivar hierarquias de classificação. Alguns exemplos de sistemas e linguagens que são baseados em lógicas de descrição são KL-ONE, Loom e OWL. Estes sistemas têm relacionamentos e funções que são entidades separadas dos conceitos. Lógicas de descrição permitem a definição de classes em termos da descrição que especifica as propriedades satisfazíveis pelos objetos pertencentes ao conceito. Lógicas deste tipo, em geral, provêm formadores de operadores de conceitos que podem ser usados nessas descrições, incluindo conjunção, disjunção, negação e várias formas de regras de quantificação. Um aspecto chave das lógicas de descrição é sua semântica formal e suporte ao raciocínio. Lógicas de descrição definem fragmentos de lógica de primeira ordem que em geral tem alta expressividade mas que ainda assim são decidíveis e eficientes em procedimentos de inferência.

Lógicas de descrição são difíceis de serem tratadas diretamente. No passado, elas foram concebidas como grandes sistemas monolíticos que requeriam que o usuário construísse seus modelos diretamente em sua sintaxe (BECHHOFER; GOBLE; HORROCKS, 2001). Sistemas baseados em lógica de descrição possuem maneiras para construir descrições baseadas na estrutura dos conceitos e relacionamentos. Por exemplo, pode-se escrever um conceito como:

Parent $=$ Person and at-least 1 child

e o sistema ser capaz de representar e manipular isto. A lógica de descrição é intencionalmente restrita em seu poder de expressividade, para que algoritmos tratáveis (e algumas vezes completos) possam ser executados. Protégé, por exemplo, também tem uma interface OWL, então ele pode ser usado para criar e editar bases de conhecimento baseadas em lógicas de descrição.

- Lógicas de primeira ordem ou cálculos de predicado de primeira ordem são bastante expressivas, e não permitem que uma máquina de inferência tratável e completa seja construída. Um exemplo de linguagem baseada em lógica de primeira ordem seria o KIF, que é a base para a representação de conhecimento do PowerLoom. O PowerLoom provê uma linguagem bastante expressiva de forma que se possa especificar o significado do domínio, com a adição de mecanismos e procedimentos de inferência para permiti-

${ }^{2}$ Para um tutorial, consulte: http://www.cs.man.ac.uk/ franconi/dl/course/ 
rem sua manipulação. Isto permite que se expressem certos conceitos que não seriam possíveis em uma linguagem típica de descrição lógica, como:

Pessoas com mais filhos do que filhas.

PowerLoom tem necessariamente um classificador de conceitos incompleto, bem como faz uso de encadeamento direto e reverso em seu mecanismo de inferência. A ele são também adicionados outros mecanismos de inferência especializados (CHALUPSKY; MACGREGOR; RUSS, 2003). O mecanismo de inferência do PowerLoom será estudado mais adiante.

- Sistemas baseados em quadros (frame systems). Este é um sistema de representação que usa termos como aberturas (slots), facetas (facets) e restrições. A organização é por classes. Propriedades podem pertencer a classes e ter restrições. Protégé ${ }^{3}$ foi inicialmente baseado em uma linguagem baseada em quadros, apesar de ter evoluído se tornando um editor gráfico que pode suportar vários conceitos de sistemas de representação. Quadros são o mais próximo de sua organização nativa, mas existem plugins que permitem seu uso em outros sistemas, como lógicas de descrição ${ }^{4}$.

Nas seções seguintes, serão mostrados o protocolo OKBC e as linguagens SymOntos, OWL e LOOM / PowerLoom, que são as linguagens que possuem o maior número de bioontologias escritas.

\subsubsection{OKBC}

OKBC é um acrônimo de Open Knowledge Base Connectivity, conhecido previamente como Protocolo de Quadro Genérico (Generic Frame Protocol) (CHAUDHRI et al., 1997). Ele especifica um protocolo, não uma linguagem. O protocolo trabalha sobre um sistema de representação de conhecimento, e é complementar às especificações da linguagem desenvolvidas para suportar o compartilhamento do conhecimento.

O modelo de conhecimento GFP que é o formalismo de representação implícita no qual se baseia OKBC, provê uma representação do conhecimento centrada no objeto e suporta

\footnotetext{
${ }^{3}$ Mais adiante, na seção de Editores de Ontologias, há mais informações sobre o Protégé.

${ }^{4}$ Para um estudo da evolução do Protégé, consultar "The Evolution of Protégé: An Environment for Knowledge-Based Systems Development" em http://smi.stanford.edu/pubs/SMI_Abstracts/SMI-20020943.html
} 
uma coleção de construtores de representação comumente encontrados em sistemas de representação de quadros: constantes, quadros, aberturas (slots), facetas, classes etc. Ele também define uma interface completa do tipo conte\&pergunte (tell\&ask) para as bases de conhecimento acessadas usando-se o protocolo OKBC e procedimentos (com uma sintaxe parecida com a do Lisp) para descrever operações complexas a fim de prover acesso às bases de conhecimento quando acessadas através de uma rede (CORCHO; GÓMEZ-PÉREZ, 2000). Existem implementações OKBC para diversas linguagens, incluindo Java, C e Common Lisp.

\subsubsection{XML}

XML é o acrônimo de eXtended Markup Language, derivado do SGML, Standard General Markup Language. Ele foi desenvolvido pelo XML Working Group do World Wide Web Consortium, o W3C, e é um padrão descrito em (BRAY et al., 2004).

Como outras linguagens para a Web, suas principais vantagem são a facilidade de análise gramatical sintática por computador já que sua sintaxe é bem definida e a possibilidade de ser lida por pessoas. Existem muitas ferramentas de software para análise sintática e manipulação de XML. XML permite aos usuários a definição de suas próprias etiquetas (tags) e atributos, definição das estruturas de dados (aninhando-os), extração de dados de documentos e desenvolvimento de aplicações que testam a validade estrutural de um documento XML.

Quando XLM é usado como a base para a especificação da linguagem da ontologia, tem-se as seguintes características: a definição de uma especificação sintática comum por meio de um DTD (Document Type Definition); pode ser usada para representar conhecimento distribuído através de várias páginas web, já que pode estar embutido nelas. Porém, há também algumas desvantagens, que influenciam a especificação da ontologia: a falta de informações dentro dos rótulos torna difícil a localização de componentes dentro de um documento, e ferramentas padrão são disponíveis para a análise sintática e a manipulação de documentos XML, mas não para se fazer inferências. Estas ferramentas devem ser criadas para que se possa fazer inferências com linguagens que são baseadas em XML.

XML propriamente dito não possui características especiais para a especificação de ontologias, já que ele apenas oferece um simples, mas potente modo de se especificar uma sintaxe para uma linguagem de especificação de ontologias. Entretanto, pode ser usado para cobrir 
necessidades de compartilhamento de ontologias, explorando as facilidades de comunicação da world wide web (CORCHO; GÓMEZ-PÉREZ, 2000).

Exemplo de XML:

$<$ classe $>$ Proteina

$<$ subclasse-de>Substancia</subclasse-de>

<comentario>Cadeia de centenas ou milhares de amino-ácidos.</comentario>

$</$ classe $>$

\subsubsection{RDF / RDF-S}

RDF é uma infraestrutura que permite a codificação, troca e reuso de metadados estruturados. RDF é uma aplicação de XML que impõe restrições estruturais necessárias para prover métodos de expressão semântica não ambígüos. RDF provê adicionalmente um meio de publicar vocabulários, que podem ser lidos tanto por humanos como processados por software. Esses vocabulários são planejados para encorajar o reuso e a extensão dos metadados semânticos entre comunidades de informação. As restrições estruturais impostas, permitem a condificação consistente e a troca de metadados padronizados, providos para o intercâmbio de pacotes separados de metadados, definidos pelas diferentes comunidades de descrição de recursos.

RDF-S ou RDF Schema é uma linguagem para descrever vocabulários em RDF. RDF Schema é uma extensão semântica do RDF. Ele provê um mecanismo para descrever grupos de recursos relacionados e as relações entre esses recursos. As descrições de vocabulário RDFS são escritas em RDF usando os termos descritos na especificação do RDF-S. Esses recursos são usados para determinar características de outros recursos, como domínios e escopos de propriedades.

\subsubsection{OWL}

OWL é uma linguagem de marcação semântica para publicação e compartilhamento de ontologias na Web. Assim como XML, OWL também é um padrão do W3C ${ }^{5}$. OWL ou Web Ontology Language foi planejada para ser usada quando a informação contida em

\footnotetext{
${ }^{5} \mathrm{O}$ padrão OWL está descrito em: http://www.w3.org/TR/owl-features/
} 
documentos necessita ser processada por aplicações, em oposição à situação onde o conteúdo precisa ser apresentado somente para humanos. Isso quer dizer apenas que é mais difícil ler OWL diretamente (sem o uso de ferramentas) do que PowerLoom por exemplo. OWL pode ser usada para representar explicitamente o significado de termos em vocabulários e os relacionamentos entre estes termos. Essa representação de termos e seus interelacionamentos é a constituição da ontologia. OWL é desenvolvido como uma extensão do vocabulário do RDF (Resource Description Framework). OWL tem mais facilidades para se expressar significado e semântica do que XML, RDF ${ }^{6}$ e RDF-S, já que OWL tem melhor habilidade de representar conteúdo interpretável automaticamente na Web, provendo um vocabulário adicional junto com a semântica formal. OWL é uma revisão da linguagem de ontologia DAML+OIL ${ }^{7}$ que incorpora o conhecimento e a experiência obtidos nos projetos DAML e OIL. OWL tem três sublinguagens, com seu poder de expressão em ordem crescente: OWL Lite, OWL DL e OWL Full. De acordo com (MCGUIMMESS; HARMELEN, 2004):

- OWL Lite dá suporte a usuários que necessitam primeiramente uma hierarquia de classificação e características simples de restrições. Por exemplo, enquanto OWL DL suporta restrições de cardinalidade, Lite permite somente valores de cardinalidade 0 ou 1. É mais simples fornecer ferramentas de suporte para OWL Lite do que para as outras sublinguagens de OWL, e fornece um trajeto rápido de migração para enciclopédias e outras taxonomias.

- OWL DL suporta aqueles usuários que querem a máxima expressividade sem perder a completude computacional (todas as expressões são garantidamente computáveis) e a decidibilidade (todas as computações serão terminadas em tempo finito) do mecanismo de inferência. OWL DL inclui todas as construções da linguagem, com restrições como separação de tipos (uma classe não pode ser também um indivíduo ou propriedade, uma propriedade não pode ser também um indivíduo ou classe). OWL DL é assim nomeado devido a sua correspondência com a Lógica de Descrição.

- OWL Full é indicado para usuários que queiram a máxima expressividade e a liberdade sintática de RDF, abdicando das garantias computacionais. Por exemplo, em OWL Full uma classe pode ser tratada simultaneamente como um coleção de indivíduos e como um indivíduo por si só. Uma outra diferença significativa de OWL DL é que pode-se marcar

\footnotetext{
${ }^{6} \mathrm{RDF}$ é um padrão do W3C descrito em http://www.w3.org/RDF/

${ }^{7}$ http://www.daml.org/
} 
uma propriedade de dados (owl : DatatypeProperty) como uma propriedade funcional inversa (owl: InverseFunctionalProperty). Isso significa que se uma propriedade assim marcada tiver duas instâncias com o mesmo valor, pode-se inferir que elas são idênticas. OWL Full permite que uma ontologia expanda o significado do vocabulário (RDF ou OWL) predefinido. É improvável que um mecanismo de inferência possa suportar todas as características de OWL Full.

Cada uma dessas sublinguagens é uma extensão de seus precessores mais simples, sendo que uma conclusão válida em uma sublinguagem mais simples continua sendo válida na mais complexa (MCGUIMMESS; HARMELEN, 2004):

- Toda ontologia OWL Lite válida é uma ontologia OWL DL válida;

- Toda ontologia OWL DL válida é uma ontologia OWL Full válida;

- Toda conclusão válida OWL Lite é uma conclusão OWL DL válida;

- Toda conclusão válida OWL DL é uma conclusão OWL Full válida.

Desenvolvedores de ontologias que adotam OWL devem considerar qual sublinguagem melhor se adapta às suas necessidades. A escolha entre OWL Lite e OWL DL depende da extensão com a qual esses usuários requerem mais expressividade provida por OWL DL. Mecanismos de inferência para OWL Lite tem propriedades computacionais mais desejáveis. Os mecanismos para OWL DL, como tratam com uma linguagem decidível, estarão sujeitos a uma complexidade maior no pior caso. A escolha entre OWL DL e OWL Full depende principalmente da extensão com que os usuários requerem as facilidade do meta-modelo de RDF Schema, por exexmplo, definir classes de classes.

Um exemplo do conceito de lipídio em OWL:

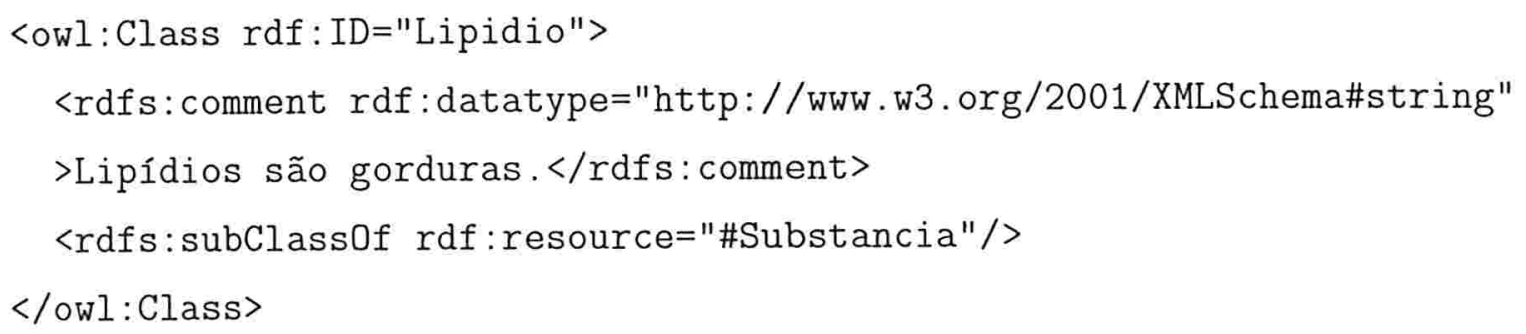




\subsubsection{LOOM e PowerLoom}

$\mathrm{LOOM}^{8}$ é uma linguagem de programação de alto nível e um ambiente, para uso na construção de sistemas especialistas e outros programas de aplicação inteligentes. Ele é um descendente da família de linguagens baseadas em quadros KL-ONE ${ }^{9}$ e é baseado em lógica de descrição, obtendo uma grande integração entre os paradigmas baseado em regras e baseado em quadros.

LOOM suporta uma linguagem de descrição para modelagem de objetos e seus relacionamentos, e uma linguagem de afirmações (assertions) para a especificação de constantes ou conceitos e relacionamentos, e para afirmar fatos sobre indivíduos. Programação procedimental é suportada através de métodos direcionados a padrões, enquanto as capacidades de inferência baseadas em produção e classificação suportam um poderoso mecanismo de raciocínio, na forma de um motor de inferência, o classificador.

É importante focar na abordagem da lógica de descrição para modelagem de ontologias, que se diferencia da abordagem baseada em quadros. Definições escritas usando esta abordagem tentam explorar a existência de um poderoso classificador na linguagem, como no PowerLoom, especificando conceitos pelo uso de um conjunto de restrições (CORCHO; GÓMEZ-PÉREZ, 2000).

PowerLoom ${ }^{10}$ é o sucessor da linguagem de representação de conhecimento LOOM. PowerLoom usa uma linguagem de representação baseada em lógica bastante expressiva (uma variante do KIF), e usa como motor de inferência um estilo de dedução natural com encadeamento direto e reverso (forward and backward chaining). PowerLoom tem um classificador que pode operar descrições expressas em lógicas de cálculo de predicados de primeira ordem. O motor de inferência não é um provador de teoremas completo de primeira ordem, mas ele pode manusear regras complexas, negações, raciocínio com igualdade, e formas restritas de raciocínio acima da lógica de primeira ordem. PowerLoom usa módulos como dispositivos estruturais para bases de conhecimento, e ambientes para suportar raciocínio hipotético.

Na implementação do PowerLoom, foi criada uma nova linguagem de programação chamada STELLA (Strongly Typed, Lisp-like Language). Ela pode ser traduzida em Lisp, C++

\footnotetext{
${ }^{8}$ http://www.isi.edu/isd/LOOM/LOOM-HOME.html

${ }^{9}$ Uma apresentação do KL-ONE é feita em: "An Overview of the KL-ONE Knowledge Representation System", R.J. Brachman and J. Schmolze, Cognitive Sci 9(2), 1985.

${ }^{10} \mathrm{http}: / /$ www.isi.edu/isd/LOOM/PowerLoom/
} 
e Java. PowerLoom é escrito em STELLA e está disponível em versões Lisp, C++ e Java. PowerLoom está sendo desenvolvido na Divisão de Sistemas Inteligentes da USC Information Sciences Institute.

Nas próximas partes da pesquisa, a linguagem LOOM/PowerLoom será comparada com OWL, e será proposta uma ontologia da área de bioquímica em ambas as linguagens.

Para ilustrar o funcionamento do PowerLoom, vamos fazer uso de alguns conceitos simples de Bioquímica. Inicialmente poderíamos definir a classe das proteínas:

$I=$ (def concept PROTEINA (?p)

:documentation "Proteínas são um componente essencial ao organismo.")

O comando acima, defconcept serve para definir um conceito, no caso proteína. A palavra-chave : documentation é utilizada para documentar esse conceito. Entretanto, algumas proteínas têm uma função especial, agindo como catalisadoras de certas reações químicas. Elas são as enzimas:

$I=$ (defconcept ENZIMA (?p PROTEINA)

:documentation "Enzimas são proteínas que aceleram reações químicas.")

Existem também as proteínas transportadoras, que são as carreadoras e as canal (PowerLoom não faz distinção entre maiúsculas e minúsculas):

$I=$ (def concept TIPOTRANSPORTADORA (?t)

:documentation "Tipos das proteínas transportadoras")

I= (assert (TipoTransportadora CARREADORAS))

$I=$ (assert (TipoTransportadora CANAL))

Uma substância só é uma proteína transportadora se não for uma enzima:

$I=$ (def concept TRANSPORTADORA (?p PROTEINA)

:documentation "Proteínas transportadoras transportam outros elementos."

$:=>($ and (Proteina ?p) (not (Enzima ?p)))) 
$\mid=($ deffunction TIPOTP ((?p TRANSPORTADORA)) :-> (?t TIPOTRANSPORTADORA) :documentation "Tipo da proteína transportadora.")

Algumas instâncias de proteínas:

$I=$ (assert (Proteina Aducina))

$\mid=$ (assert (Enzima Glucose-6-fosfatase))

$I=$ (assert (proteina ALBUMINA))

$\mid=$ (assert (enzima LACTASE))

$\mid=$ (assert (transportadora TRANSFERRINA))

$I=$ (assert (transportadora FRUCTOSA))

$I=$ (assert (= (tipotp TRANSFERRINA) carreadora))

$I=($ assert $(=($ tipotp FRUCTOSA $)$ canal $))$

Vamos consultar nosso conhecimento sobre as proteínas:

I= (retrieve all ( $p$ p TRANSPORTADORA)

(TRANSFERRINA FRUCTOSA)

$I=$ (ask (proteina transferrina))

(TRUE)

$I=$ (ask (transportadora transferrina))

(TRUE)

$I=$ (retrieve all (?p PROTEINA))

(ADUCINA GLICOSE-6-FOSFATASE ALBUMINA LACTASE TRANSFERRINA FRUCTOSA)

$I=$ (retrieve all (?p ENZIMA))

(LACTASE)

Agora vamos perguntar se a glucose-6-fosfatase que definimos como enzima, também é uma proteína:

$I=($ ask (Proteina Glucose-6-fosfatase)) 
Neste ponto podemos observar que a enzima é corretamente exibida também como proteína.

\subsection{Editores de Ontologias}

Como já foi dito, editores de ontologia são ferramentas que proporcionam navegação, codificação e modificações de forma a facilitar as tarefas de construção e manutenção de ontologias. Há vários tipos de editores, desde os gerais até os específicos, como referências de termos da área médica por exemplo. Nos primeiros editores de ontologias o foco era principalmente a aquisição do conhecimento, e isto influenciou algumas características dos editores de ontologias de então. Muitos deles adotaram como modelo o KADS ${ }^{11}$. Entretanto, esta orientação não é evidente nas ferramentas de hoje em dia (DENNY, 2004).

A proposta de uso de uma ontologia é servir como um ponto de troca e interpretação de informações. Quanto mais aplicações e outras ontologias utilizarem uma determinada ontologia, maior é a utilidade desta e das ontologias inter-relacionadas. Isto requer compatibilidade em níveis sintáticos, bem como semânticos. A interoperabilidade, ao invés disto, está sendo implementada simplesmente pela importação e exportação de ontologias em diferentes linguagens/serializações. Algumas ferramentas oferecem um grande escopo de conversões, porém a maioria tem limitações. Importar ou exportar ontologias geralmente significa traduções parciais e alguma expressividade perdida. Alguns poucos editores oferecem capacidades de combinação entre ontologias de um mesmo tipo.

Em adição as características já mencionadas, os editores de ontologia variam consideravelmente em sua apresentação geral ao usuário. Em termos de interfaces com outros sistemas de informação, o Protégé, que será estudado na próxima sessão, é um dos mais completos. Tratando-se da linguagem, o Ontolingua ${ }^{12}$ e o OpenCyc oferecerem ambientes de desenvolvimento com grande poder de expressão. OpenCyc também provê acesso nativo a parte de uma das maiores e mais completas ontologias disponíveis, a Cyc.

\footnotetext{
${ }^{11}$ O KADS é uma metodologia utilizada para desenvolvimento de sistemas baseados em conhecimento. Em muitas formas o KADS se assemelha à metodologia de software convencional, prescrevendo fases, modelos, documentos, provendo técnicas especializadas, métricas de projeto e procedimentos de garantia de qualidade para desenvolvimento de sistemas, diferenciando de outras metodologias pela atenção dada às características especiais dos sistemas baseados em conhecimento e aos problemas inerentes ao seu desenvolvimento (SCHREIBER; WIELINGA; BREUKER, 1993).

${ }^{12} \mathrm{http}: / /$ www.ksl.stanford.edu/software/ontolingua/
} 
As habilidades de organizar e gerenciar uma ontologia são pontos chave de usabilidade em um editor de ontologias. Já que muitos modelos de ontologias suportam herança múltipla, a abordagem padrão é o uso de múltiplas visualizações em árvore, e algumas vezes, uma representação em grafo.

Finalmente, vale a pena considerar o suporte a inferência contido nos editores de ontologia. Enquanto ontologias podem ser tratadas como especificações únicas, elas geralmente são usadas para responder perguntas sobre um corpo de informações (DENNY, 2004).

Neste capítulo, serão descritos alguns editores de ontologias, que funcionam com as linguagens linguagens e protocolos já estudados nas seções anteriores deste capítulo: Protégé, que usa OKBC e OWL; SysmOntoX, que usa XML, OILED que usa OWL e Ontosaurus, que usa LOOM e PowerLoom.

\subsubsection{Protégé}

O Protégé ${ }^{13}$ possui um ambiente de edição de bases de conhecimento e uma arquitetura extensível para a criação de outras ferramentas, ou seja, ele também tem uma API. Esta API é dedicada a desenvolvedores de software que desejem implementar novas linguagens e características que eles gostariam de suportar em suas aplicações (RIBIÈRE; CHARLTON, 2001).

O Protégé conta com um ambiente gráfico e interativo, onde pode-se utilizar manipulação direta para administrar uma ontologia. Ele é utilizado em diversos domínios, como protocolos para tratamento de câncer e estações de energia nuclear. Controles em árvore permitem uma navegação simples e rápida através da hierarquia de classes. O Protégé usa formulários como sua interface para preenchimento dos valores das instâncias. O modelo de conhecimento do Protégé é compatível com o OKBC e OWL, com o uso do plugin OWL. Ele inclui suporte para classes e hierarquia de classes, com herança múltipla, instâncias, especificações de facetas pré-definidas ou arbitrárias para instâncias, que incluem valores permitidos, restrições de cardinalidade, propriedades funcionais inversas, meta-classes e hierarquia de meta-classes.

A arquitetura do Protégé é aberta e modular, provendo escalabilidade e extensibilidade, além da criação de plugins. Desta forma é possível a conversão da ontologia em outras linguagens, como o CLIPS por exemplo. A maioria dos plugins pode ser classificada em

\footnotetext{
${ }^{13}$ http://protege.stanford.edu/
} 
uma destas três categorias: backends de importação e exportação das ontologias em vários formatos diferentes, como RDF, XML e OWL por exemplo; slot widgets que são usados para mostrar e editar valores das propriedades, alguns incluem interfaces com imagens, vídeo e áudio e manipulação de diagramas; e os plugins que são aplicações baseadas em conhecimento estritamente conectadas com as bases de conhecimento Protégé, ficando geralmente em abas.

Estes últimos são o tipo mais popular e incluem plugins de visualização, combinação e administração de versões. O OntoViz ${ }^{14}$ e o Jambalaya (STOREY et al., 2001) ${ }^{15}$, são exemplos de visualizadores gráficos da base de conhecimento. O Jambalaya permite navegação interativa, mostrando um grafo para demonstrar as conexões entre os agrupamentos de informação. O plugin PROMPT(NOY; KLEIN; KUNNATUR, 2004) ${ }^{16}$ provê um ambiente para a administração de múltiplas ontologias. Seus componentes incluem ferramentas para combinação de ontologias, que auxiliam o usuário a encontrar similaridades entre as fontes das ontologias para combiná-las, ferramentas para controle de versões e ferramentas para extração semântica de partes de uma ontologia (GÓMEZ-PÉREZ, 2002).

\subsubsection{SymOntoX}

O SymOntoX ${ }^{17}$ (Symbolic Ontology Manager XML) é um protótipo de software para a gerência de domínios de ontologias. Há também uma API Java para interoperabilidade e integração com outros sistemas. Conceitos do domínio e relações são modelados de acordo com OPAL (Object, Process and Actor modelling Language) uma metodologia para representação de ontologias. Um validador de consistência verifica se a ontologia está de acordo com os axiomas propostos no OPAL. De acordo com OPAL, conceitos são organizados por significado dessas três idéias de modelagem primárias: Ator, qualquer entidade relevante do domínio que está apta para ativar ou executar um processo, como um vírus ou um hormônio; Processo, uma atividade com a intenção de satisfazer um objetivo (goal), como glicólise; e Objeto, uma entidade passiva no qual o processo opera, como uma enzima.

SymOntoX foi concebido para ser um serviço disponível na Internet que suporta um formulário gráfico para interface com o usuário, na edição e visualização da ontologia. Existe

\footnotetext{
${ }^{14} \mathrm{http}: / /$ protege.stanford.edu/plugins/ontoviz/ontoviz.html

${ }^{15} \mathrm{http}: / /$ protege.stanford.edu/plugins/jambalaya/jambalaya-simple.htm

${ }^{16} \mathrm{http}: / /$ protege.stanford.edu/plugins/prompt/PROMPT_2-1_Documentation.zip

${ }^{17} \mathrm{http}: / / 194.183 .24 .3 /$ symontos/symontosNS.html
} 
também uma funcionalidade de diagramação para navegação no conteúdo da ontologia (GÓMEZ-PÉREZ, 2002). É baseado em XML, todas as informações são guardadas em um banco de dados XML, e usa Java, para garantir a independência da plataforma. O sistema tem três distinções quanto aos usuários, que podem ser registrados como "user", com direito apenas de leitura; "superuser" com direito de leitura e de propor novos conceitos e "ontology master", que é o responsável pela aceitação ou não dos novos conceitos propostos. O sistema pode ainda ser usado de diferentes formas: como um glossário, onde apenas o nome e a descrição em linguagem natural dos conceitos é mostrado; ou como uma enciclopédia, onde também são mostradas as relações de hierarquia e a similaridade entre os conceitos; como um sistema de ontologias, onde todos os relacionamentos são mostrados e como uma base de conhecimento, onde incluem-se todas as instâncias dos conceitos.

\subsubsection{OILED}

OILED ${ }^{18}$ é um editor de ontologias gráfico que permite ao usuário construir ontologias usando a linguagem DAML+OIL e OWL. OILED oferece um ambiente de quadros para modelagem, enquanto ainda suporta uma rica expressividade quando requerido. Isto foi uma das causas para o sucesso já que esta abordagem é vital para o exercício de modelagem, especialmente para biólogos (BECHHOFER; GOBLE; HORROCKS, 2001). Ferramentas como o Protégé e OntoEdit também usam o paradigma baseado em quadros. Classes são definidas em termos de suas superclasses e restrições de propriedades. O modelo de conhecimento expressivo permite o uso de composições de descrição complexas como regras de filtragem. Isto está em contraste com muitos editores baseados em quadros, onde estes quadros anônimos devem ser nomeados antes que sejam usados como modelos.

Um aspecto chave do comportamento do OILED é o uso do mecanismo de raciocínio FaCT para classificar ontologias e verificar consistência através de uma tradução de DAML+OIL

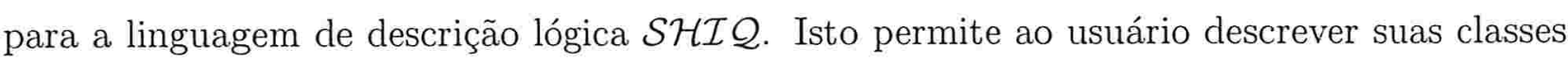
de ontologias e ver o mecanismo de raciocínio determinar o lugar apropriado na hierarquia para a definição. Algumas vezes uma definição de conceito equivocada pode ser determinada como insatisfazível.

O esquema RDF do DAML+OIL ou OWL podem ser usados para carregar e guardar

\footnotetext{
${ }^{18}$ http://oiled.man.ac.uk/index.shtml
} 
ontologias. Em adição, a ferramenta lê e escreve hierarquia de conceitos em RDF puro e

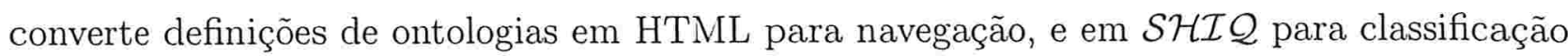
posterior pelo FaCT através de sua interface CORBA. A hierarquia de conceitos pode também ser convertida em um formato legível pela ferramenta Dotty da AT\&T (GÓMEZ-PÉREZ, 2002).

\subsubsection{Ontosaurus}

Ontosaurus $^{19}$ foi desenvolvido pelo Information Sciences Institute (ISI) na USC (University of South California). Ele consiste de dois módulos: um servidor de ontologias, que usa LOOM ou PowerLoom como sistema de representação de conhecimento e um servidor de navegação de ontologias que dinamicamente cria páginas HTML, incluindo imagens e documentação textual, que demonstram a hierarquia da ontologia. A ontologia pode ser editada e consultada em formulários HTML, e pode ser convertida de LOOM / PowerLoom para Ontolingua, KIF e $\mathrm{C}++$.

A tela do navegador é dividida em cinco quadros: barra de ferramentas, janela de referência, marcações, controle de marcações e janela de conteúdo. Na barra de ferramentas, pode-se selecionar um entre os oito exemplos pré-escritos na página, onde é possível consultar os módulos para cada ontologia. Há os botões "show", para carregar o módulo, "view" para ver as descrições do módulo, "hold window" para mover a janela de conteúdo para a janela de referência, "options" para configurar diversas opções do Ontosaurus. Há ainda uma caixa de busca, com opções boleanas. Na janela de referência, pode-se consultar as informações sobre os conceitos da ontologia atual e compara-los com os conceitos da janela de conteúdo. A parte de marcações exibe os itens previamente marcados pelo quadro de controle de marcações, onde é possível manuseá-los.

\footnotetext{
${ }^{19} \mathrm{http}: / /$ www.isi.edu/isd/ontosaurus.html
} 


\section{Construindo Uma Bio-Ontologia}

Neste capítula são apresentados alguns conceitos que norteiam a construção das ontologias, seguido pelas suas descrições, tanto em PowerLoom como OWL. Ao final são apresentadas as dificuldades encontradas e como elas foram contornadas. No apêndice é possível obter o código-fonte de ambas as ontologias.

\subsection{Como construir uma Ontologia}

Há várias maneiras de se construir uma ontologia. A maioria dos processos envolve meios interativos, onde se inicia com um simples protótipo, que evolui com o tempo. Pode-se resumir este processo por etapas. As regras gerais aqui descritas tem por base (SCHULZE-KREMER, 2002).

Dados os componentes descritos a seguir, conjunto de conceitos, proposições sobre os conceitos, axiomas, formalismos de representação do conhecimento, a relação de subconjunto e a relação de membro de um determinado conjunto, aplica-se os seguintes passos, para cada conceito:

- Procura-se e anota-se uma única definição explícita para cada conceito. Esta definição deve ser precisa o suficiente para discriminar este conceito de todos os outros conceitos da ontologia e deve ser detalhada o suficiente para prover um claro entendimento de seu significado. Nesta parte deve-se se estabelecer todos os sinônimos dos termos.

- Quando da adição de uma subclasse a uma classe de conceitos deve-se usar um, e apenas um, critério consistente e explícito para a separação em cada uma das subclasses. Quando este princípio de projeto é seguido, a ontologia conta com uma árvore hierárquica de subclasses que pode ser usada como uma árvore de decisão quando da 
adição de novos conceitos. Isto irá requerer a escolha do modelo de herança, se múltipla ou simples.

- A disjunção ou não de uma subclasse deve estar explícita, ou seja, se um conceito deve estar somente em uma classe, ou ele pode estar em mais de uma classe simultaneamente. Isto irá ajudar enormemente mais tarde em procuras através da hierarquia de subclasses, focando as buscas.

- Obter uma conectividade de cada termo da ontologia, via as relações "é uma subclasse de" ou "é um membro de" (ou o inverso), com os demais. Isto é, deve existir ao menos uma relação "é uma subclasse de" ou "é um membro de" (ou o inverso) para cada um dos conceitos da ontologia. Desta forma a organização dos conceitos na ontologia se torna mais simples, pois todos os conceitos serão definidos consistentemente a todas as partes da ontologia. Caso se deseje no futuro fazer uma integração desta ontologia com outra, o surgimento de conflitos por não disjunção de conceituações será minimizado, já que se existe a representação de uma disjunção de um conceito, ela já estará relacionada com este, através das relações "é uma subclasse de" ou "é um membro de" (ou o inverso).

- Deve-se usar apenas um nó raiz. Este conceito deve ser escolhido de forma a ser geral o suficiente para abraçar uma variedade de conceitos relevantes ao domínio. Se não, diferentes tipos de conflitos podem emergir.

- Adicionar conhecimento de base (definições) para cada conceito para expressar propriedades relevantes ao domínio. Os atributos e relacionamentos devem ser eles próprios reificados primeiro na ontologia, para uma capacidade máxima de inferência. Anota-se conceitos com atributos mencionados anteriormente.

- Adiciona-se ligações dos conceitos na ontologia para dicionários de linguagem natural, bancos de dados de palavras chave etc. Caso necessário, faz-se a interface com uma aplicação.

\subsubsection{Regras para Nomear Conceitos}

As seguintes regras fazem uma ontologia mais legível, segundo (SCHULZE-KREMER, 2002).

- Usar a forma singular em um nome de conceito; 
- Usar letras minúsculas para classes;

- Instâncias e nomes devem começar com letras maiúsculas;

- Acrônimos devem ter todas as letras maiúsculas;

- Deve-se observar os requisitos de sintaxe do formalismo de representação;

- Aspas, hífens etc, devem ser requeridos ou proibidos;

- Nomes únicos devem ser requeridos pelo formalismo de representação;

- Se o conceito pode ser definido em uma palavra, ela deve ser usada. Se não, concatene duas ou mais palavras. Em todo caso não se deve passar de 4 palavras para nomear um conceito;

- Uma subclasse deve ser criada para um novo conceito que não se enquadre nos demais, e não aparecer de antemão.

- Fazer os conceitos fáceis de serem reconhecidos;

- Adicionar o critério de subclassificação imediatamente quando óbvio;

- Sempre informar sinônimos onde possível.

Os benefícios desta metodologia são significantes. Quando da adição de um novo conceito, pode-se usar o critério de discriminação da ontologia como uma árvore de decisão para se caminhar da raiz até cada ramificação para se decidir deterministicamente onde o conceito deve estar. Pode-se descobrir se o conceito já está presente, possivelmente sob outro nome, então o processo de inserção é apenas adicionar um sinônimo ao conceito existente. Ou encontra-se um ponto da hierarquia onde nenhuma alternativa parece ser apropriada. Este é o lugar onde o novo conceito deve ser adicionado, de forma direta, ou usando alguns outros conceitos para separar os conceitos existentes da nova ramificação. Isto também garante a consistência da ontologia existente, e a manutenção da hierarquia de generalização e especialização depois da inserção de um novo conceito. A procura por um conceito conhecido ou não, se realiza da mesma forma, ou seja, percorrendo-se a árvore de decisão do critério de discriminação. 


\subsubsection{Integração entre Ontologias}

A possibilidade da construção de uma grande e completa ontologia para biologia molecular versus inúmeras ontologias pequenas orientadas a tarefas específicas tem sido exaustivamente debatida na comunidade de Inteligência Artificial (SCHULZE-KREMER, 2002). De um lado uma ontologia compreendendo todo o domínio, certamente seria muito útil se pudesse ser desenvolvida e mantida. De outro lado, parece ser muito mais eficiente e efetivo possuir diversas pequenas ontologias de subdomínios, que levam menos tempo para serem exploradas e requerem menos perícia em seu crescimento e manutenção, estando então em posição de serem usadas primeiro.

Em princípio, a abordagem de pequenas ontologias de subdomínios é a mais prática, exceto quando o objetivo é combinar todas as ontologias de subdomínios. Nesse caso, muito trabalho deve ser refeito já que a integração de ontologias dificilmente pode ser um processo automatizado. Cada conceito deve ser localizado e identificado nas várias ontologias de subdomínios, o que envolve procura manual além da leitura e comparação das definições dos conceitos. Uma decisão deve ser tomada se o conceito é similar o suficiente para ser combinado em um ou se vários conceitos similares devem ser preservados. Então, estes conceitos devem ser adicionados a nova ontologia que irá incorporar todos os conceitos das ontologias de subdomínios.

No caso especial onde a raiz ou algum nível do topo dos conceitos de uma ontologia casa exatamente com conceitos em outra ontologia, esses ramos podem ser combinados. Entretanto, neste caso o formato dos dados (sintaxe, formalismo de representação) e as relações entre conceitos das duas ontologias ainda devem ser verificados.

Já que este processo de integração de ontologias é bastante trabalhoso, e pode levar ao aparecimento de inconsistências, faz mais sentido começar com uma ontologia mais geral, de um nível superior, e poder acomodar todos os diversos tipos de ontologias esperadas no domínio da aplicação.

Norteadas pelos princípios expostos acima, foram construídas duas ontologias semelhantes, uma em PowerLoom e outra em OWL, descritas a seguir. 


\subsection{Ontologia Proposta}

Nesta parte do trabalho é proposta uma pequena bio-ontologia, onde pode-se observar os principais conceitos do PowerLoom e seus mecanismos de inferência, além de ilustrar os benefícios de seu uso. A ontologia foi escrita tendo em mente uma referência cruzada com o Gene Ontology. Como apoio, foi também consultado o trabalho do Ontology Group do ISTC-CNR ${ }^{1}$.

Como ponto de partida, tudo será derivado de "coisa". Desde elementos até reações, e qualquer coisa poderá ter seu número GO:

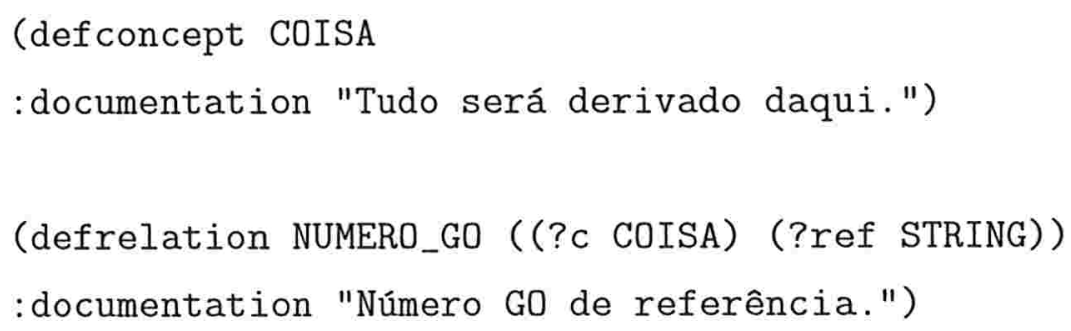

Agora pode-se definir algumas substâncias básicas da bioquímica e seus sinônimos, começando pela própria definição de substância:

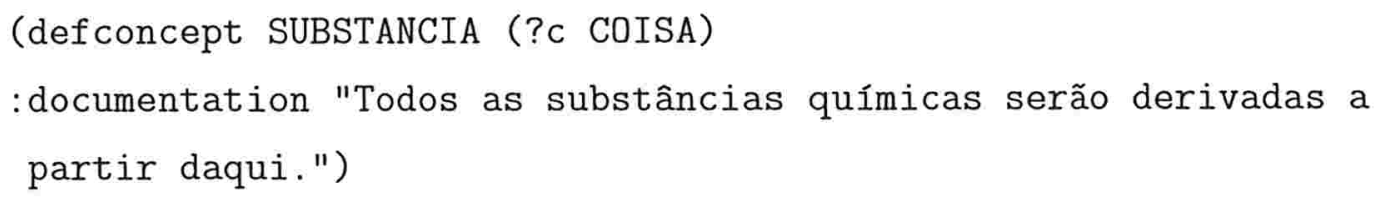

O código acima define o conceito de substância, que é uma subclasse de 'coisa'.

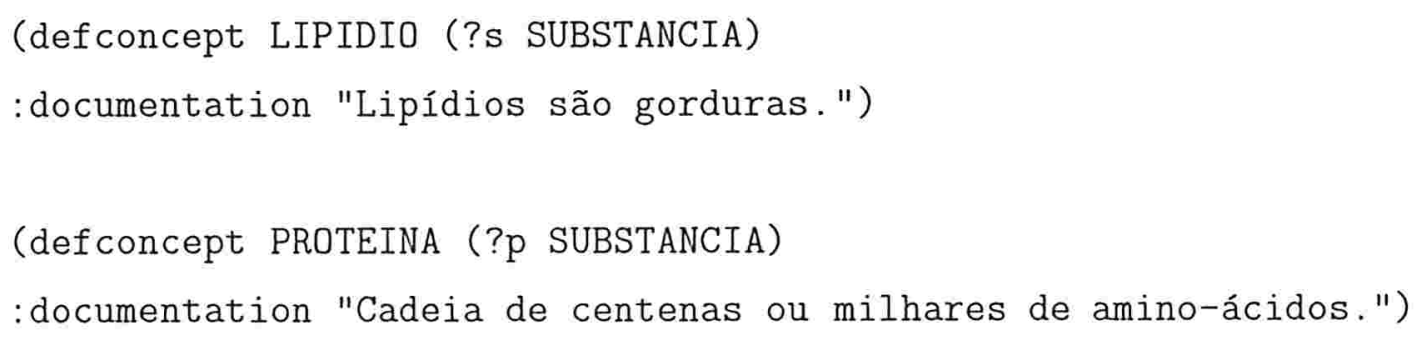

\footnotetext{
${ }^{1}$ O Ontology Group agora faz parte do Laboratório de Ontologia Aplicada em: http://www.loa-cnr.it/
} 
(defconcept CARBOIDRATO (?s SUBSTANCIA)

:documentation "Açúcar.")

Entretanto, glicídio e carboidrato são sinônimos:

(defconcept GLICIDIO (?c)

$: \Leftrightarrow$ (CARBOIDRATO ?c)

: documentation "Glicídio e Carboidrato são sinônimos.")

Agora pode-se testar os sinônimos:

(assert (CARBOIDRATO GLICOSE))

(assert (GLICIDIO SACAROSE))

(assert (CARBOIDRATO RAFINOSE))

(assert (GLICIDIO ESTAQUIOSE))

(assert (GLICIDIO AMIDO))

(ask (CARBOIDRATO GLICOSE))

TRUE

(ask (GLICIDIO GLICOSE))

TRUE

(ask (GLICIDIO SACAROSE))

TRUE

(ask (CARBOIDRATO SACAROSE))

TRUE 
Os carboidratos são conhecidos por serem compostos a partir de um ou mais sacarídeos, que podem ser obtidos como resultado de uma hidrólise. A quantidade de sacarídeos de um carboidrato pode ser definida pela seguinte função, que recebe um número inteiro:

(deffunction QUANTIDADE_SACARIDEOS ((?c CARBOIDRATO)) :-> (?n INTEGER))

Agora pode-se fazer afirmações com o comando assert sobre alguns carboidratos e seu respectivo número de sacarídeos:

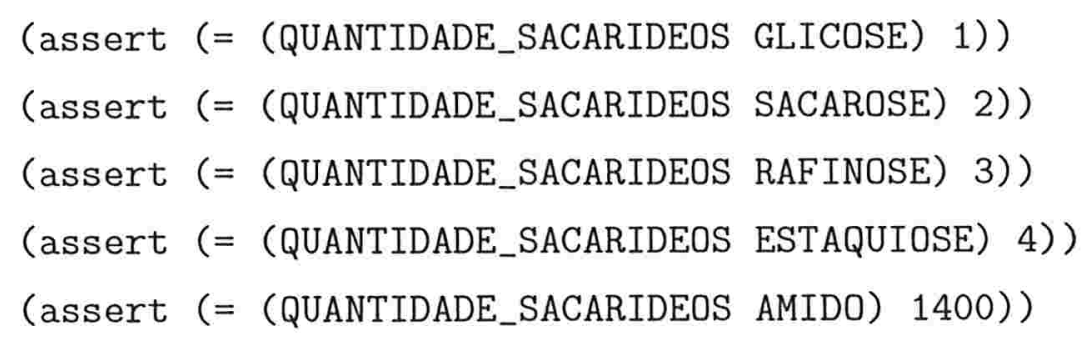

Os carboidratos podem ser classificados como monossacarídeos, dissacarídeos, trissacarídeos, oligossacarídeos e polissacarídeos. Se um carboidrato for um monossacarídeo ele não pode ser um dissacarídeo ou um trissacarídeo ou qualquer outro tipo de carboidrato. Com o comando (assert (closed MONOSSACARIDEO?)) afirma-se explicitamente que quem não for informado como monossacarideo não é um monossacarideo. Isto é, habilita-se a hipótese de mundo fechado ${ }^{2}$ para o conceito MONOSSACARIDEO O mesmo ocorre para os outros tipos de carboidrato, exceto o oligossacarídeo, que pode ser um dissacarídeo ou um trissacarídeo por exemplo.

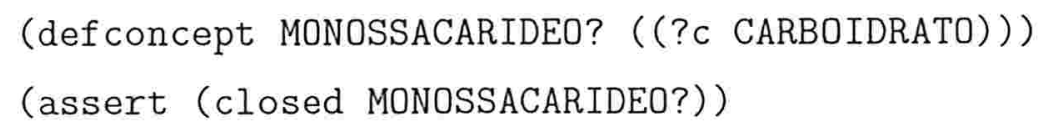

\footnotetext{
${ }^{2} \mathrm{~A}$ hipótese do mundo fechado é feita quando se presume que a base de conhecimento possui toda a informação positiva pertinente, de modo que apenas é verdadeiro aquilo que está explicitamente declarado, ou é explicitamente daí derivável; caso contrário presume-se que seja falso.
} 


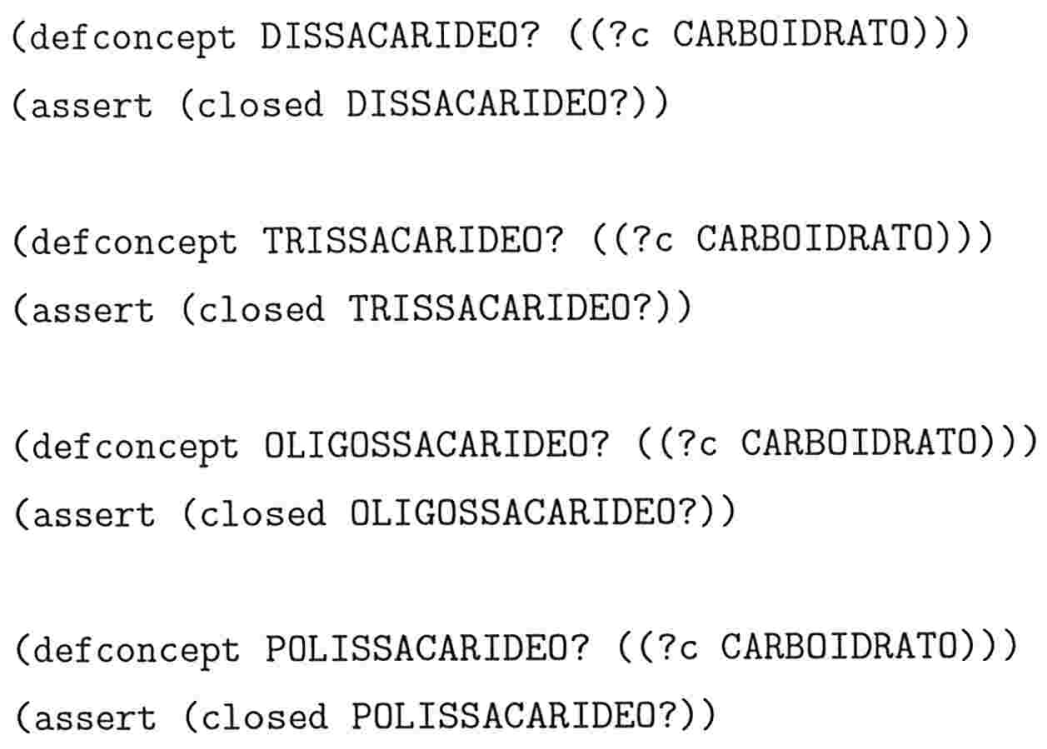

Note que as definições anteriores contém um ponto de interrogação após o nome de cada uma. Isso significa que essas relações não estão definidas, ou seja, não estão informadas as condições para que se infira o que é ou não um monossacarídeo por exemplo. Pode-se agora catalogar os carboidratos em suas categorias:

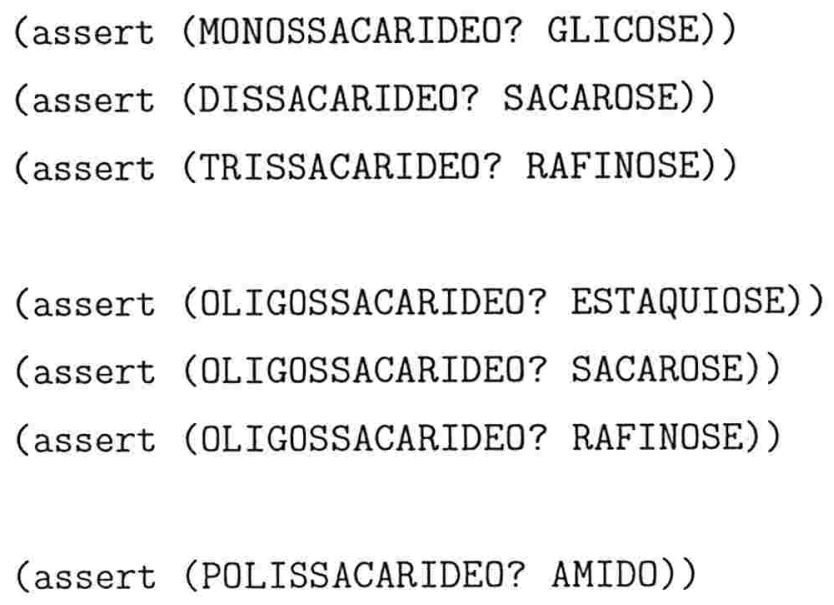


(ask (MONOSSACARIDEO? GLICOSE))

TRUE

(ask (not (DISSACARIDEO? GLICOSE)))

TRUE

(ask (not (MONOSSACARIDEO? SACAROSE)))

TRUE

A ontologia completa em OWL pode ser sintetizada na figura 1, obtida através do plugin $\mathrm{EzOWL}^{3}$.

Já na figura 2 pode-se ver a própria repetição da estrutura do Carboidrato dentro do conceito Glicídio, já que são sinônimos. Essa figura foi obtida através do plugin Jambalaya (STOREY et al., 2001) do Protégé.

Os códigos da ontologia completa, em PowerLoom e OWL são apresentados no Apêndice.

Depois de populada a ontologia com instâncias de carboidratos, pode-se inferir as características que um carboidrato deve ter para ser um tipo determinado de sacarídeo. O que será feito é inferir as regras que especificam e diferenciam os tipos de carboidrato:

(induce-inference-rules MONOSSACARIDEO? CARBOIDRATO)

Depois de algum processamento, PowerLoom obtém a seguinte regra:

$(\Leftrightarrow($ AND $(/$ STELLA/=< (QUANTIDADE_SACARIDEOS ?Y) $\mid$ L $\mid 1))$ (MONOSSACARIDEO? ?Y))

Essa regra diz que um monossacarídeo deve ter o atributo QUANTIDADE_SACARIDEOS menor ou igual a 1. De forma semelhante, pode-se obter as regras para os outros tipos de carboidratos:

\footnotetext{
${ }^{3}$ http://iweb.etri.re.kr/ezowl/
} 


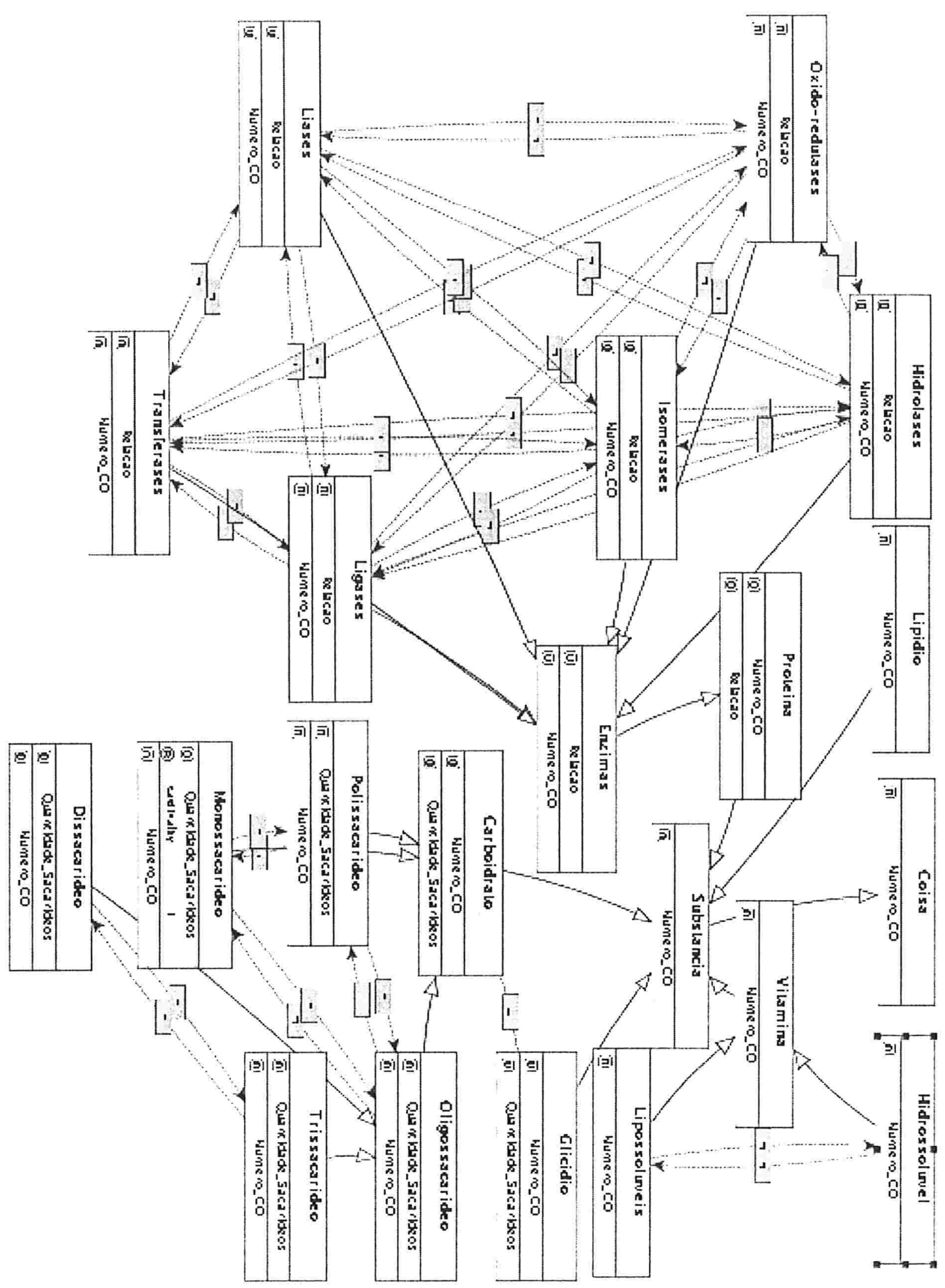

Figura 1: Ontologia proposta. 


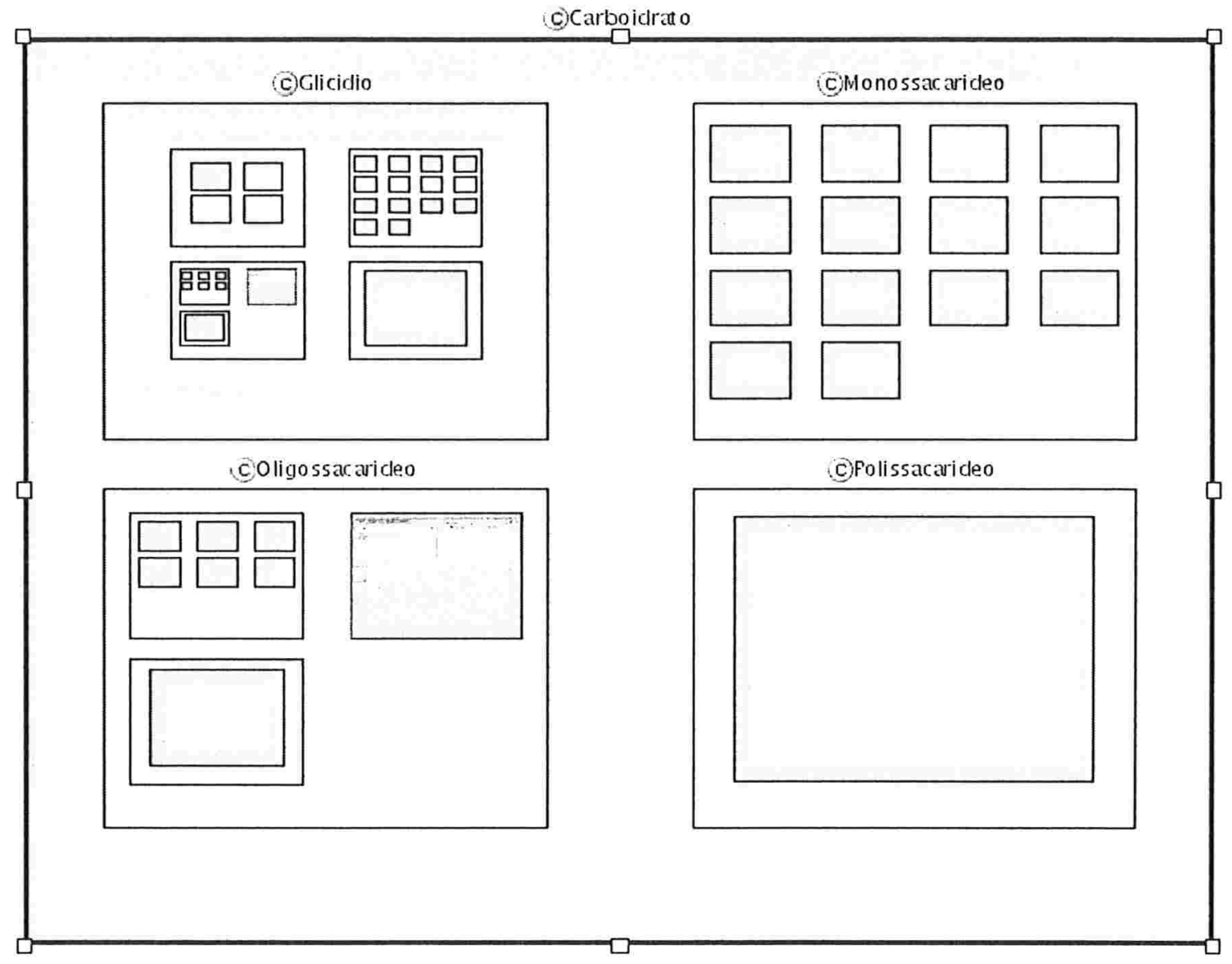

Figura 2: Zoom no conceito Carboidrato, onde pode-se ver a repetição dos mesmos subconceitos e instâncias tanto em Carboidrato quanto Glicidio. 
(induce-inference-rules DISSACARIDEO? CARBOIDRATO)

Onde se obterá:

$(\Leftrightarrow$ (AND (QUANTIDADE_SACARIDEOS ?Y |L|2)) (DISSACARIDEO? ?Y))

Já essa regra diz que a quantidade de sacarídeos de um dissacarídeo é exatamente igual a 2. E assim sucessivamente:

(induce-inference-rules TRISSACARIDEO? CARBOIDRATO)

$(\Leftrightarrow$ (AND (QUANTIDADE_SACARIDEOS ?Y |L|3)) (TRISSACARIDEO? ?Y))

(induce-inference-rules OLIGOSSACARIDEO? CARBOIDRATO)

$\Leftrightarrow$ (AND (/STELLA/>= (QUANTIDADE_SACARIDEOS ?Y) $\mid L / 2)$

(/STELLA/=< (QUANTIDADE_SACARIDEOS ?Y) $\mid$ L $\mid 10)$ ) (OLIGOSSACARIDEO? ?Y))

A primeira regra diz que um trissacarídeo tem a quantidade de sacarídeos igual a 3, enquanto que a segunda diz que um oligossacarídeo tem mais de 2 e menos de 10 sacarídeos.

É possível agora incorporar as regras descobertas no banco de conhecimento:

(assert-induced-rules)
Asserting INDUCED-RULE-0
Asserting INDUCED-RULE-1
Asserting INDUCED-RULE-2
Asserting INDUCED-RULE-3
Asserting INDUCED-RULE-4

E então, pode-se saber se um novo carboidrato é um oligossacarídeo: 
(assert (CARBOIDRATO FRUTANO))

(assert (= (QUANTIDADE_SACARIDEOS FRUTANO) 3))

(ask (OLIGOSSACARIDEO FRUTANO))

TRUE

(ask (TRISSACARIDEO FRUTANO))

TRUE

Estas regras inferidas automaticamente também poderiam ser explicitamente implementadas:

(defconcept MONOSSACARIDEO ( (?c CARBOIDRATO))

$: \Leftrightarrow$ (and (CARBOIDRATO ?c)

$(=($ QUANTIDADE_SACARIDEOS ?c) 1))

(def concept DISSACARIDEO ( (?c CARBOIDRATO))

$: \Leftrightarrow>$ (and (CARBOIDRATO ?c)

$(=($ QUANTIDADE_SACARIDEOS ?c) 2))

(def concept TRISSACARIDEO ((?c CARBOIDRATO))

$: \Leftrightarrow>$ (and (CARBOIDRATO ?c)

$(=($ QUANTIDADE_SACARIDEOS ?c) 3)) $)$

(def concept OLIGOSSACARIDEO ((?c CARBOIDRATO))

$: \Leftrightarrow>$ (and (CARBOIDRATO ?c)

(> (QUANTIDADE_SACARIDEOS ?c) 1)

(<=(QUANTIDADE_SACARIDEOS ?c) 10)) )

Implementadas explicitamente, elas funcionam de forma igual as regras descobertas pelo mecanismo de inferência. 


\subsection{Uma Ontologia Semelhante Usando OWL}

Para fins de estudo e comparação, uma ontologia semelhante, foi escrita em OWL, usando Protégé 3.0 (build 131) com o plugin OWL 1.3, que é o plugin padrão para a escrita em OWL no Protégé, já que OWL não é o formato original do Protégé. Também foi usado o plugin ezOWL que permite a construção da ontologia de forma gráfica, sob Java (Blackdown-1.4.201). O código-fonte da ontologia em OWL está disponível no Apêndice. É a mesma ontologia que pode ser visualizada nas figuras 1 e 2 .

\subsection{Dificuldades Encontradas}

Há muitas dificuldades para serem ultrapassadas quando da construção de uma ontologia. Algumas delas são inerentes ao processo de construção de ontologias, outras surgem da área de aplicação do trabalho.

Mesmo os especialistas na área tendo um bom entendimento dos termos técnicos, encontrar uma definição apropriada pode se tornar muito difícil devido aos significados sobrepostos escondidos em uma palavra, por exemplo gene.

Já que não há uma regra definitiva para determinar o melhor (ou o mais informativo) critério de subclassificação de uma dada classe é deixado como uma decisão arbitrária como classificar subclasses desta classe. Isto implica que não haverá uma melhor ontologia, ou uma "ontologia ótima" para um dado conjunto de conceitos, mas apenas ontologias diferentes, que se aplicam de forma melhor ou pior ao problema proposto. Também, já que o conteúdo das informações dos conceitos ainda precisa ser adicionado em uma ontologia e não é precisamente conhecido antecipadamente, a escolha do critério de subclassificação, que é uma das tarefas na construção de uma ontologia, pode levar a sub-estruturas e heranças mais complexas que o necessário. 
Pode-se exemplificar essas distinções ontológicas através do seguinte exemplo: DNA pode significar várias entidades diferentes. Primeiro, substância física. Segundo, uma classe particular de substâncias químicas, que incluem características gerais comuns a todas as moléculas de DNA e é usada por exemplo em modelagem molecular. Terceiro, DNA pode significar um certo tipo de seqüência ou string que é um conceito matemático abstrato. Quarto, DNA é também usado no laboratório para referir-se a uma instância particular de uma seqüência, por exemplo, a seqüência do DNA da $E$. coli $K$ 12, que pode ser armazenada num banco de dados e precisa de um meio para existir. Existem ainda outras conotações de DNA citadas em (SCHULZE-KREMER, 2002).

Dois grandes problemas são a dificuldade em analisar a informação quando armazenada em arquivos texto e as inconsistências e incoerências advindas da ausência de um vocabulário unificado, que levam a mesma informação a ser representada em mais de uma forma. $O$ primeiro problema, que só existe no PowerLoom, já que OWL não foi feita para ser legível diretamente, pode ser resolvido através do navegador Ontosaurus, ${ }^{4}$ que pode ser visto na figura 3 .

Segundo (SCHULZE-KREMER, 2002), outras dificuldades, oriundas do processo de construção de ontologias, são:

- Perda de elementos da ontologia;

- Perda de classes;

- Perda de atributos e relações;

- Problemas com o grau das relações, 1 para 1 versus 1 para muitos e 1 para muitos versus muitos para muitos;

- Detalhamento excessivo de elementos supérfluos da ontologia, como guardar dados importantes em campos de texto livre ao invés de predicados reificados.

Fora do domínio específico da ontologia, temos outros problemas, como termos técnicos mal definidos ou controversos, dificuldade na separação e análise de homônimos, imprecisão ou falta de documentação das categorias que são as mais comuns.

\footnotetext{
${ }^{4}$ http://www.isi.edu/isd/ontosaurus.html
} 


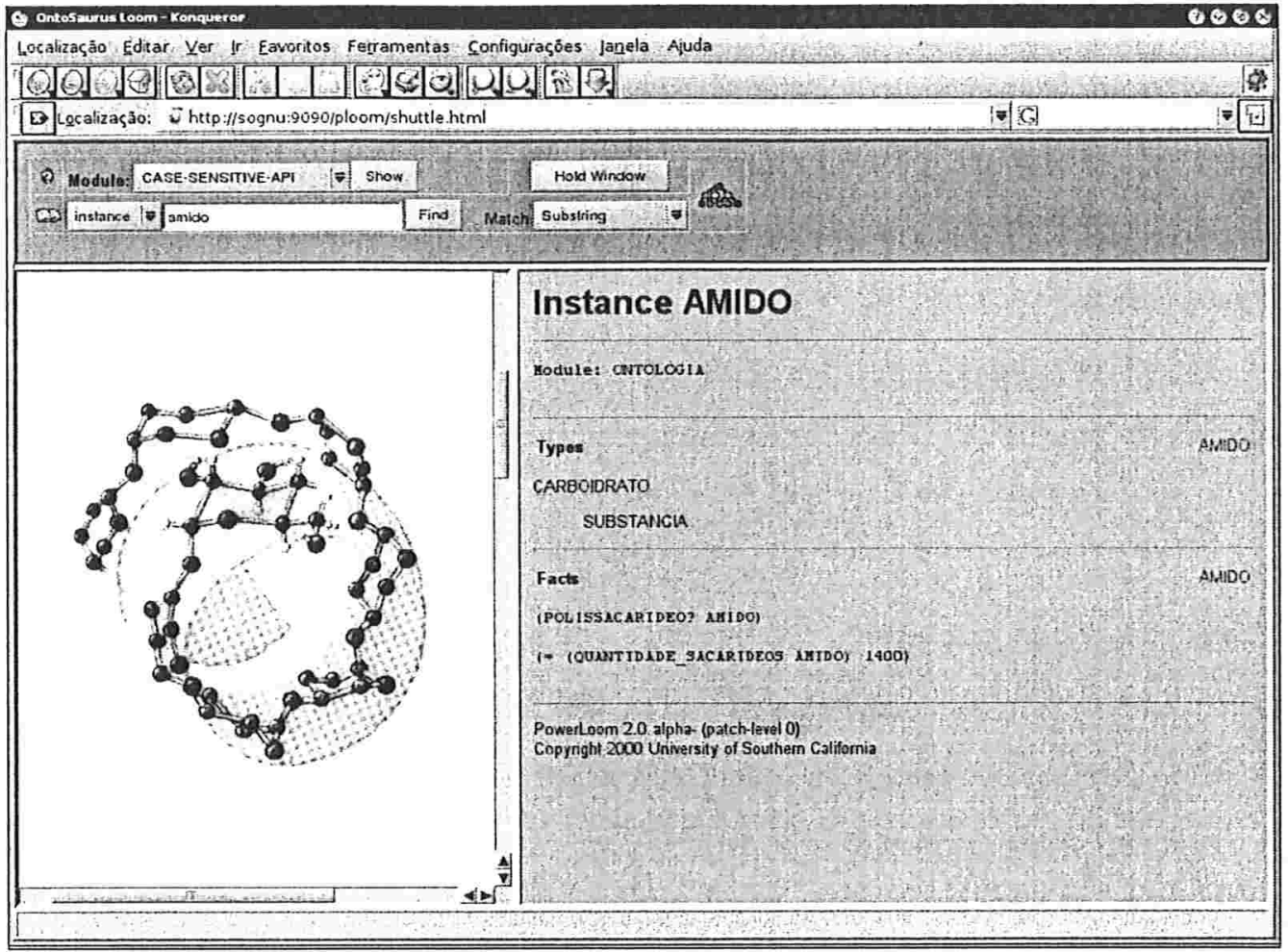

Figura 3: Visualização no Ontosaurus. Nessa figura pode ser visto o formulário de consultas.

De acordo com (SCHULZE-KREMER, 2002) isso leva a conclusão que os graus de liberdade quando da construção da ontologia, como o grau de abstração, a granularidade e os detalhes do domínio a ser modelado, determinam a qualidade prática da ontologia, de uma faixa partindo do inutilizável (muito abstrato, sem dar detalhar suficientemente a informação) ao impossível (granularidade e cobertura finais, com granularidade exagerada).

Antes do início da construção da ontologia, os maiores problemas são relacionados com os termos técnicos, muitas vezes mal definidos ou não precisamente documentados. Por exemplo, a diferença entre a quantidade de sacarídeos é o que difere um oligossacarídeo de um polissacarídeo. Entretanto, em grande parte das referências consultadas essas quantidades eram definidas em termos vagos, como 'poucos' e 'muitos'. Algumas vezes as classificações das substâncias relacionam aspectos diferentes, como tamanho e função por exemplo. Isso causa intesecções de definições, o que dificulta em muito sua compreensão.

Já durante a escrita da ontologia deste trabalho, foi possível notar que uma das maiores dificuldades é realmente a escolha da granularidade do conhecimento do domínio a ser modelado. Por exemplo, sabendo-se que uma proteína é uma cadeia de milhares de aminoácidos, 
escolher entre representar o colágeno simplesmente como uma proteína ou descrevendo toda a cadeia de aminoácidos que o formam. Outras dificuldades que surgiram durante a escrita da ontologia são os problemas com os graus das relações e sua reflexividade. Por exemplo, uma enzima pode catalizar várias reações e algumas reações precisam de mais de uma enzima para acontecerem.

Para o primeiro problema a solução escolhida foi fazer a ontologia com a menor granularidade possível, ou seja, só entrando nos detalhes de cada conceito se esses detalhes tivessem importância para outros conceitos ou relacionamentos da ontologia. O segundo ponto comentado é mais uma questão de modelagem. Diversas abordagens são possíveis para modelar os relacionamentos, elas apenas os tornam mais ou menos intrincados. Na ontologia os relacionamentos foram feitos de forma a se manterem o mais simples possível. 


\section{Comparação entre PowerLoom e $O W L$}

O propósito deste capítulo é analisar a relação entre a expressividade (o que pode ser dito) e a capacidade de inferência (o que pode ser obtido da informação representada) no PowerLoom e no OWL. Essas linguagens serão estudadas principalmente quanto ao grau de expressividade, facilidade de adição de novos conceitos e versatilidade de seus mecanismos de inferência. Os resultados foram obtidos levando-se em conta a experiência de codificar uma pequena ontologia, exposta no capítulo anterior. A ontologia completa está descrita no apêndice.

Existem diferentes necessidades em representação de conhecimento para diferentes aplicações, e algumas linguagens são mais apropriadas que outras para necessidades específicas de determinadas aplicações.

Quando do desenvolvimento de ontologias de domínio para uma aplicação, não é apenas necessário estudar as necessidades de representação de conhecimento e raciocínio para a aplicação, mas também a expressividade e os mecanismos de inferência providos pelas linguagens.

Diversos quesitos foram levados em conta para a realização da comparação entre OWL e PowerLoom. Esses quesitos foram escolhidos de acordo com sua relevância para essa comparação, a partir do framework CommonKADS ${ }^{1}$ em (CORCHO; GÓMEZ-PÉREZ, 2000).

Esse framework de avaliação diferencia a representação do conhecimento do mecanismo de inferência, de acordo com a tabela 1 .

\footnotetext{
${ }^{1}$ http://www.commonkads.uva.nl
} 


\begin{tabular}{|c|c|}
\hline Representação do Conhecimento & Mecanismo de Inferência \\
\hline Classes & Exceções \\
Metaclasses & Classificações automáticas \\
Atributos / Slots & \\
Taxonomias & Herança simples \\
Herança múltipla \\
Taxonomias & Raciocínio monotônico \\
& Raciocínio Não-monotônico \\
\hline Procedimentos & Execução de procedimentos \\
\hline Relacionamentos/Funções & Verificação de restrições \\
Instâncias / Indivíduos / Fatos & \\
Axiomas & Raciocínio com regras \\
\hline \multicolumn{2}{|c|}{ Encadeamento reverso } \\
Regras de Produção & Encadeamento direto \\
\hline
\end{tabular}

Tabela 1: Framework CommonKADS de avaliação.

\subsection{Por que OWL e PowerLoom?}

Enquanto OWL é uma recomendação do World Wide Web Consortium (W3C), PowerLoom apresenta diversas características adicionais ao OWL, principalmente em relação aos mecanismos de inferência. Por isso ambos foram mais profundamente estudados e escolhidos para a representação da ontologia proposta no capítulo anterior.

\subsubsection{Por que OWL?}

De acordo com (MCGUIMMESS; HARMELEN, 2004), a Web Semântica é uma visão para o futuro da Web na qual é dado o significado explícito da informação, tornando fácil para máquinas automaticamente processarem e integrarem informações disponíveis na Web. A Web Semântica será construída através da habilidade da linguagem XML de definir esquemas de rótulos (tags) customizados e na flexibilidade da representação de dados da linguagem RDF. O primeiro nível sobre RDF requerido para a Web Semântica é uma linguagem de ontologias que possa descrever formalmente o significado da terminologia usada em documentos Web. Se é esperado que máquinas possam fazer tarefas de inferência úteis nesses documentos, a linguagem deve estar abaixo da semântica básica de um esquema RDF. 
OWL foi projetado para satisfazer a necessidade de uma linguagem de ontologias para a Web. OWL é parte da pilha crescente de recomendações da W3C relacionadas à Web Semântica.

- XML provê uma sintaxe básica para documentos estruturados, mas não impõe restrições semânticas ao significado desses documentos.

- XML Schema é uma linguagem para restrição das estruturas de documentos XML que também extende o XML com tipos de dados.

- RDF é um modelo de dados para objetos (recursos) e relações entre eles, ele fornece uma semântica simples para este modelo de dados, e estes modelos de dados podem ser representados em uma sintaxe XML.

- RDF Schema é um vocabulário para descrever propriedades e classes de recursos RDF, com uma semântica para generalização-hierarquias de tais propriedades e classes.

- OWL adiciona mais vocabulário para a descrição de propriedades e classes: entre outras, relacionamentos entre classes (por exemplo: disjunção), cardinalidade (por exemplo: exatamente uma), igualdade, características de propriedades (por exemplo: simetria), e classes enumeradas.

\subsubsection{Por que PowerLoom?}

Apesar de prover algum suporte para definições do tipo quadros (frames), PowerLoom faz uso de uma linguagem de definição lógica de primeira ordem (apesar de conter algumas extensões) e não diretamente uma linguagem orientada a objetos ou uma linguagem de quadros. Por exemplo, em PowerLoom os conceitos não possuem realmente aberturas (slots). Ao invés disso, aplicamos relacionamentos e funções aos objetos. É possível incluir várias restrições, principalmente usando o que é chamado de predicados de quadros, o que impõe restrições no número ou tipo do preenchimento. No caso mais geral, pode-se codificar tanto axiomas quanto definições usando a linguagem de definição lógica.

Vamos imaginar que possuímos um determinado conceito chamado Pessoa. A este conceito, queremos anexar mais algumas informações, como Nome, Idade etc. A idéia geral é que muitas destas relações não são necessariamente estritamente ligadas a conceitos particulares. 
Por exemplo, Nome e Idade podem ser aplicados corretamente a conceitos como Vinho ou Filmes ou muitas outras coisas. Isto significa que ou tem-se que adicionar essas relações em um ponto alto da hierarquia, o que não é de muita ajuda para se conhecer a informação anexada, ou então obtêm-se uma ontologia que não é tão fácil de ser extendida quando se necessita relacionamentos adicionais. O princípio geral do PowerLoom é que deva ser fácil anexar a informação dos relacionamentos em qualquer lugar que isto faça sentido.

A idéia que relacionamentos ou funções como Nome ou Idade tenham uma significado independente é um pouco diferente das representações baseadas em quadros ou representação de objetos. Isto acontece porque PowerLoom é baseado na lógica e na lógica clássica não existem slots (aberturas). Existem predicados e funções. O PowerLoom ultrapassa em alguns lugares a lógica clássica estrita e introduz distinções adicionais (como conceitos), mas a idéia geral por trás do PowerLoom é que ele usa uma formulação lógica de ontologias.

Dessa forma, a questão de "qual relação é anexada com qual conceito" realmente se torna mais uma questão da semântica do relacionamento. Se faz sentido afirmar o relacionamento sobre alguma entidade, então pode-se fazer isto. Por exemplo, carros típicos não tem nomes (no sentido de nomes individuais, não o nome do modelo). Mas alguns carros especiais e alguns carros pessoais ganharam nomes. Um Hot rod como o 'Greased Lightning' no filme 'Grease' é um exemplo de um carro que possui um nome. Então obtêm-se muita flexibilidade numa representação que permite relacionamentos e funções existirem como entidades próprias. No caso da construção de uma bio-ontologia essa característica é de extrema importância, pois não se sabe de antemão todas as características de todos os conceitos que fazem parte da ontologia. Bio-ontologias geralmente são bastante dinâmicas e a acomodação de novas descobertas, características ou propriedades deve ser feita constantemente e de forma simples. O fato de PowerLoom suportar raciocínio raciocínio padrão² (default reasoning), ao contrário de OWL, também é um fator importante.

O raciocínio não-monotônico é inerente a diversos problemas interessantes do ponto de vista da Inteligência Artificial. As primeiras aplicações na história a representarem explicitamente a não-monotonicidade foram os métodos de representação de conhecimento, conhecidos como redes semânticas e quadros, onde hierarquias de conceitos são utilizadas como base para a "herança não monotônica" de atributos. Outra aplicação se refere à interpretação associada

\footnotetext{
${ }^{2}$ Raciocínio padrão é um método de representação de conhecimento e raciocínio que permite tratar adequadamente com informação incompleta. Raciocínio com defaults é um método de raciocínio não-monotônico.
} 
a perguntas negativas em relação a um banco de dados. Por exemplo, como afirmar que não existe um vôo direto entre São Paulo (SP) e Manaus (AM) a partir de um banco de dados sobre vôos existentes. A afirmativa da não existência tem fundamento diante da hipótese de mundo fechado ${ }^{3}$, isto é, a suposição que todos os vôos estão representados no banco de dados. Esta interpretação da negação encontra aplicação também em linguagens de programação em lógica, como Prolog.

Expressões quantificadas universalmente, em lógica de primeira ordem, são válidas para qualquer elemento do domínio, sem nenhuma exceção. No entanto, certas situações do mundo real, por exemplo situações envolvendo percepção, ambigüidade, senso comum, causalidade ou predição, são tão complexas que qualquer conhecimento sobre elas será inevitavelmente incompleto. Um formalismo para raciocinar eficientemente sobre este tipo de situações deve admitir expressões que sejam válidas em geral e ser capaz de reconhecer e assimilar exceções quando necessário. Ao utilizar regras que apresentam exceções, corre-se o risco de ser obrigado a retirar algumas conclusões anteriores face a novas informações, o que caracteriza a não monotonicidade. A lógica clássica é dita Monotônica porque o conjunto de teoremas de uma teoria é sempre um subconjunto dos teoremas de qualquer extensão desta teoria.

Isto não acontece nas Lógicas Não-Monotônicas, que são extensões da lógica de primeira ordem que admitem inferências realizadas na ausência de informações contrárias e que podem ser invalidadas por novas informações. Ou seja, raciocínio não-monotônico prevê que um fato, após estabelecido na base de conhecimento, pode ser alterado.

Como dito, PowerLoom possui vários predicados que permitem a construção de diversas sentenças nas linhas sugeridas. Esses são chamados de predicados de quadro (frame predicates). Eles foram introduzidos para permitir aos usuários construírem discrições similares a vários sistemas de representação baseados em quadros, como no Protégé. Os relacionamentos que começam com a palavra RANGE- são usados para especificar tipo e número de afirmações sobre o relacionamento. Pode-se produzir um modelo, por exemplo, como o seguinte:

(deffunction age)

Pode-se usar afirmações RANGE e DOMAIN nos relacionamentos e funções, mas isto não é

\footnotetext{
${ }^{3} \mathrm{~A}$ hipótese do mundo fechado afirma que se não é possível provar um conceito/relação ou a sua negação a partir de uma base de conhecimento, então adiciona-se a negação desse conceito ou relação a esta base de conhecimento.
} 
comumente esperado. No PowerLoom, isto não é uma restrições de tipo, mas sim procedimentos de inferência. Se quisermos afirmar o seguinte:

(assert (domain age person))

(assert (age bottle-of-wine-23 5))

então o PowerLoom irá concluir que a 'garrafa-de-vinho-23' é do tipo Pessoa:

(ask (person bottle-of-wine-23))

TRUE

Isto acontece porque o PowerLoom usa as informações sobre os domínios e intervalos para inferências. Já que Idade tem o domínio de Pessoa, tudo com uma Idade deve ser também uma Pessoa, e PowerLoom pode usar esta regra em seu raciocínio. Então deve-se ficar atento ao domínio de cada definição.

\subsection{Representação do Conhecimento do Domínio}

Inicialmente serão comparadas as características quanto a definições dos componentes principais do conhecimento do domínio. Tanto no PowerLoom quanto no OWL podemos fazer declarações de conceitos simples:

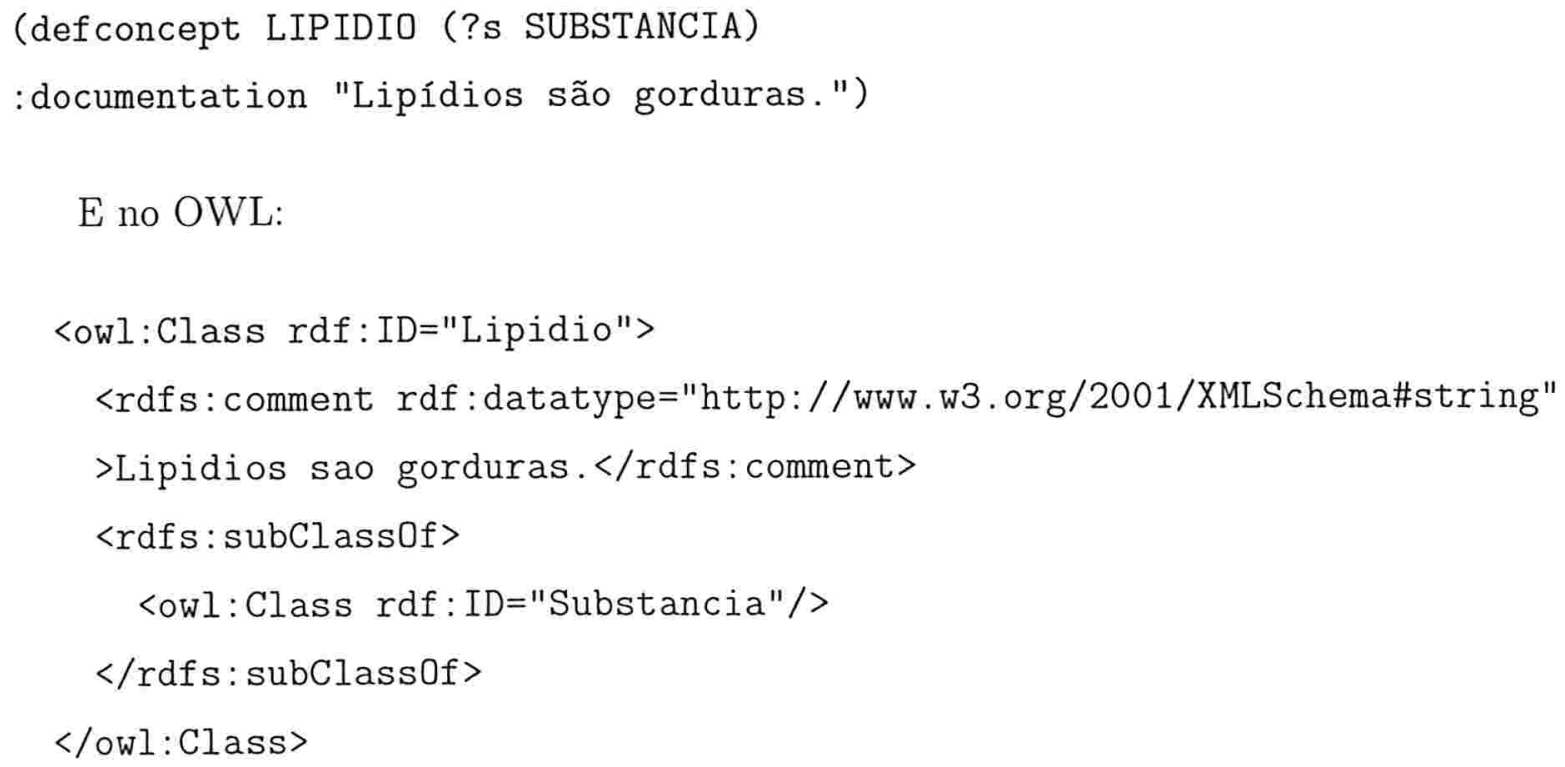


Relações representam um tipo de interação entre conceitos do domínio. Elas são formalmente definidas como qualquer subconjuto de um produto de $n$ conjuntos. Serão considerados os relacionamentos entre relações e outros componentes na ontologia. Funções são consideradas um tipo especial de relações, onde o valor do último argumento é único para uma lista de valores $\operatorname{dos} n-1$ argumentos procedentes. Em relação a valência dos relacionamentos, pode-se ter qualquer número de argumentos, tanto no PowerLoom como no OWL.

O PowerLoom possui também uma ampla lista de funções prontas, para os mais diversos usos. As próprias operações matemáticas e comparações, são funções do PowerLoom. Além dessas temos também diversas relações ${ }^{4}$ do tipo 'é um' e 'parte de'.

Exemplo de relação no PowerLoom e OWL:

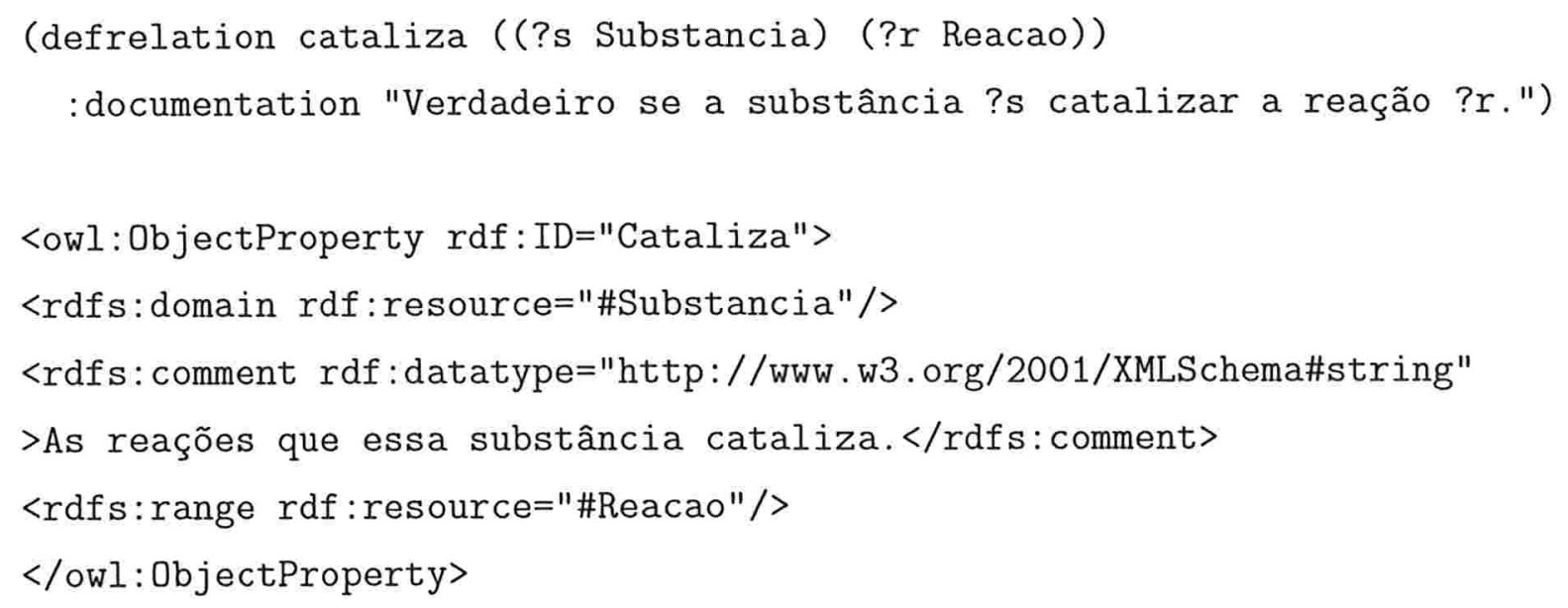

Tanto OWL como PowerLoom permitem definir instâncias de conceitos:

(assert (MONOSSACARIDEO XILUBIOSE))

(assert (= (QUANTIDADE_SACARIDEOS XILUBIOSE) 1))

e no OWL:

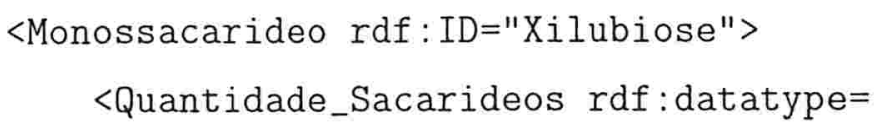

\footnotetext{
${ }^{4} \mathrm{~A}$ lista com todas os tipos de relacionamentos pré-especificados no PowerLoom pode ser obtida neste endereço: http://www.isi.edu/isd/LOOM/PowerLoom/documentation/manual/manual_10.html
} 


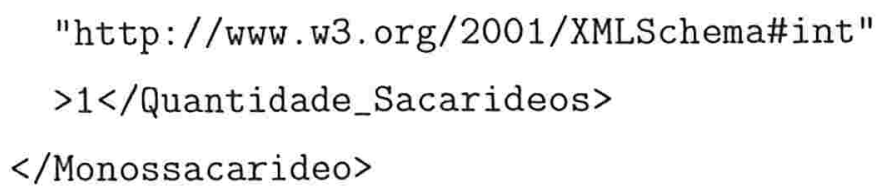

Axiomas modelam sentenças que são sempre verdadeiras. Eles são incluídos em uma ontologia para diversos propósitos, como definição do tipo de informação, verificação de tipos ou dedução de novas informações. Axiomas estão presentes em ambas as linguagens.

Regras de produção, que seguem a estrutura "Se-Então", são usadas para expressar conjuntos de ações e heurísticas que podem ser representadas independentemente da forma que serão usadas. Apesar de existirem no Loom, ainda não foram implementadas no PowerLoom. Há diversos grupos de pesquisas estudando regras de produção no OWL, sendo que já há algumas propostas (HORROCKS; PATEL-SCHNEIDER, 2003) de extensão da linguagem no sentido de acomodá-las.

Bossam $^{5}$ é uma ferramenta que permite implementar regras de produção sobre OWL e também fazer inferências (sobre fragmentos Lite e parcialmente sobre fragmentos DL). Entretanto o OWL deve ser convertido para a representação do Bossam, que usa N3 ${ }^{6}$.

Tanto PowerLoom quanto OWL possuem uma semântica formal. Por semântica formal compreende-se a especificação do significado ou comportamento da linguagem. A semântica formal do OWL está definida em (PATEL-SCHNEIDER; HAYES; HORROCKS, 2004) e (BECHHOFER et al., 2004), documentos que contém uma sintaxe abstrata de alto nível tanto para OWL/DL como OWL/Lite. Nesses documentos, um modelo teórico é apresentado para prover um significado formal para ontologias escritas em OWL. OWL é construído no topo de RDF que é uma linguagem de descrição de recursos, que por sua vez é escrita em XML. No PowerLoom tanto a semântica como a sintática da linguagem estão especificados em (CHALUPSKY; MACGREGOR; RUSS, 2003). O PowerLoom é baseado em uma variante do KIF ${ }^{7}$, mais precisamente do KIF 3.0, para expressar o conteúdo das definições e asserções.

$\mathrm{Na}$ Tabela 2 são comparados os principais componentes acerca do conhecimento do domínio.

Na Tabela 3 são comparadas as definições de conceitos.

\footnotetext{
${ }^{5}$ http://mknows.etri.re.kr/wiki/BossamRuleEngine/EnglishPage

${ }^{6}$ Notation 3 ou N3 é uma linguagem compacta e legível como alternativa ao RDF do XML: http://www.w3.org/DesignIssues/Notation3.html

${ }^{7}$ http://logic.stanford.edu/kif/
} 


\begin{tabular}{|c|c|c|}
\hline & PowerLoom & OWL \\
\hline Conceitos & + & + \\
\hline $\begin{array}{c}\text { Multi valência de } \\
\text { relacionamentos }\end{array}$ & + & + \\
\hline Funções & + & + \\
\hline Procedimentos & + & + \\
\hline Instâncias & + & + \\
\hline Axiomas & + & + \\
\hline $\begin{array}{c}\text { Regras de } \\
\text { produção }\end{array}$ & - & + \\
\hline Semântica formal & + & + \\
\hline
\end{tabular}

Tabela 2: Definições dos componentes principais do conhecimento do domínio.

\begin{tabular}{|c|c|c|}
\hline & PowerLoom & OWL \\
\hline Conceitos & & \\
\hline Metaclasses & + & + \\
\hline Partições & + & + \\
\hline Atributos & & \\
\hline Atributos de instância & + & + \\
\hline Atributo próprio de classe & + & + \\
\hline Polimorfismo & + & + \\
\hline Escopo local & + & + \\
\hline Atributos & & \\
\hline Valor padrão (defaults) & + & - \\
\hline Restrições de tipos & + & + \\
\hline Restrições de cardinalidade & + & + \\
\hline Documentação & + & + \\
\hline Conhecimento procedimental & + & + \\
\hline Adicionar novas propriedades de atributos & + & + \\
\hline
\end{tabular}

Tabela 3: Definições de Conceitos. 
Metaclasses de conceitos (a possibilidade de uma classe ser uma sub-classe ou "instância" de uma outra) são comuns a ambas as linguagens. O mesmo ocorre com as partições de conceitos, que são conjuntos de classes disjuntas: em ambas sua definição é possível.

Templates (atributos de instância) são atributos cujos valores podem ser diferentes para cada instância do conceito. Atributos próprios de classe são atributos idênticos para todas as instâncias de um determinado conceito. Ambas as linguagem os possuem.

Atributos polimórficos possuem um mesmo nome mas comportamentos diferentes para diferentes conceitos. Esse conceito está presente em ambas as linguagens, assim como o escopo local, apesar de apresentarem funcionamentos diferentes. Valor padrão para um slot é uma característica simples porém bastante útil, que está implementada somente no PowerLoom.

Quanto as restrições de tipos de atributos de slots, ambas as linguagens possuem mecanismos para identificarmos os tipos. Em OWL temos: Any, Boolean, Float, Integer, String e Symbol (owl:oneOf) e cada um desses tipo pode ter ainda diversos subtipos. No PowerLoom só estão disponíveis os tipos Integer, Float e String. Em ambos é possível atribuir uma instância de um conceito como atributo de um outro conceito.

Quanto a cardinalidade em atributos de instâncias, foi analisado em cada linguagem se é possível atribuir um número mínimo e máximo de valores para o atributo. Em ambos essa especificação é possível quanto a propriedades de objetos, mas não de tipos.

Tanto no PowerLoom quanto no OWL é possível documentar os conceitos, relacionamentos e instâncias criadas. Para isto, utiliza-se o comando rdfs: comment no OWL e a palavra chave : document no PowerLoom.

O conhecimento procedimental na definição dos atributos é suportado tanto no PowerLoom como no OWL. Entretanto, devido ao seu comportamento operacional, há mais tipos definições (palavras-chave) no PowerLoom do que no OWL. Esse conhecimento deve ser incluído na definição dos atributos do PowerLoom por meio de palavras-chave tais como: : sufficient, : is, : is-primitive, : inverse ou : implies. Já no OWL esse conhecimento é representado através de rótulos nas definições de classes, tais como: <owl : equivalentClass>, owl: union0f ou owl: Restriction.

Adicionar novas propriedades de atributos é uma operação permitida em ambas as linguagens. 


\begin{tabular}{|c|c|c|}
\hline Taxonomias & PowerLoom & OWL \\
\hline Subclasse de & + & + \\
\hline Partições exaustivas em subclasses & + & + \\
\hline Decomposições disjuntas & + & + \\
\hline Não é uma subclasse de & + & + \\
\hline
\end{tabular}

Tabela 4: Definições de taxonomias.

Na Tabela 4 são comparadas as capacidades quanto a definições de taxonomias.

Tanto PowerLoom quanto OWL permitem definir subclasses. PowerLoom permite até a definição de subclasses de classes não existentes previamente.

Decomposições exaustivas de subclasses definem uma partição como uma subclasse de uma classe. A super-classe é a união de todas as classes que constituem a partição. No OWL é possível definir disjunções sem intersecções ou seja, disjuntas, entretanto não há uma forma simples de especificar isso automaticamente, isto é uma propriedade de cada sub-classe. Há uma forma de especificar a disjunção de todo um grupo de classes, mas se uma classe for inserida futuramente, a ela devem ser aplicadas as disjunções das classes anteriores. Para fazer isso de forma automática, no Protégé, deve-se importar a ontologia de metadados. No PowerLoom podemos fazer disjunções a partir de funções, o que também automatiza completamente o processo. Exemplo:

\section{(mutually-disjoint-collection (set of HIDROLASE TRANSFERASE OXIDOREDUTASE LIGASE LIASE ISOMERASE))}

Decomposições disjuntas definem uma partição como uma subclasse de uma classe. A classificação não necessariamente tem que ser completa (podem existir instâncias da superclasse que não estão incluídas em nenhuma das subclasses da partição). 'Não é uma subclasse de' é usado para afirmar que uma classe não é uma especialização de outra classe. Esse tipo de conhecimento é geralmente representado usando-se a negação da primitiva de subclasse. Exemplo:

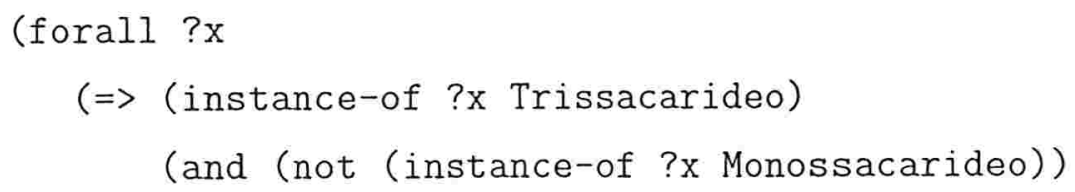




\section{(not (instance-of ?x Dissacarideo)) \\ $($ not (instance-of ?x Polissacarideo)))))}

Essa regra diz que para todo x que seja uma instância de trissacarídeo, ele não será uma instância de monossacarídeo, não será uma instância de dissacarídeo e não será uma instância de polissacarídeo. Isto significa que todas as instâncias de trissacarídeo não são instâncias de monossacarídeos, dissacarídeos ou polissacarídeos.

Já no OWL não é possível fazer uma regra desta forma, sendo que em cada classe deve-se informar sua disjunção com as outras. Por exemplo, a classe dos monossacarideos ficaria assim:

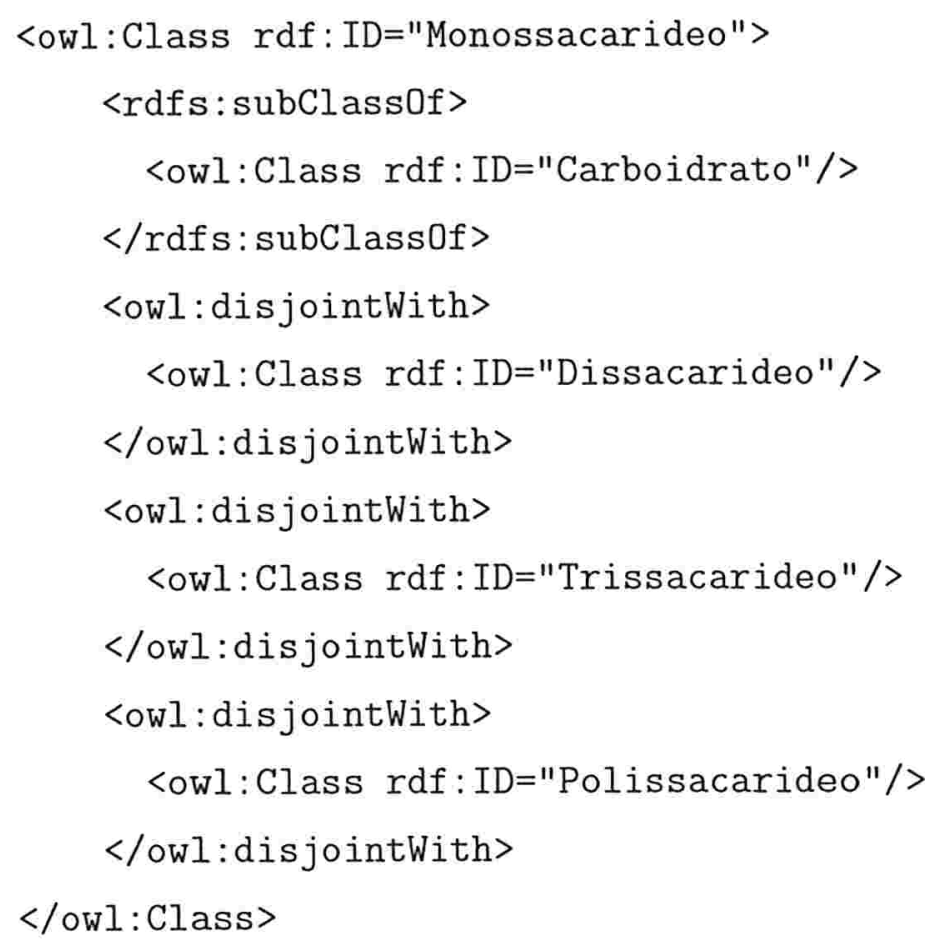

Na Tabela 5 são mostradas as relações e funções do PowerLoom e do OWL.

Como já explicado, funções são um tipo especial de relacionamentos em ambas as linguagens. Também para ambas as linguagens um conceito é uma relação unitária, assim como os slots ou atributos são entendidos como relações binárias entre uma instância e sua propriedade. OWL não pode definir relacionamentos com diversas valências diretamente, deve-se definí-los como classes associativas ou pelo significado de diversos relacionamentos binários. Por isso foi marcado como \pm no item valência de relações e funções. 


\begin{tabular}{|c|c|c|}
\hline Relações e Funções & PowerLoom & OWL \\
\hline Funções como relações & + & + \\
\hline Conceitos como relações unitárias & + & + \\
\hline Slots como relações binárias & + & + \\
\hline Valência de relações e funções & + & \pm \\
\hline Restrições de tipos & + & + \\
\hline Definições operacionais & + & - \\
\hline
\end{tabular}

Tabela 5: Definições de relacionamentos e funções.

\begin{tabular}{|c|c|c|}
\hline Instâncias & PowerLoom & OWL \\
\hline Instâncias de conceitos & + & + \\
\hline Fatos & + & + \\
\hline Alegações (claims) & - & - \\
\hline
\end{tabular}

Tabela 6: Definições de instâncias.

Tanto o PowerLoom como o Protégé fazem restrições de tipos de dados nos atributos de classes, mas só o PowerLoom é capaz de fazer definições operacionais para inferir valores de argumentos com procedimentos, fórmulas e funções ou para definir sua semântica usando axiomas.

Definições operacionais são fórmulas, funções ou regras que podem ser usadas para a obtenção do valor de um atributo.

Na Tabela 6 são comparadas as capacidade de definições de instâncias, fatos e alegações.

Tanto PowerLoom como OWL permitem definir instâncias de conceitos. No PowerLoom é utilizada a palavra chave assert, enquanto no OWL usa-se o nome da classe a qual o conceito pertence precedido de < seguido da palavra chave $r \mathrm{df}: \mathrm{ID}=>$, sendo que entre as aspas duplas fica o nome do conceito. A declaração termina com o nome da classe a qual a instância pertence precedida de $<\backslash$ e seguida de $>$.

Fatos representam uma relação que se mantém entre elementos e estão presentes em ambas as linguagens. Claims (ou alegações) representam asserções sobre um fato de forma episódica, ou seja, por uma instância. Deve-se ressaltar a importância das alegações, já que podem haver várias alegações, conflitantes entre si. Os mecanismos de inferência das linguagens não podem interpretá-las como fatos ou conhecimento, já que podem depois ser inconsistentes com outras alegações. Por exemplo, pode-se imaginar um programa que recolha 


\begin{tabular}{|c|c|c|}
\hline Axiomas & PowerLoom & OWL \\
\hline Lógica de 1a ordem & + & + \\
\hline Lógica de 2a ordem & \pm & - \\
\hline Axiomas nomeados & - & - \\
\hline
\end{tabular}

Tabela 7: Definições de axiomas.

informações na Internet para alimentar uma ontologia. Entretanto, essas informações não devem ser interpretadas como fatos de conhecimento, já que pessoas na Internet podem fazer quaisquer alegações que quiserem, mas sim como alegações sendo feitas por uma instância particular sobre si mesma ou outras instâncias de informação, que podem ser inconsistentes com outras. Num sentido estrito, alegações não estão presentes nas linguagens comparadas, mas deve-se levar em conta a não-monotonicidade do PowerLoom.

Na Tabela 7 são exibidos os tipos de lógica e a presença de axiomas nomeados.

Tanto o PowerLoom como o OWL são baseados na lógica de primeira ordem, entretanto PowerLoom possui várias extensões acima da lógica de primeira ordem (CHALUPSKY; MACGREGOR; RUSS, 2003). Axiomas nomeados são axiomas definidos como elementos independentes na ontologia, e não precisam ser definidos dentro de definições de outros elementos, como relacionamentos, conceitos etc. PowerLoom e OWL permitem apenas axiomas dentro da definição de outros elementos, não permitido axiomas nomeados.

\subsection{Raciocínio e Mecanismos de inferência}

Através dos mecanismos de inferência das linguagens pode-se chegar a asserções que não estão explícitas na base de conhecimento ou mesmo a novos conhecimentos, mesmo que de uma forma probabilística.

Os mecanismos de inferência podem ser usados também para fazer classificações automáticas em uma ontologia, dizendo por exemplo a que conceito pertence uma determinada instância, apenas pelas suas propriedades. Por exemplo, podemos concluir que todo carboidrato com apenas um sacarídeo é um monossacarídeo.

Nesta parte foram comparados os mecanismos de inferência nativos do PowerLoom com diversos mecanismos para OWL. Entretanto, a maior parte deles é bastante simples, como 
o Pellet ${ }^{8}$, o FaCT $++^{9}$ e o $\mathrm{BOR}^{10}$, não permitindo que se façam consultas mais complexas. Então, para fazer inferências na ontologia em OWL, foi escolhido o RACER ${ }^{11}$ em conjunto com o RICE ${ }^{12}$. O RACER é um mecanismo de inferência para lógica de descrição. Ele oferece serviços de inferência para múltiplos TBoxes (definições das classes) bem como ABoxes (instâncias). Ele implementa uma lógica de descrição conhecida como $\mathcal{S H I Q}$ (HORROCKS; PATEL-SCHNEIDER; HARMELEN, 2003). O RICE é um ambiente cliente interativo do RACER. Ele provê uma interface gráfica para o RACER, usando sua API. Com ele é possível navegar em TBoxes e ABoxes e fazer consultas. A versão escolhida foi a RACER 1.7.23. A nova versão do RACER, $1.8 .0^{13}$ é agora um produto comercial com uma licença para estudos válida por 180 dias.

Há um padrão de especificação para uma conexão comum do Protégé com um mecanismo de raciocínio em lógica de descrição. Esse padrão é chamado DIG. Um mecanismo de raciocínio compatível com o DIG é um mecanismo de raciocínio em lógica de descrição que provê uma interface de acesso padrão (conhecida como interface DIG), que permite acesso ao mecanismo através de HTTP, usando a linguagem DIG. A linguagem DIG é uma representação baseada em XML das entidades da ontologia, como as classes, propriedades, indivíduos e axiomas, como as subclasses, axiomas de disjunção e equivalência. A linguagem DIG contém construções que permitem aos clientes que descrevam para o mecanismo uma ontologia, e também realizem sobre ele inferências, como relacionamentos de subclasses, de tipos etc.

Inicialmente foi testado um código OWL semelhante ao PowerLoom, entretanto as restrições de cardinalidade não puderam ser incluídas, já que por restrições da linguagem DIG essas restrições não podem ser passadas para o mecanismo de inferência. DIG não está pronto para lidar com condições necessárias e suficientes para conceitos, como restrições nos slots ou de cardinalidade.

É importante notar que a limitação não é da linguagem OWL, e sim da linguagem para comunicação com os mecanismos de inferência - DIG - e dos próprios mecanismos, que ainda não podem realizar inferências em ontologias com restrições deste tipo.

\footnotetext{
${ }^{8}$ http://www.mindswap.org/2003/pellet/index.shtml

${ }^{9}$ http://owl.man.ac.uk/factplusplus/

${ }^{10}$ http://www.ontotext.com/bor/

${ }^{11}$ http://www.sts.tu-harburg.de/ r.f.moeller/racer/

${ }^{12}$ http://www.b1g-systems.com/ronald/rice/

${ }^{13}$ http://www.racer-systems.com
} 
Além do exposto acima, OWL possui outras restrições:

- Negação; Não é possível dizer explicitamente que uma determinada instância não pertence a uma classe.

- Divisões de Vocabulário; A qualquer recurso é permitido ser somente uma classe, um tipo de dados, uma propriedade de tipo de dados, uma propriedade de objeto, uma instância ou parte do vocabulário padrão, e nada mais do que um destes.

- Tipos explícitos; A partição de todos os recursos deve ser mantida explícita (exemplo: uma classe deve ser declarada se for usada em conjunção com rdfs: subClass0f.

- Separação das Propriedades; O conjunto das propriedades do objeto e as propriedades dos tipos de dados são disjuntas. Então o seguinte nunca pode ser expressado para propriedades de tipos de dados:

- owl:inverse0f

- owl:FunctionalProperty

- owl: InverseFunctionalProperty

- owl: SymmetricProperty

- Não há restrições de cardinalidade transitivas;

- Restrições de Cardinalidades não podem ser colocadas em Propriedades Transitivas;

- Classes Anônimas Restritas. Classes anônimas somente são permitidas se ocorrerem no domínio e escopo tanto de owl: equivalentClass ou owl:disjontWith ou ainda no escopo mas não no domínio de rdfs: subClass0f.

O OWL Lite, tem as mesmas restrições do OWL DL mais as seguintes:

- owl:one0f, owl:disjointWith, owl:union0f, owl:complement0f e owl:hasValue não são permitidos;

- Cardinalidade (minima, máxima e exata) só podem ser feitas com valores 0 ou 1;

- owl : equivalentClass só pode ser aplicado entre identificadores de classe não podendo mais ser aplicado entre classes anônimas. 
Bossam não usa DIG para importar a ontologia, então nele pode ser importada a ontologia completa em OWL. Entretanto, por ainda estar em desenvolvimento, as únicas capacidades presentes são as de consultas simples, como no exemplo abaixo, onde são obtidas todas as instâncias de Carboidratos e Glicídios (sinônimos):

load rdf from file:///home/anderson/Correta.owl;

Knowledge loaded successfully!

load owlrb;

OWL Inference Rules loaded successfully!

ask http://www.ac.endoftheinternet.org/correta.owl\#Carboidrato(?x); No of Bindings: 23

1: $\mathrm{x}=$ http://www.ac.endof theinternet.org/correta.owl\#Lactose

2: $\mathrm{x}=$ http://www.ac.endof theinternet.org/correta.owl\#Maltose

3: $x=$ http://www.ac.endoftheinternet.org/correta.owl\#Estaquiose

4: $x=$ http://www.ac. endoftheinternet.org/correta.owl\#Manose

5: $\mathrm{x}=$ http://www.ac.endof theinternet.org/correta.owl\#Eritrose

6: $\mathrm{x}=$ http://www.ac.endoftheinternet.org/correta.owl\#Sedueptulose

7: $\mathrm{x}=$ http://www.ac.endof theinternet.org/correta.owl\#Eritrulose

8: $\mathrm{x}=\mathrm{http}: / /$ www.ac.endoftheinternet.org/correta.owl\#Xilubiose

9: $\mathrm{x}=$ http://www.ac.endof theinternet.org/correta.owl\#Glicose

10: $\mathrm{x}=$ http://www.ac.endoftheinternet.org/correta.owl\#Arabinose

11: $x=$ http://www.ac.endoftheinternet.org/correta.owl\#Rafinose

12: $\mathrm{x}=$ http://www.ac.endof theinternet.org/correta.owl\#Frutose

13: $\mathrm{x}=$ http://www.ac.endoftheinternet.org/correta.owl\#Xilose

14: $\mathrm{x}=$ http://www.ac.endof theinternet.org/correta.owl\#Galactose

15: $\mathrm{x}=$ http://www.ac.endoftheinternet.org/correta.owl\#Gliceraldeido

16: $\mathrm{x}=$ http://www.ac.endoftheinternet.org/correta.owl\#Celulose

17: $\mathrm{x}=$ http://www.ac.endof theinternet.org/correta.owl\#Amido

18: $\mathrm{x}=$ http://www.ac.endoftheinternet.org/correta.owl\#Celobiose

19: $\mathrm{x}=$ http://www.ac.endoftheinternet.org/correta.owl\#Sacarose

20: $\mathrm{x}=$ http://www.ac.endoftheinternet.org/correta.owl\#Trealose 


\begin{tabular}{|c|c|c|}
\hline Raciocínio & PowerLoom & OWL \\
\hline Classificação & & \\
\hline Classificação automática & + & + \\
\hline Exceções & & \\
\hline Tratamento de exceções & - & - \\
\hline Tipo de Lógica & & \\
\hline Monotônica & + & + \\
\hline Não monotônica & + & - \\
\hline Herança & & \\
\hline Herança simples & + & + \\
\hline Herança múltipla & + & + \\
\hline Procedimentos & & \\
\hline Execução de procedimentos & + & - \\
\hline Constraints & & + \\
\hline Verificação de tipos & + & \\
\hline Encadeamento & & $+($ RACER $)$ \\
\hline Direto & + & - \\
\hline Reverso & + & \\
\hline \multicolumn{2}{|c|}{} \\
\hline
\end{tabular}

Tabela 8: Mecanismos de raciocínio das linguagens.

21: $x=$ http://www.ac.endoftheinternet.org/correta.owl\#Ribose

22: $x=$ http://www.ac.endoftheinternet.org/correta.owl\#Ribulose

23: $x=$ http://www.ac.endof theinternet.org/correta.owl\#DiiDroxiacetona

Na Tabela 8 são comparadas as linguagens quanto aos seus principais mecanismos de inferência disponíveis.

Essa tabela descreve como as estruturas estáticas representadas no domínio do conhecimento podem ser usadas para realizar o processo de raciocínio. Há um forte relacionamento entre as duas dimensões, já que as estruturas usadas para representar o conhecimento são a base para o processo de inferência, como visto na Tabela 1.

Tanto PowerLoom como OWL podem realizar classificações automáticas.

Tratamento de exceções é poder sobrescrever a definição de atributos herdados de um conceito em um subconceito, por exemplo alterando o tipo de dados de uma função. PowerLoom e OWL não dão suporte para isso.

A lógica monotônica é coberta pelos mecanismos de inferência nas duas linguagens, mas a 
lógica não-monotônica só esta presente em PowerLoom. Como exemplo de uso da lógica nãomonotônica pode-se citar o caso das vitaminas. A maior parte das vitaminas é hidrossolúvel, mas algumas são lipossolúveis. Exemplo de uso de lógica não-monotônica:

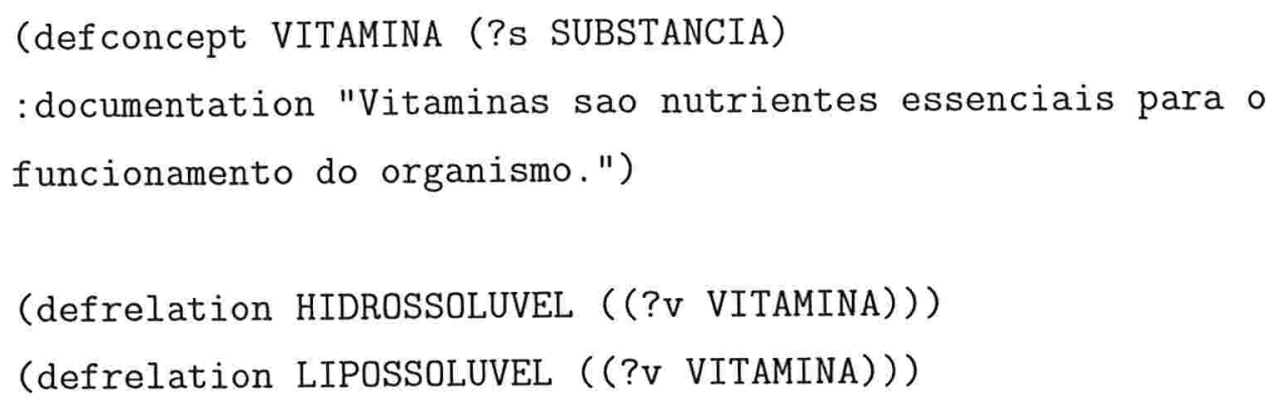

Agora que já existe o conceito vitamina e as relações hidrossolúvel e lipossolúvel, pode-se afirmar que toda vitamina que é hidrossolúvel não é lipossolúvel e vice-versa.

$\mathrm{I}=$ (assert (forall (?v VITAMINA)

$(\Leftrightarrow($ HIDROSSOLUVEL ?v) (not $($ LIPOSSOLUVEL ?v))))

$|\mathrm{P}|$ (FORALL (?v)

$(<=($ NOT $($ LIPOSSOLUVEL ?v)) (HIDROSSOLUVEL ?v)))

$\mathrm{I}=$ (assert (forall (?v VITAMINA)

$(\Leftrightarrow($ LIPOSSOLUVEL ?v) (not (HIDROSSOLUVEL ?v)))))

|P| (FORALL (?v)

(<= (NOT (HIDROSSOLUVEL ?v))

(LIPOSSOLUVEL ?V)))

Como a maioria das vitaminas é hidrossolúvel, pode-se presumir o seguinte:

(presume (forall (?v VITAMINA) (HIDROSSOLUVEL ?v)))

$|\mathrm{p}|$ (FORALL (?x1)

$(<=$ (HIDROSSOLUVEL ?X1)

(VITAMINA $? \times 1)$ ))

Agora são criadas três vitaminas: 


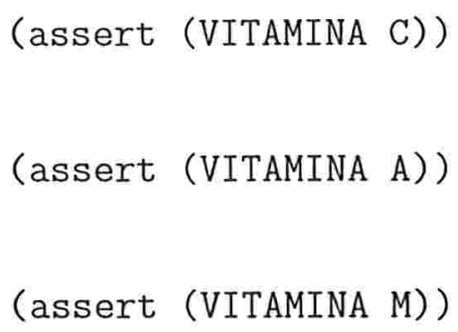

Entretanto, a vitamina A é lipossolúvel, ao contrário do que presumimos. Alterar essa característica não conflita com o que foi presumido ateriormente acerca das vitaminas:

(assert (LIPOSSOLUVEL A))

|P| (LIPOSSOLUVEL A)

E agora novas consultas:

(retrieve all (?v VITAMINA) (LIPOSSOLUVEL ?v)) 
There is 1 solution:

\#1: $\quad$ V $=\mathrm{A}$

(retrieve all (?v VITAMINA) (HIDROSSOLUVEL ?v))

There are 2 solutions:

\#1: ?V=M

$\# 2: \quad ? \mathrm{~V}=\mathrm{C}$

(retrieve all (?v VITAMINA) (not (HIDROSSOLUVEL ?v)))

There is 1 solution:

\#1: ? $\mathrm{V}=\mathrm{A}$

(retrieve all (?v VITAMINA) (not (LIPOSSOLUVEL ?v)))

There are 2 solutions:

\#1: ?V=M

\#2: $\quad$ V $=\mathrm{C}$

Herança simples e múltipla são características encontradas tanto no OWL quanto no PowerLoom, sendo sua definição trivial. Somente o PowerLoom pode executar procedimentos mas ambos fazem verificação de tipos. Ou seja, se um slot é definido para receber inteiros, ele não poderá conter strings ou pontos flutuantes por exemplo.

PowerLoom pode realizar encadeamentos diretos e reversos. Já o RACER realiza somente encadeamentos diretos. Encadeamento direto simplesmente dispara regras quando sua parte condicional é satisfeita. No encadeamento inverso é feita uma tentativa de disparar regras apenas quando essas regras podem potencialmente satisfazer um goal (objetivo). Sistemas de encadeamento reverso automaticamente criam novos subgoals quando mais informação é necessária para determinar se uma dada regra pode ser satisfeita. No encadeamento direto não são criados subgoals automaticamente.

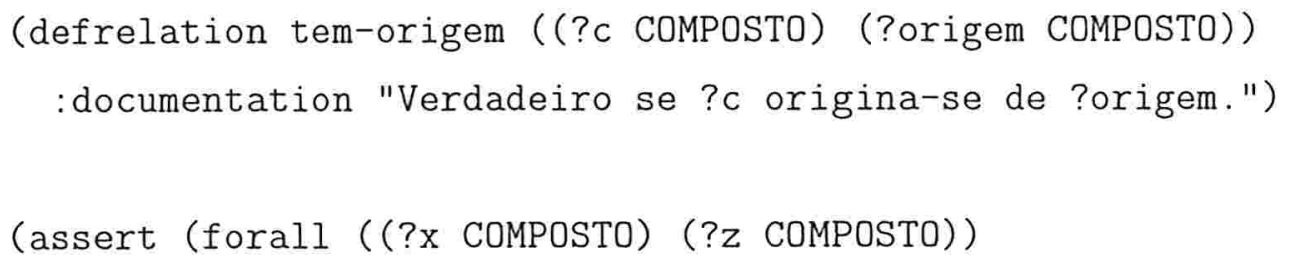


( $\Rightarrow$ (exists (?y COMPOSTO)

(and (tem-origem ?x ?y)

(tem-origem ?y ?z)))

$($ tem-origem ?x ?z))))

No exemplo acima, se ?y dá origem a ?x e ?y origina-se de ?z, então ?z dá origem também a ?x. Esta regra é recursiva, já que seu consequente define um relacionamento tem-origem pela referência recursiva a tem-origem em seu antecedente. Uma arquitetura simples de encadeamento reverso iria encadear para trás no consequente simplesmente enviando os dois novos subgoals de tem-origem do antecedente da regra. Entretanto, esses subgoals seriam duplicatas do goal original, o que poderia levar a uma recursividade infinita. Esta é a estratégia usada pelo Prolog, e a regra de recursão tem que ser manejada cuidadosamente usando conhecimento da ordem em que essas regras e cláusulas são processadas e deve-se organizá-las com cuidado para evitar a recursão infinita. No PowerLoom a ordem das asserções é completamente irrelevante, e subgoals duplicados são detectados automaticamente. Essa é uma característica importante, já que recursão é uma forma muito natural e poderosa para formular axiomas ou regras, e as pessoas às vezes escrevem regras recursivas sem perceberem que o fizeram.

Exemplos das inferências feitas no RACER através do RICE (o símbolo I= será usado antes dos comandos, para diferenciá-los das respostas):

Listar todas as instâncias de glicídios, trissacarídeos e de dissacarídeos ou trissacarídeos:

$\mid=$ (concept-instances $\mid$ Glicidio $\mid$ )

(|Maltose| |Estaquiose| |Lactosel |Xilubiose| |Ribosel |Manosel |Rafinose|

|Eritrose| |Xilose| |Celobiose| |Frutose| |Eritrulose| |Gliceraldeido|

|Trealose| |Celulose| |Sacarose| |Sedueptulose| |Amido| |Ribulose|

|DiiDroxiacetonal |Galactose| |Arabinose| |Glicose|)

$I=$ (concept-instances |Trissacarideo $\mid$ )

( $\mid$ Rafinose|)

$I=$ (concept-instances ( or |Trissacarideo| |Dissacarideo $\mid$ ))

(|Maltosel |Lactose| |Rafinose| |Celobiose| |Trealose| |Celulose| 
|Sacarose |)

Propriedade das instâncias sacarose, amido e glicose:

$\mid=$ (describe-individual |Sacarose $\mid$ )

(|Sacarose| :ASSERTIONS ((|Sacarose| |Dissacarideo|) (|Sacarose| *TOP*))

:ROLE-FILLERS NIL :TOLD-ATTRIBUTE-FILLERS ((|Quantidade_Sacarideos| 2))

:DIRECT-TYPES $((\mid$ Dissacarideo $\mid)))$

A sacarose é um carboidrato que possui quantidade de sacarídeos igual a 2, sendo um dissacarídeo.

$\mid=$ (describe-individual $\mid$ Amido $\mid)$

(|Amido| :ASSERTIONS ((|Amido| |Polissacarideol) (|Amido| *TOP*))

:ROLE-FILLERS NIL :TOLD-ATTRIBUTE-FILLERS ((|Quantidade_Sacarideos| 1400))

:DIRECT-TYPES ((|Polissacarideo $\mid)))$

$I=$ (describe-individual $\mid$ Glicose $\mid$ )

(|Glicosel :ASSERTIONS ((|Glicosel |Monossacarideol) (|Glicose| *TOP*))

:ROLE-FILLERS NIL :TOLD-ATTRIBUTE-FILLERS ((|Quantidade_Sacarideos| 1))

:DIRECT-TYPES ((|Monossacarideo|)))

Essas inferências são simples, já que as restrições de cardinalidade não puderam ser implementadas, pois tratam-se de uma característica que não está presente neste mecanismo de inferência.

O framework Jena ${ }^{14}$ também possui um mecanismo de inferências baseadas em regras em OWL que também foi estudado. Entretanto ele é menos completo que o próprio RACER, já que opera somente com OWL/Lite, enquanto que o RACER pode fazer inferências em parte do OWL/DL. Sendo assim ele também não está apto a fazer as inferências com as restrições de cardinalidade desejadas.

\footnotetext{
${ }^{14} \mathrm{http}: / /$ jena.sourceforge.net/
} 


\subsection{Principais diferenças entre PowerLoom e OWL}

Esta seção é um resumo sobre as principais diferenças entre PowerLoom e OWL, encontradas nas seções anteriores.

As duas linguagens, apesar de apresentarem sintaxes muito diferentes entre si, são muito semelhantes na capacidade de representação de conhecimento. Ambas as linguagens são capazes de definir conceitos, relações e funções. Entretanto, PowerLoom tem um número muito superior de funções pré-definidas, com diversas palavras-chave, que não estão presentes no OWL. Regras de produção estão em estudo no OWL, mas não existem no PowerLoom, apesar de estarem presentes no Loom. Instâncias, seus atributos e defaults, templates e decomposições, bem como meta-classes e partições de conceitos, estão presentes em ambos, apesar de que alegações não são encontradas em nenhum deles.

Enquanto observa-se apenas a parte de representação de conhecimento, as diferenças entre as linguagens não são significativas. Há uma pequena vantagem do PowerLoom se o domínio puder se aproveitar de suas diversas funções internas, como por exemplo, comparações de quantidade, de medidas etc.

Já na parte dos mecanismos de inferência, as diferenças são mais significativas. Por exemplo, no PowerLoom há palavras-chave como below e above, e o mecanismo tem conhecimento sobre diversas unidades de medida, sabendo por exemplo, que 2 polegadas são menos do que 1 metro. As unidades de medidas suportadas são as mais diversas, de indutância até velocidade, passando por massa e pressão por exemplo.

A ausência de mecanismos de inferência capazes de tratar todos os fragmentos OWL/DL deixa o PowerLoom também em vantagem. Restrições de cardinalidade por exemplo, que são comuns no PowerLoom, só podem ser representadas em OWL/DL, e não podem ser importadas por nenhum dos mecanismos de inferência para OWL estudados. PowerLoom permite também recursividade de funções de uma maneira mais completa do que OWL.

Entretanto a principal diferença é que PowerLoom pode fazer uso de lógica não-monotônica, enquanto que os mecanismos de inferência de OWL são restritos à lógica monotônica. Apesar de alguns estudos sendo feitos - (ANTONIOU; HARMELEN, 2004), essa restrição não pode ser contornada facilmente, e pode ser um fator decisivo para a escolha de PowerLoom para a codificação de um domínio do conhecimento em uma ontologia, já que em diversas 
áreas do conhecimento humano, a não-monotonicidade está presente. Na Biologia e em todas as áreas onde o conhecimento está em constante mudança, já que novas informações são descobertas e elas podem conflitar com a informação anterior, a não-monotonicidade do PowerLoom pode fazer diferença, concedendo a ele uma grande vantagem sobre OWL. 


\section{Conclusões e Trabalhos Futuros}

Neste capítulo são apresentadas as conclusões do trabalho, junto com uma perspectiva de trabalhos futuros na área.

\subsection{Conclusões}

Depois de uma introdução ao conceito de ontologia passando por suas definições, o que são e para que servem, neste trabalho foram apresentadas algumas bio-ontologias que estão sendo usadas inicialmente para padronizar o vocabulário na bio-informática, sendo mais enfocada a área de Biologia Molecular. Essa parte foi dividida entre as linguagens e as ferramentas de construção de ontologias. Como a Biologia é uma ciência baseada em conhecimento e um biólogo freqüentemente usa algum tipo de conhecimento pré-existente para fazer inferências sobre um determinado assunto, o uso de ontologias pode facilitar sobremaneira essa tarefa. Além disto, pode-se citar a possibilidade da cooperação na construção de conhecimento, tornando-o disponível também para aplicativos, tarefa que é facilitada pela organização desse conhecimento em formato de ontologia. Espera-se com este capítulo estimular o uso de ontologias, principalmente na área de bioquímica e facilitar a construção de outras novas.

Depois, já que Biologia é uma ciência vasta, onde a abordagem mais lógica é cobrí-la por partes, uma pequena ontologia foi proposta tanto em PowerLoom como OWL, com o intuito de demonstrar algumas vantagens do uso de ontologias para armazenar e inferir sobre o conhecimento armazenado, principalmente na área de bioquímica. Entretanto, devido às diferenças entre as linguagens, algumas inferências somente puderam ser feitas através do PowerLoom, o que motivou a demonstração dessas diferenças entre essas duas linguagens, em termos de expressividade e capacidade de inferência. Nessa parte espera-se alertar sobre as principais ausências do OWL, que farão falta em projetos onde a inferência e o raciocínio 
sobre o conhecimento armazenado são importantes.

A Lógica Clássica que fundamenta a matemática é monotônica, entretanto, os padrões típicos de raciocínio humano, em geral são não-monotônicos (BERNSTEIN; GROSOF, 2003). OWL pode representar bem herança monotônica mas é fundamentalmente incapaz de representar qualquer tipo de raciocínio não-monotônico, incluindo herança não-monotônica. Essa característica é uma das diferenças mais significativas entre as linguagens, já que o PowerLoom é capaz de lidar com o raciocínio não-monotônico. Na Biologia, bem como em outras áreas do conhecimento humano, essa capacidade do PowerLoom é extremamente desejável, concedendo a ele uma grande vantagem sobre OWL.

As principais contribuições deste trabalho foram:

- Demonstrar porque o uso de ontologias para organizar o conhecimento é importante para áreas como a Biologia;

- Discutir as principais bio-ontologias atuais;

- Explicar como se constrói uma ontologia;

- Alertar para os principais problemas e dificuldades que surgem durante a construção e uso de uma ontologia;

- A comparação entre PowerLoom e OWL, no tocante a representação do conhecimento e mecanismos de inferência.

\subsection{Trabalhos Futuros}

A partir deste trabalho, diversos outros poderiam se originar:

- Estudo dos aspectos da representação não-monotônica no PowerLoom e no que ela difere da representação do conhecimento em OWL para possuir essa característica;

- Extensão do OWL de forma a acomodar conhecimento não-monotônico;

- Extensão dos mecanismos de inferência em OWL;

- Extensão da linguagem DIG para a acomodação de OWL/DL completamente; 
- Mecanismos de tradução de OWL para PowerLoom de forma que se pudesse usar seu mecanismo de inferência;

- Organização e categorização unificada de todas as substâncias químicas de interesse na Biologia. 


\section{Apêndice - Código Fonte da Ontologia Proposta}

Nesse apêndice estão descritos os códigos em PowerLoom e OWL da ontologia proposta.

\section{PowerLoom}

Esta ontologia está disponível em: http://www.ime.usp.br/ anderson/ontologias.

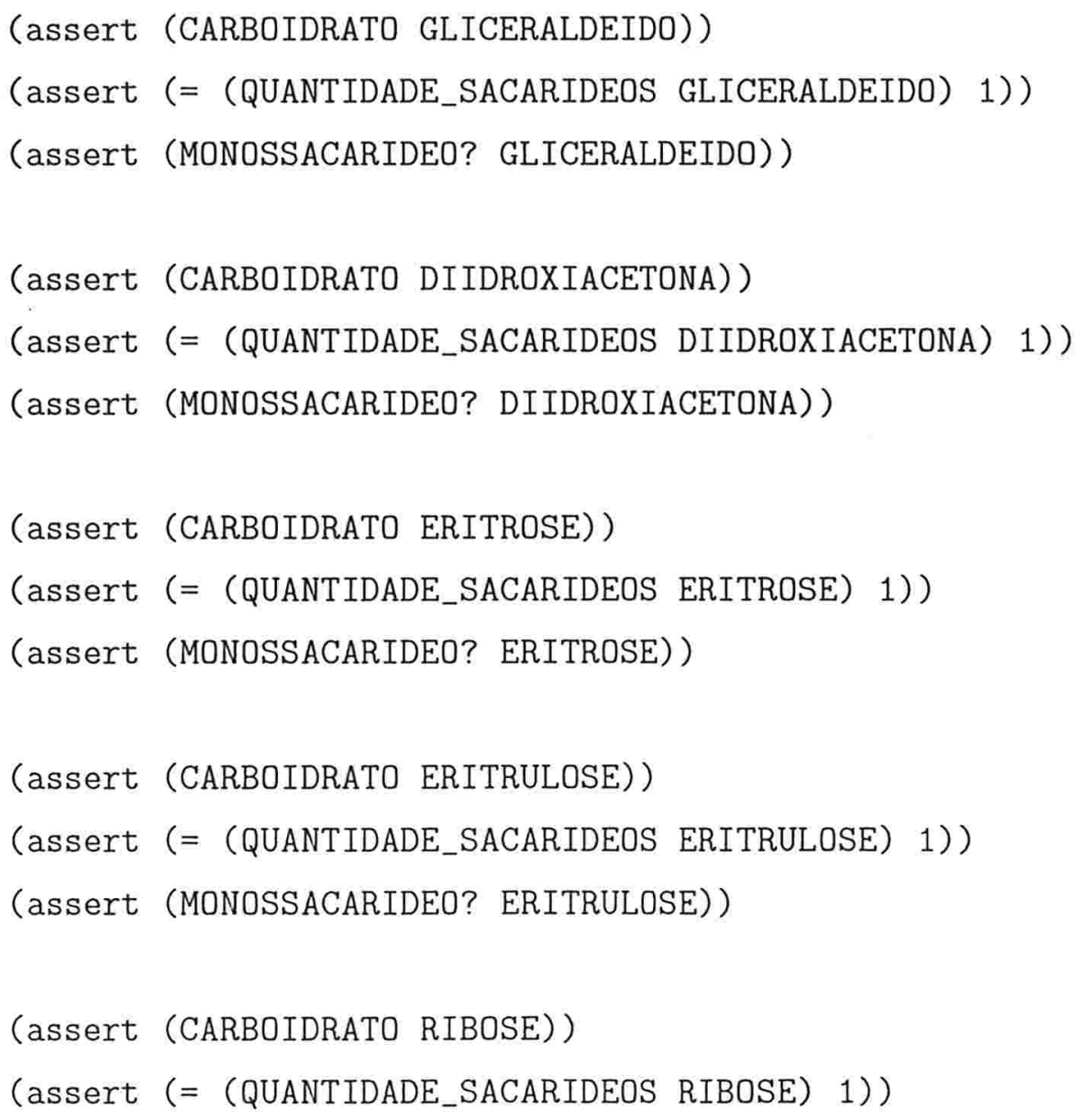




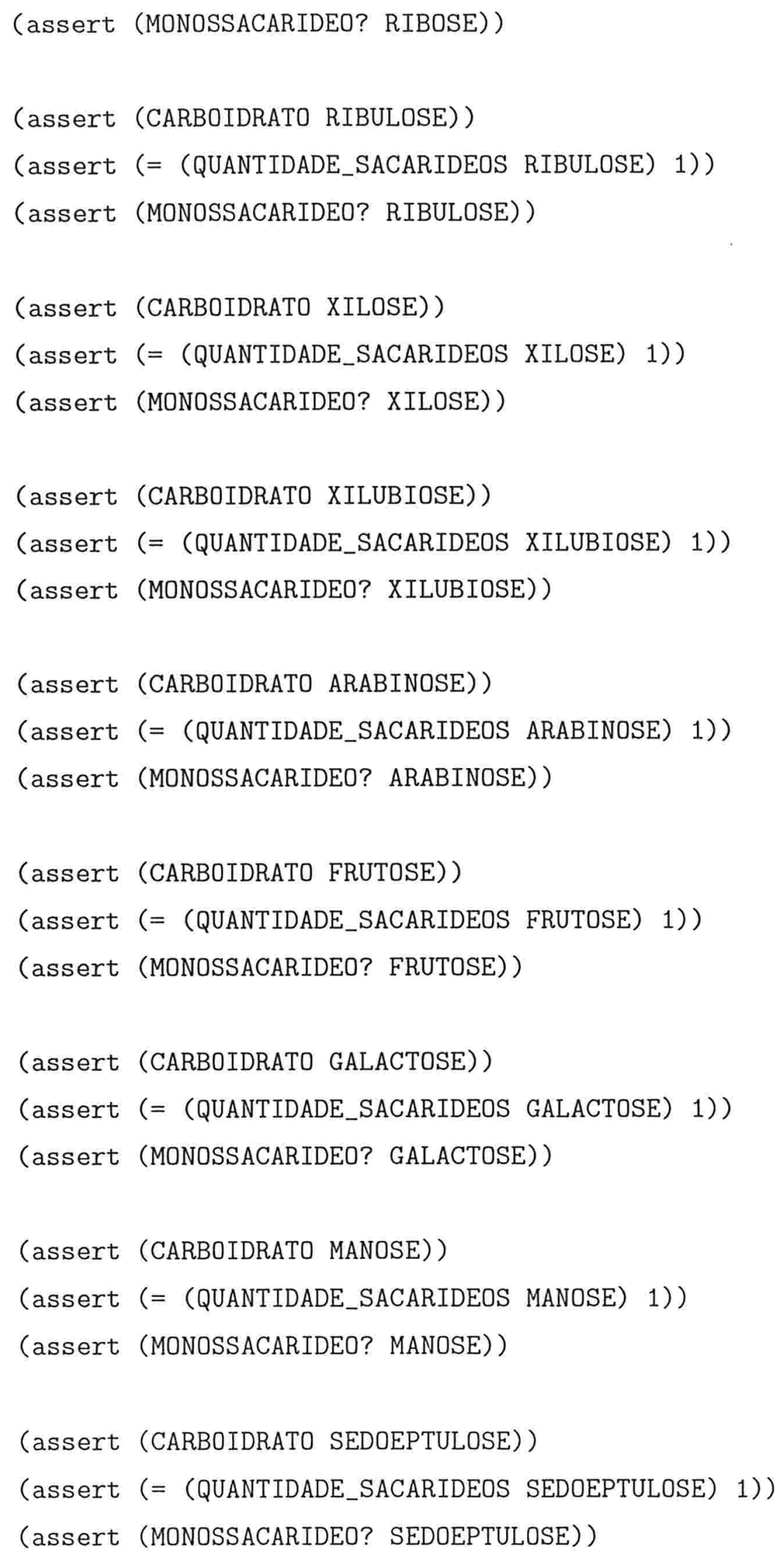


T) Arabinose

$\checkmark$ DiiDroxiacetona

S Eritrose

I) Eritrulose

Tे Frutose

P Galactose

\) Gliceraldeido

i) Glicose

(1) wanose

T Ribose

i) Ribulose

I) Sedueptulose

I) Xilose

T) Xilubiose

Figura 4: As instâncias de Monossacarídeo.

As instâncias de Monossacarídeo estão representadas na Figura 4.

Informações sobre outros tipos de carboidratos:

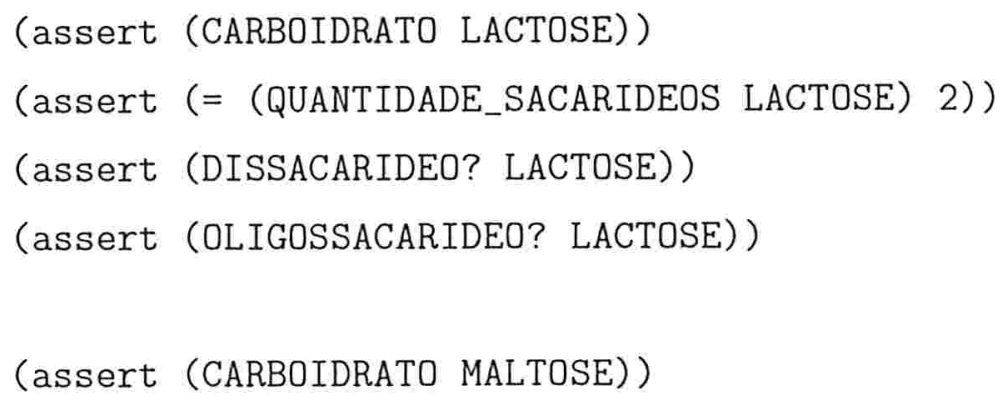




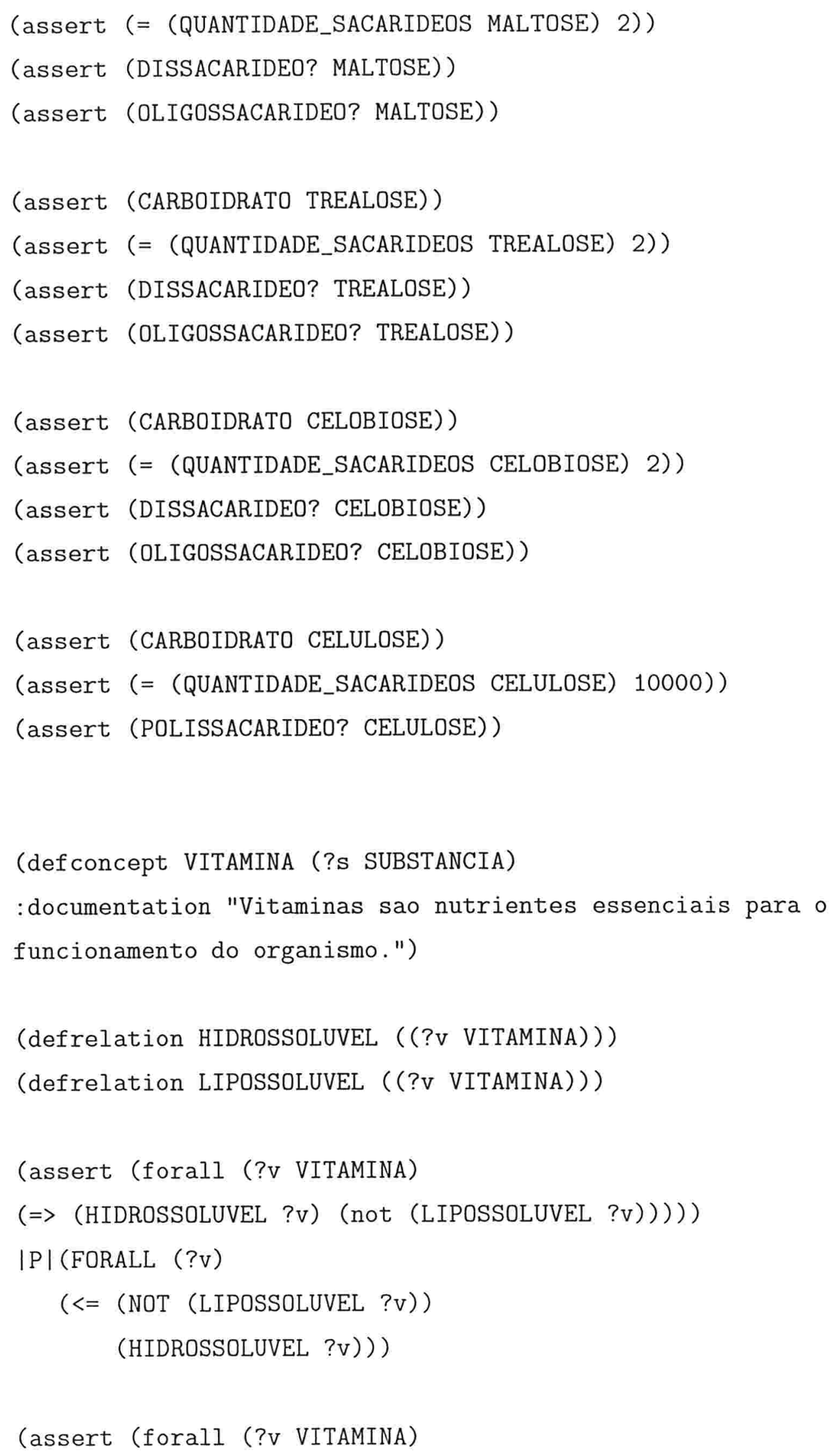


$(\Leftrightarrow($ LIPOSSOLUVEL ?v) (not (HIDROSSOLUVEL ?v))) ))

|P| (FORALL (?v)

$(<=$ (NOT (HIDROSSOLUVEL ?v))

(LIPOSSOLUVEL ?V)))

(presume (forall (?v VITAMINA) (HIDROSSOLUVEL ?v)))

$|\mathrm{p}|$ (FORALL (?x1)

$(<=$ (HIDROSSOLUVEL ?x1)

(VITAMINA $? \times 1)$ ))

(assert (VITAMINA C))

(assert (VITAMINA A))

(assert (VITAMINA M))

Definições das enzimas:

(defconcept ENZIMA (?p PROTEINA))

(def concept HIDROLASE ((?e ENZIMA)

(and (not TRANSFERASE ?e)

(not OXIDOREDUTASE ?e)

(not LIGASE ?e)

(not LIASE ?e)

(not ISOMERASE ?e))

:document "Catalisam reacoes de ruptura, pela adicao de agua, entre um carbono e outro atomo."))

(def concept LIASE ((?e ENZIMA)

(and (not TRANSFERASE ?e)

(not OXIDOREDUTASE ?e)

(not LIGASE ?e) 


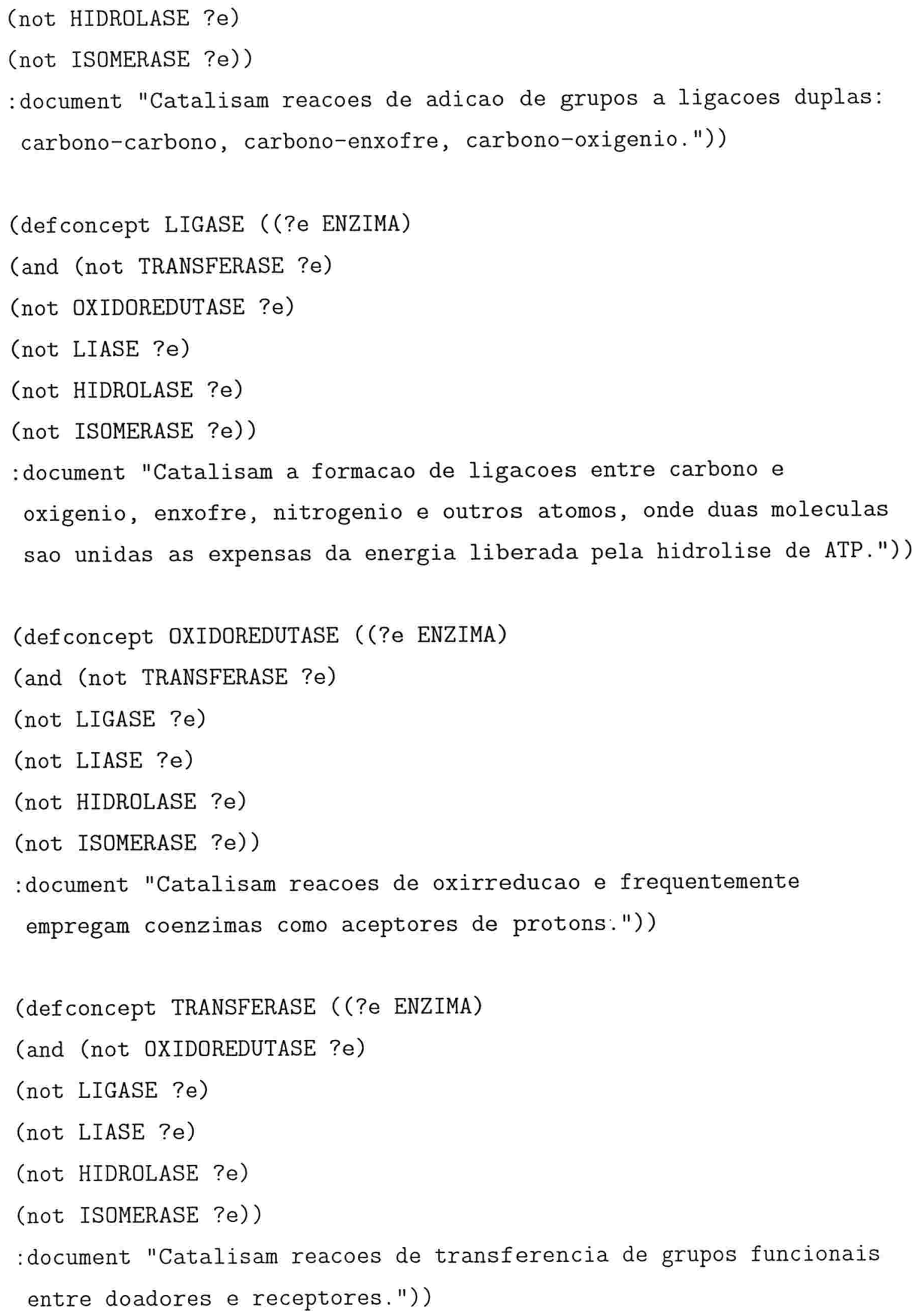


(defconcept ISOMERASE ((?e ENZIMA)

(and (not TRANSFERASE ?e)

(not OXIDOREDUTASE ?e)

(not LIGASE ?e)

(not LIASE ?e)

(not HIDROLASE ?e)))

: document "Grupo bastante heterogeneo de enzimas que catalizam isomerizacoes de varios tipos.")

\section{OWL}

A seguinte ontologia, disponível em http://www.ime.usp.br/ anderson/ontologias, idêntica a ontologia feita no PowerLoom e mostrada na figura 1, foi proposta:

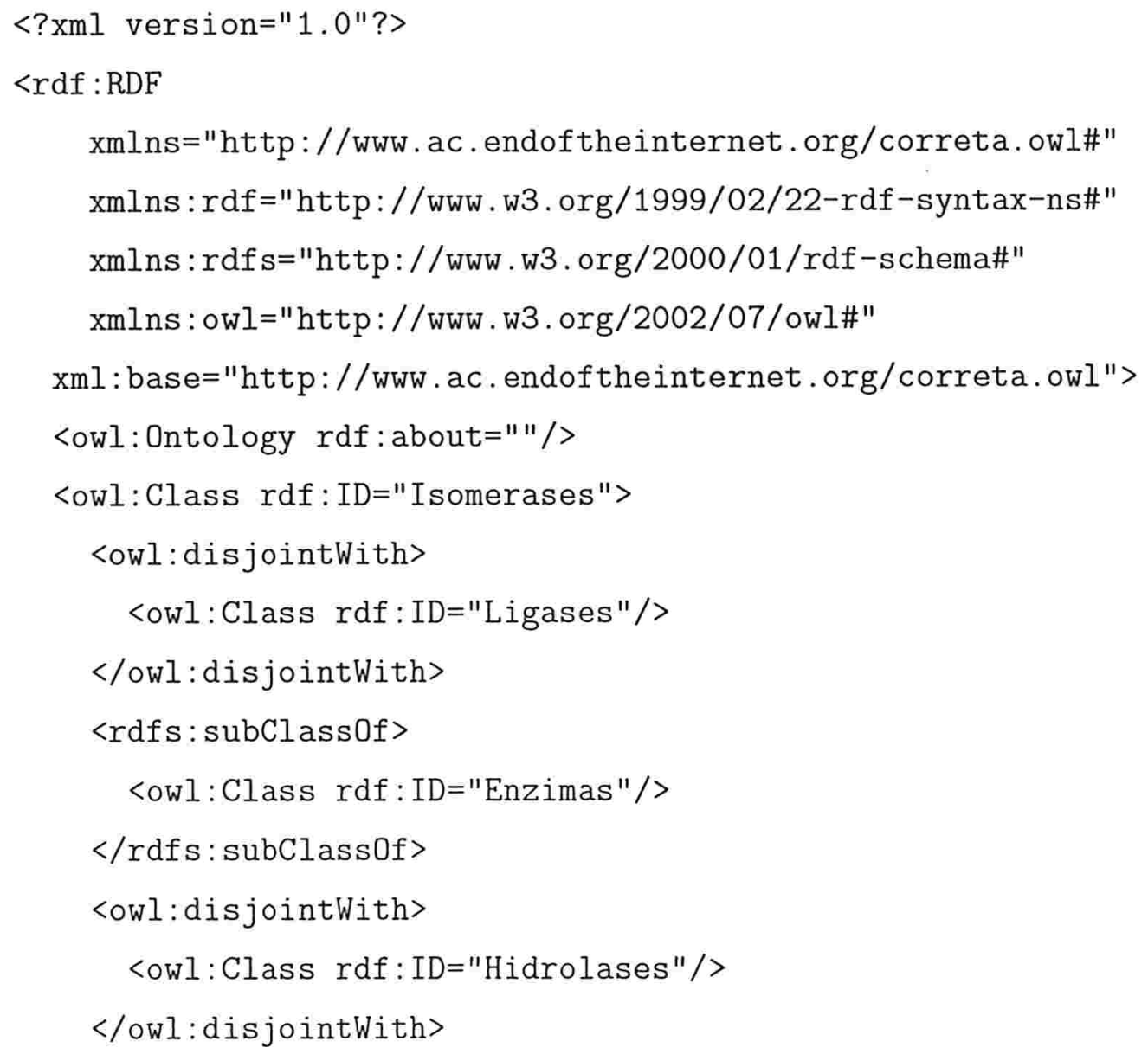




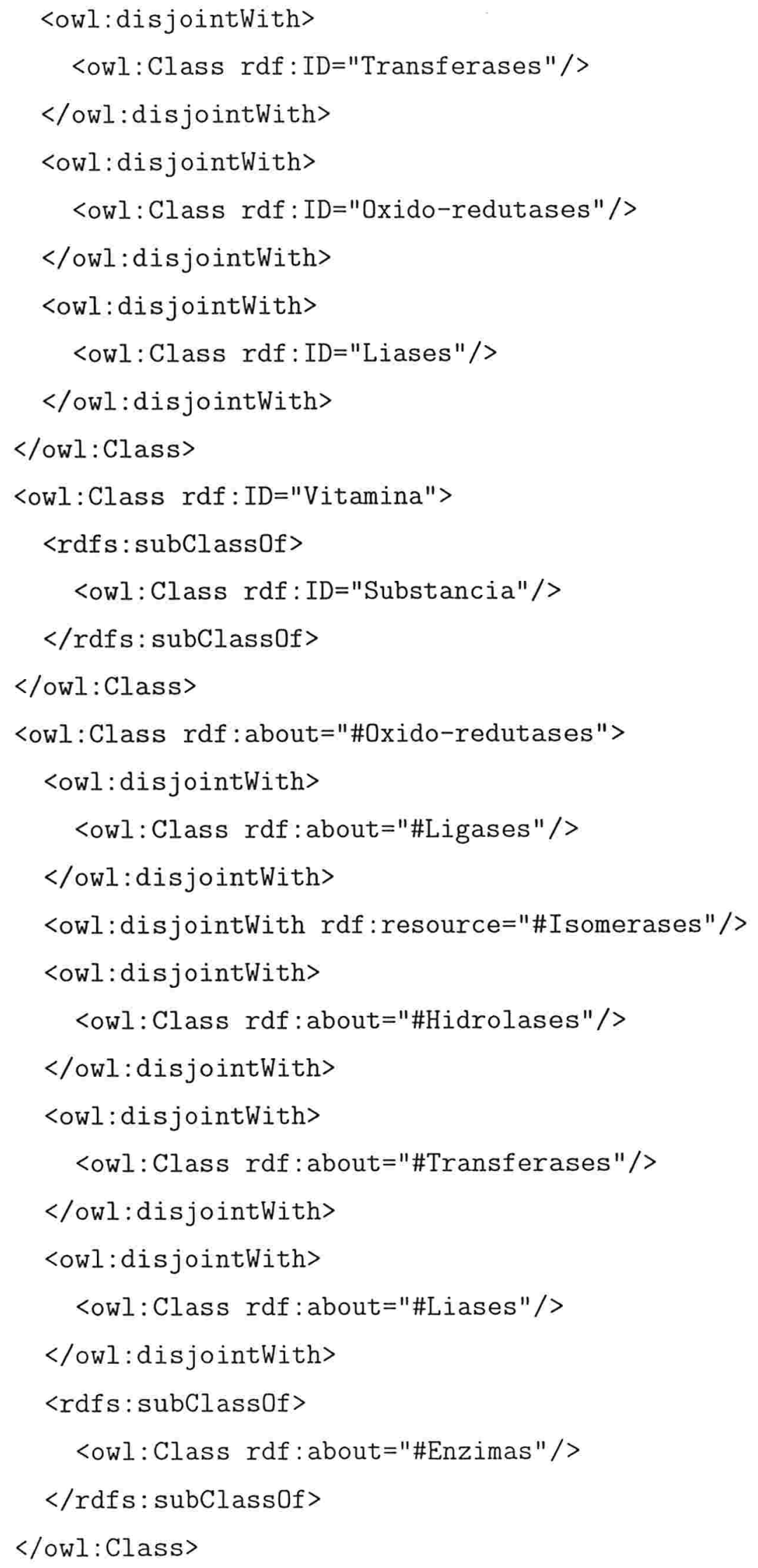




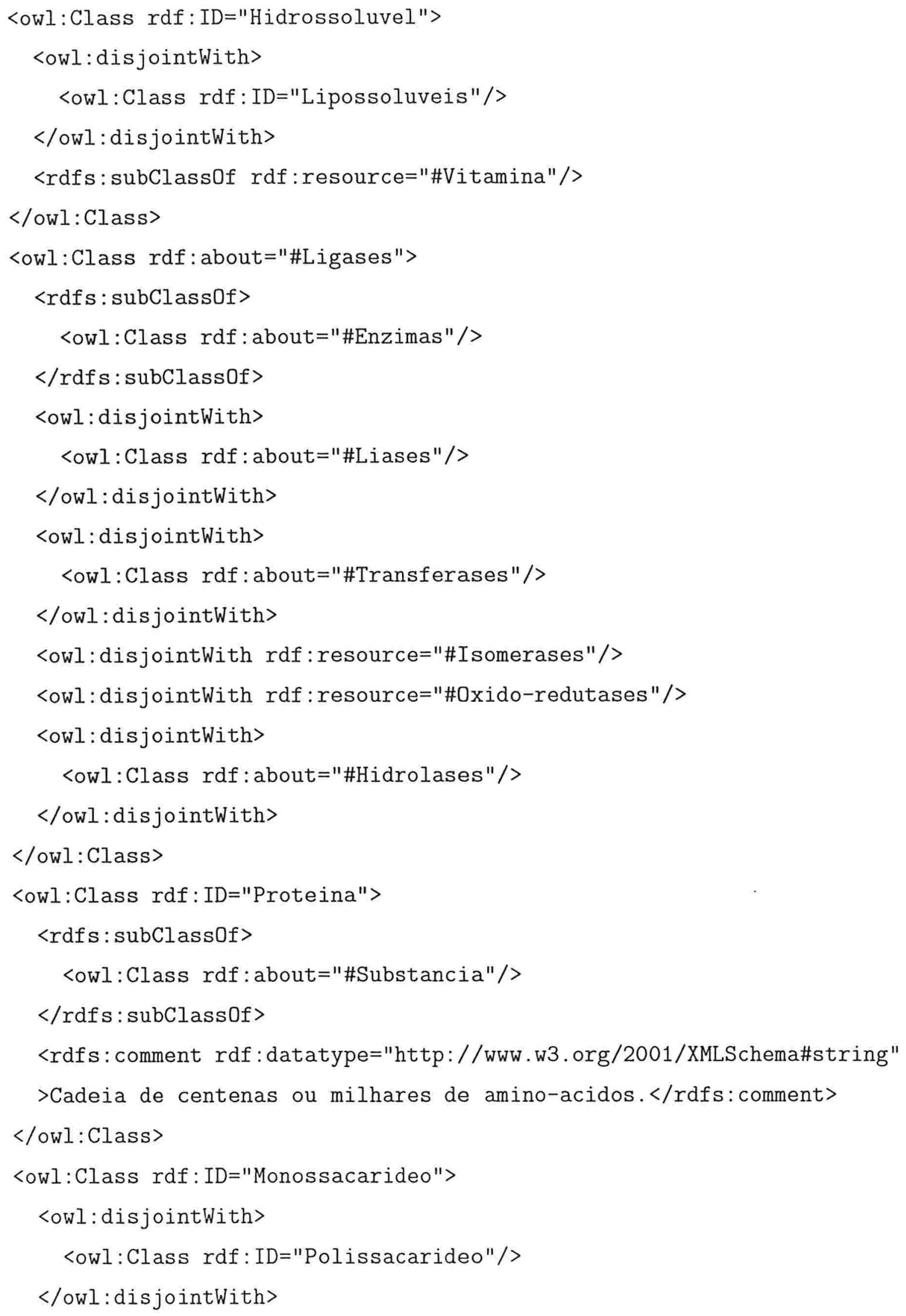




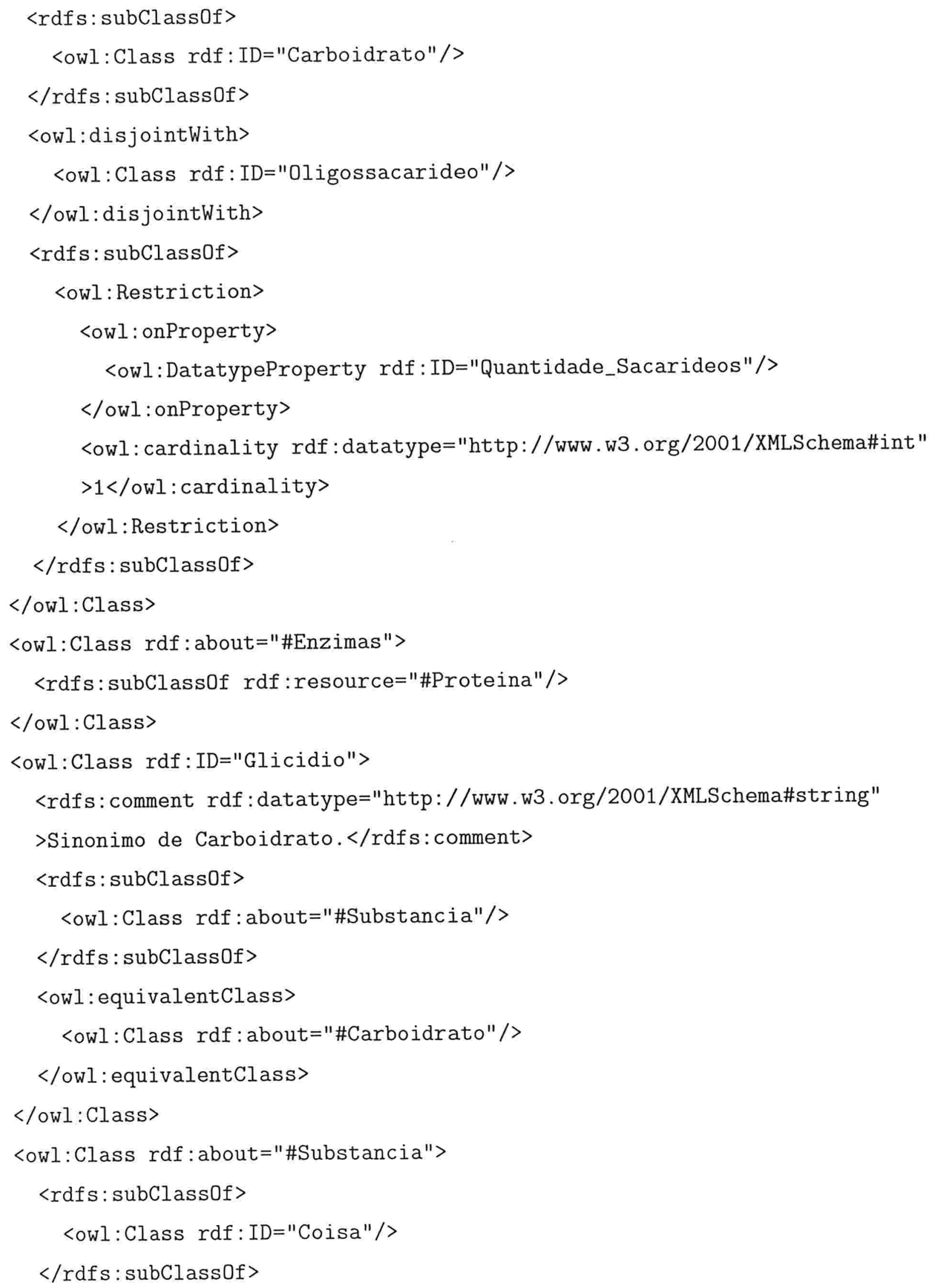


<rdfs: comment rdf: datatype="http://www.w3.org/2001/XMLSchema\#string" $>$ Todos as substancias quimicas serao derivadas

a partir daqui.</rdfs: comment $>$

$</ o w l$ :Class $>$

<owl:Class rdf:about="\#Liases">

<owl:disjointWith rdf:resource="\#Isomerases"/>

<owl: disjointWith rdf:resource="\#Ligases" />

<owl:disjointWith>

<owl:Class rdf:about="\#Transferases"/>

$</ o w l$ :disjointwith>

<owl:disjointWith>

<owl:Class rdf:about="\#Hidrolases"/>

$</ o w l$ :disjointWith>

<rdfs:subClassOf rdf:resource="\#Enzimas"/>

<owl:disjointWith rdf:resource="\#0xido-redutases"/>

$<$ lowl:Class $>$

〈owl:Class rdf:ID="Lipidio">

<rdfs: comment rdf: datatype="http://www.w3.org/2001/XMLSchema\#string"

$>$ Lipidios sao gorduras.</rdfs: comment>

<rdfs:subClassOf rdf:resource="\#Substancia"/>

$</ o w l: C l a s s>$

<owl:Class rdf:ID="Trissacarideo">

$\langle$ rdfs:subClassOf>

<owl:Class rdf:about="\#Oligossacarideo"/>

$\langle/$ rdfs: subClass0f $>$

<owl:disjointWith>

<owl:Class rdf:ID="Dissacarideo"/>

</owl:disjointWith>

</owl:Class>

<owl:Class rdf:about="\#Polissacarideo">

<rdfs:subClass0f>

<owl:Class rdf:about="\#Carboidrato"/>

$</$ rdfs: subClassOf $>$ 
<owl:disjointWith rdf: resource="\#Monossacarideo"/>

<owl:disjointWith>

<owl:Class rdf:about="\#0ligossacarideo"/>

$</ o w l$ : disjointWith $>$

$<$ owl:Class $>$

<owl:Class rdf:about="\#Carboidrato">

<owl: equivalentClass rdf:resource="\#Glicidio"/>

<rdfs:subClass0f rdf:resource="\#Substancia"/>

<rdfs : comment rdf : datatype="http://www .w3.org/2001/XMLSchema\#string"

$>$ Acucar. $\langle/$ rdfs : comment $>$

$\langle/$ owl:Class $>$

<owl:Class rdf:about="\#Lipossoluveis">

<rdfs: subClass0f rdf:resource="\#Vitamina" />

<owl:disjointWith rdf: resource="\#Hidrossoluvel"/>

$<$ owl:Class>

<owl:Class rdf:about="\#Coisa">

<rdfs: comment rdf:datatype="http://www.w3.org/2001/XMLSchema\#string"

$>$ Tudo sera derivado daqui.</rdfs: comment $>$

</owl:Class>

<owl:Class rdf:about="\#Dissacarideo">

<owl:disjointWith rdf:resource="\#Trissacarideo"/>

$\langle$ rdfs: subClassOf>

<owl:Class rdf:about="\#0ligossacarideo"/>

$</$ rdfs: subClass0f $>$

$</$ owl:Class $>$

<owl:Class rdf:about="\#Transferases">

<owl:disjointWith rdf:resource="\#0xido-redutases"/>

<owl:disjointWith rdf:resource="\#Ligases"/>

<owl:disjointWith>

<owl:Class rdf:about="\#Hidrolases"/>

$</ o w l$ :disjointWith>

<rdfs:subClass0f rdf:resource="\#nzimas" />

<owl:disjointWith rdf:resource="\#Liases"/> 
<owl:disjointWith rdf:resource="\#Isomerases"/>

$</$ owl:Class $>$

<owl:Class rdf:about="\#Hidrolases">

<owl:disjointWith rdf:resource="\#Ligases" />

<owl:disjointWith rdf:resource="\#0xido-redutases"/>

<owl:disjointWith rdf:resource="\#Isomerases" />

<rdfs:subClass0f rdf:resource="\#Enzimas"/>

<owl:disjointwith rdf: resource="\#Liases"/>

<owl: disjointWith rdf: resource="\#Transferases" />

$</ o w 1: C l a s s>$

<owl:Class rdf:about="\#Oligossacarideo">

<owl:disjointWith rdf:resource="\#Monossacarideo"/>

<owl:disjointWith rdf:resource="\#Polissacarideo"/>

$\langle$ rdfs: subClass0f rdf:resource="\#Carboidrato"/>

$<$ /owl:Class $>$

<owl:ObjectProperty rdf:ID="Correta_ObjectProperty_2" />

<owl:DatatypeProperty rdf:ID="PPPessoa1">

<rdfs:range rdf:resource="http://www.w3.org/2001/XMLSchema\#string"/>

</owl:DatatypeProperty>

<owl:DatatypeProperty rdf:ID="Relacao">

〈rdfs:range rdf:resource="http://www.w3.org/2001/XMLSchema\#string"/>

<rdfs: comment rdf:datatype="http://www .w3.org/2001/XMLSchema\#string"

$>$ Relacao.</rdfs: comment $>$

<rdfs: domain rdf: resource="\#Proteina" />

</owl:DatatypeProperty>

<owl:DatatypeProperty rdf:about="\#Quantidade_Sacarideos">

<rdfs:domain rdf:resource="\#Carboidrato"/>

<rdfs:range rdf:resource="http://www.w3.org/2001/XMLSchema\#int"/>

$<$ rdf:type rdf:resource=

"http: //www.w3.org/2002/07/owl\#FunctionalProperty"/>

</owl:DatatypeProperty>

<owl: DatatypeProperty rdf: ID="Numero_GO">

<rdfs:domain rdf:resource="\#Coisa" / > 
<rdf:type rdf:resource=

"http://www.w3.org/2002/07/owl\#FunctionalProperty"/>

<rdfs: comment rdf : datatype="http://www .w3.org/2001/XMLSchema\#string"

$>$ Numero GO de referencia.</rdfs:comment $>$

<rdfs:range rdf:resource="http://www.w3.org/2001/XMLSchema\#string"/>

$</ o w l$ :DatatypeProperty>

<owl:DatatypeProperty rdf:ID="Numero">

<rdfs:range rdf:resource="http://www.w3.org/2001/XMLSchema\#string"/>

$</ o w l$ :DatatypeProperty>

<owl: DatatypeProperty rdf:ID="PPPessoa2">

<rdfs:range rdf:resource="http://www.w3.org/2001/XMLSchema\#string"/>

$</ o w l:$ DatatypeProperty>

<owl:DatatypeProperty rdf:ID="Nome">

<rdfs:range rdf:resource="http://www.w3.org/2001/XMLSchema\#boolean"/> $<r d f:$ type $r d f:$ resource $=$

"http://www.w3.org/2002/07/owl\#FunctionalProperty"/>

$</$ owl: DatatypeProperty>

<owl:DatatypeProperty rdf:ID="Cardinal_DatatypeProperty_7">

<rdfs:range rdf:resource="http://www.w3.org/2001/XMLSchema\#string"/>

$</ o w l:$ DatatypeProperty>

<Monossacarideo rdf: ID="Xilubiose">

$<$ Quantidade_Sacarideos rdf:datatype=

"http://www.w3.org/2001/XMLSchema\#int"

$>1</$ Quantidade_Sacarideos $>$

$</$ Monossacarideo>

<Dissacarideo rdf:ID="Lactose">

$<$ Quantidade_Sacarideos rdf:datatype=

"http://www .w3.org/2001/XMLSchema\#int"

$>2<$ /Quantidade_Sacarideos $>$

$</$ Dissacarideo $>$

<Monossacarideo rdf:ID="Eritrulose">

<Quantidade_Sacarideos rdf:datatype=

"http://www . w3.org/2001/XMLSchema\#int" 
$>1</$ Quantidade_Sacarideos $>$

$</$ Monossacarideo>

<Monossacarideo rdf:ID="Gliceraldeido">

$<$ Quantidade_Sacarideos rdf:datatype=

"http: //www . w3.org/2001/XMLSchema\#int"

$>1</$ Quantidade_Sacarideos $>$

$</$ Monossacarideo>

<Monossacarideo rdf:ID="Sedueptulose" />

<Dissacarideo rdf:ID="Sacarose" >

<Quantidade_Sacarideos rdf:datatype=

"http: //www .w3.org/2001/XMLSchema\#int"

$>2</$ Quantidade_Sacarideos $>$

$</$ Dissacarideo $>$

<Dissacarideo rdf:ID="Trealose">

<Quantidade_Sacarideos rdf:datatype=

"http: //www.w3.org/2001/XMLSchema\#int"

$>2</$ Quantidade_Sacarideos $>$

$</$ Dissacarideo $>$

<0ligossacarideo rdf:ID="Estaquiose">

<Quantidade_Sacarideos rdf:datatype=

"http://www.w3.org/2001/XMLSchema\#int"

$>4</$ Quantidade_Sacarideos $>$

$</ 01$ igossacarideo $>$

<Monossacarideo rdf: ID="Arabinose">

<Quantidade_Sacarideos rdf:datatype=

"http://www .w3.org/2001/XMLSchema\#int"

$>1</$ Quantidade_Sacarideos $>$

</Monossacarideo>

<Monossacarideo rdf: ID="Glicose">

$<$ Quantidade_Sacarideos rdf:datatype=

"http://www .w3 .org/2001/XMLSchema\#int"

$>1</$ Quantidade_Sacarideos $>$

$</$ Monossacarideo $>$ 


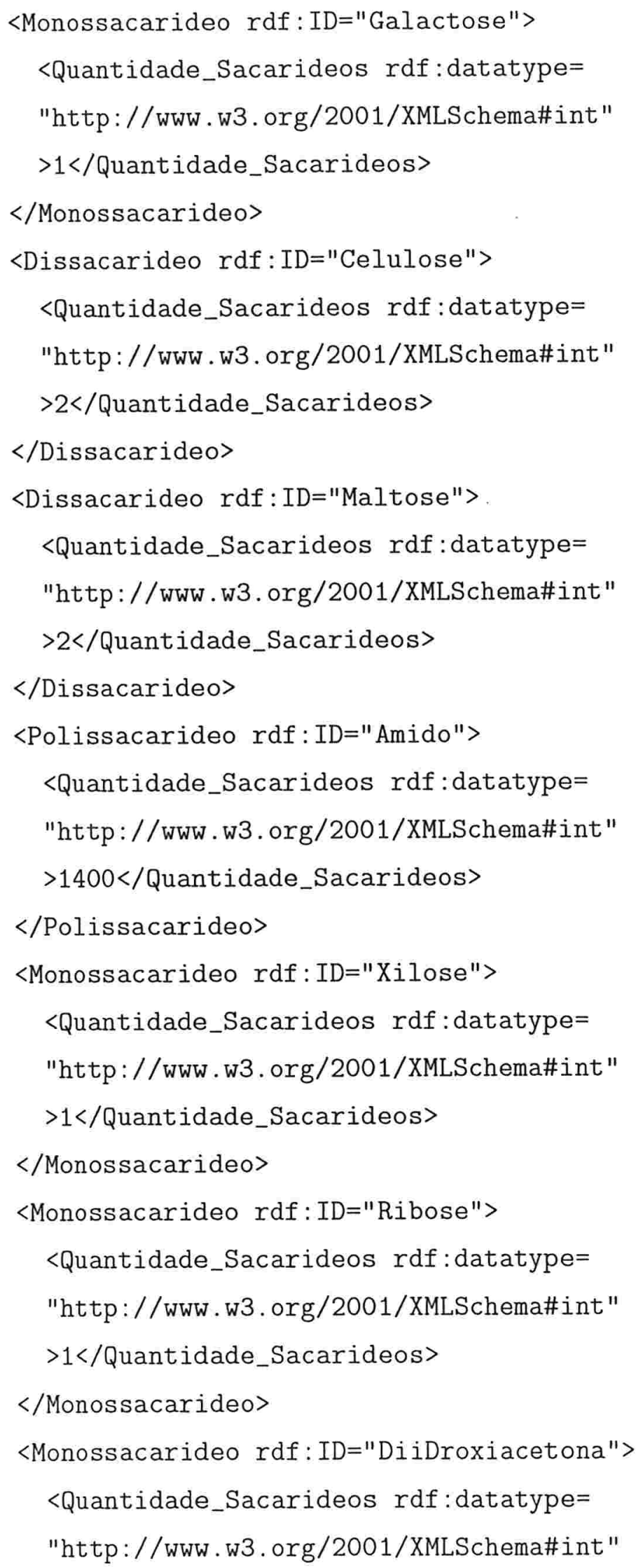




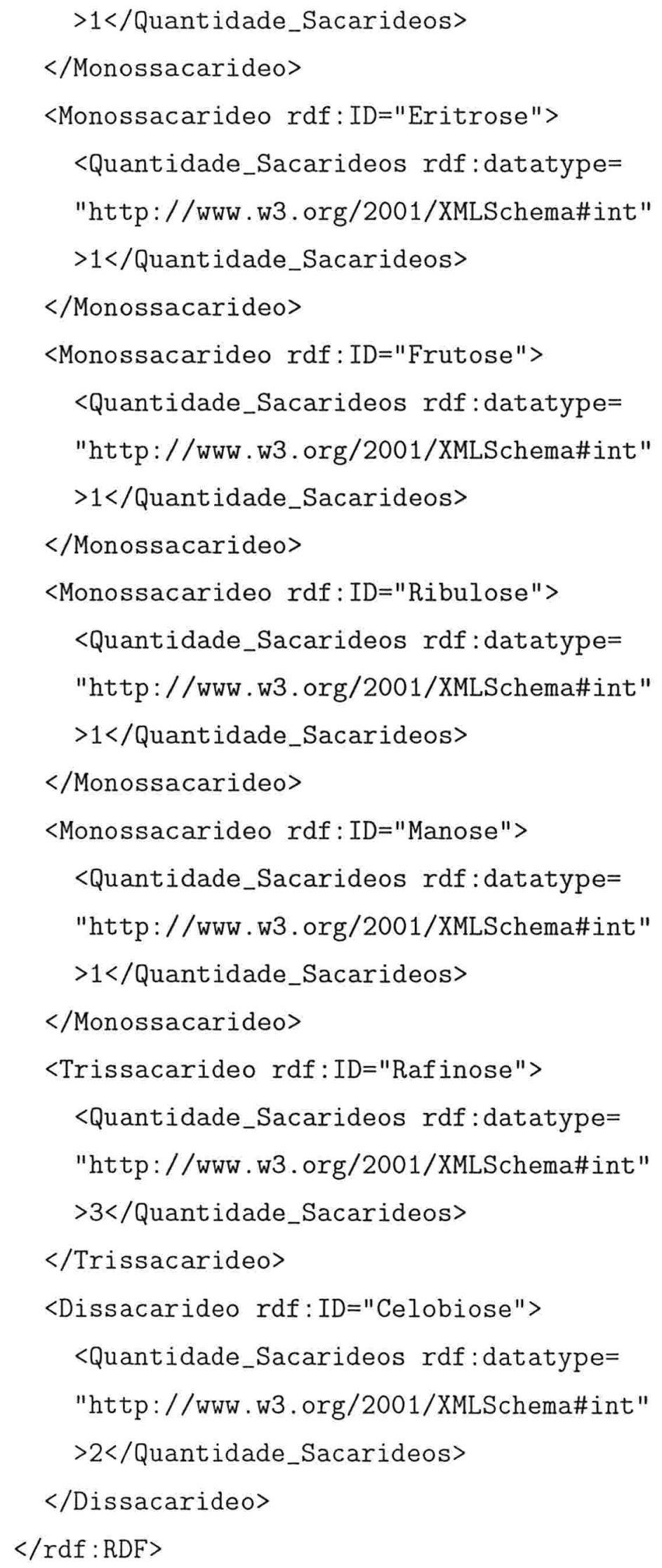


<!-- Created with Protege (with OWL Plugin 1.3, Build 225.4)

http://protege.stanford.edu --> 


\section{Referências}

Antoniou, G.; HARMELEn, F. van. A Semantic Web Primer. 1. ed. Massachusetts: The MIT Press, 2004. ISBN 0-262-01210-3.

BADER, G. D.; CARY, M. P. BioPAX - Biological Pathways Exchange Language Level 2 Documentation. [S.1.], 2005. Disponível em: <http://cvs.sourceforge.net/viewcvs.py/*checkout*/biopax/biopax/release2/biopaxlevel2-documentation.pdf $>$.

BAKER, P. G. et al. TAMBIS: Transparent access to multiple bioinformatics information sources. In: GLASGOW, J. et al. (Ed.). 6th Int. Conf. on Intelligent Systems for Molecular Biology. Montreal, Canada: AAAI Press, Menlo Park, 1998. p. 25-34. Http://imgproj.cs.man.ac.uk/tambis/index.html. Disponível em: <http://citeseer.ist.psu.edu/baker98tambis.html>. Acesso em: 07/10/2005.

BATTISTELLA, E. et al. Bioinformatics: A growing field for ontologies. In: UNISINOS. Proceedings of the Workshop on Ontologies. São Leopoldo, RS, 2004. p. 93 - 103. Disponível em: <http://www.ws.onto.ufal.br/Papers/Battistella.pdf>. Acesso em: 14/10/05.

BECHHOFER, S.; GOBLE, C.; HORROCKS, I. Daml+oil is not enough.

In: Proceedings of the 1st Semantic Web Working Symposium (SWWS

2001). Manchester: CEUR (http://ceur-ws.org/), 2001. p. 151-159.

Http://www.semanticweb.org/SWWS/program/full/paper40.pdf. Disponível em:

<http://citeseer.ist.psu.edu/448137.html>. Acesso em: 07/10/2005.

BECHHOFER, S. et al. Owl web ontology language reference. w3c recommendation. In: DEAN, M.; SCHREIBER, G. (Ed.). World Wide Web Consortium, 2004. Disponível em: <http://www.w3.org/TR/owl-ref/>. Acesso em: 07/10/2005.

BERNSTEIN, A.; GROSOF, B. Beyond Monotonic Inheritance: Towards Semantic WebProcess Ontologies. 2003. Disponível em: <http://ebusiness.mit.edu/bgrosof/paps/beyondmon-inh-wking-pap-081603.pdf $>$. Acesso em: 07/10/2005.

BRAY, T. et al. Extensible markup language (xml) 1.1. In: QUIN, L. (Ed.). World Wide Web Consortium. 2004. Disponível em: <http://www.w3.org/XML/>. Acesso em: $07 / 10 / 2005$.

CHAlupskY, H.; MACGREGOR, R. M.; RUSS, T. PowerLoom Manual - Powerful knowledge representation and reasoning with delivery in Common-Lisp, Java, and C++. California, 2003. Disponível em: 
<http://www.isi.edu/isd/LOOM/PowerLoom/documentation/manual/manual.pdf>. Acesso em: 07/10/2005.

CHAUDHRI, V. K. et al. The Generic Frame Protocol 2.0. [S.1.], 1997. Disponível em: <http://www.ai.sri.com/gfp/gfp2/gfp2.html>.

CHAUDHRI, V. K. et al. OKBC: A programmatic foundation for knowledge base interoperability. In: AAAI/IAAI. Madison: [s.n.], 1998. p. 600-607. Disponível em: $<$ citeseer.ist.psu.edu/chaudhri98okbc.html>. Acesso em: 13/10/05.

COMMON LOGIC WORKING GROUP. Abstract Syntax for the Common Logic standard and its semantics. Texas, 04 2003. Disponível em: <http://cl.tamu.edu/docs/cl/1.0/cl1.0.pdf $>$.

CORCHO, O.; GÓMEZ-PÉREZ, A. A roadmap to ontology specification languages. In: BENJAMINS, R. (Ed.). International Conference on Knowledge Engineering and Knowledge Management. [s.n.], 2000. Disponível em: $<$ http://delicias.dia.fi.upm.es/articulos/ocorcho/ekaw2000-corcho.pdf >. Acesso em: $07 / 10 / 2005$.

DENNY, M. Ontology Building: A Survey of Editing Tools. New York, 07 2004. Disponível em: <http://www.xml.com/pub/a/2004/07/14/onto.html>. Acesso em: 07/10/2005.

GÓMEZ-PÉREZ, A. OntoWeb Ontology-based information exchange for knowledge management and electronic commerce. Karlsruhe, Germany, 05 2002. Disponível em: <http://ontoweb.aifb.uni-karlsruhe.de/About/Deliverables/D13_v1-0.zip>. Acesso em: $07 / 10 / 2005$.

GRUBER, T. R. Towards principles for the design of ontologies used for knowledge sharing. In: GUARINO, N.; POLI, R. (Ed.). Formal Ontology in Conceptual Analysis and Knowledge Representation. Deventer, The Netherlands: Kluwer Academic Publishers, 1993. Disponível em: <http://citeseer.ist.psu.edu/gruber93toward.html>. Acesso em: 07/10/2005.

GRUNINGER, M. Logical Foundations: KIF Working Group Proposal. Texas, 102001. Disponível em: <http://cl.tamu.edu/discuss/kif-100101.pdf>. Acesso em: 13/10/05.

GUARINO, N.; GIARETTA, P. Ontologies and knowledge bases: Towards a terminological clarification. N. J. I. Mars, 1995. Disponível em:

<http://www.ladseb.pd.cnr.it/infor/Ontology/Papers/KBKS95.pdf>. Acesso em: 07/10/2005.

HORROCKS, I.; PATEL-SCHNEIDER, P. F. A Proposal for an OWL Rules Language. Semantics and Abstract Syntax. Manchester, 2003. Disponível em: <http://www.cs.man.ac.uk/ȟrorrocks/DAML/Rules/>. Acesso em: 07/10/2005.

HORROCKS, I.; PATEL-SCHNEIDER, P. F.; HARMELEN, F. van. From $S \mathcal{H I Q}$ and RDF to OWL: The making of a web ontology language. J. of Web Semantics, v. 1, n. 1, p. 7-26, 2003. ISSN 1570-8268. Disponível em: 
<http://www.cs.man.ac.uk/h̃orrocks/Publications/download/2003/HoPH03a.pdf>. Acesso em: 07/10/2005.

JONES, D.; BENCH-CAPON, T.; VISSER, P. Methodologies for ontology development. In: ITEKNOWS Conference, XV IFIP World Computer Congress. Budapest: [s.n.], 2002. Http://cweb.inria.fr/Resources/ONTOLOGIES/methodo-for-onto-dev.pdf. Disponível em: <http://citeseer.ist.psu.edu/135323.html>. Acesso em: 07/10/2005.

KANEHISA, M. et al. The kegg resource for deciphering the genome. Nucleic Acids Research, v. 32, 2004. Disponível em: <http://nar.oxfordjournals.org/cgi/reprint/32/suppl_1/D277>. Acesso em: 07/10/2005.

KöHLER, J.; SCHULZE-KREMER, S. The semantic metadatabase (semeda): Ontology based integration of federated molecular biological data sources. In Silico Biology, 032002. Disponível em: <http://www.bioinfo.de/isb/2002/02/0021/>. Acesso em: 07/10/2005.

MCGUIMMESS, D. L.; HARMELEN, F. van. OWL Web Ontology Language Overview. W3C Recommendation. 2004. Disponível em: <http://www.w3.org/TR/owl-features/>. Acesso em: 07/10/2005.

M. RILEY. Functions of the gene products of escherichia coli. Microbiological Reviews, 1993.

NARDI, D.; BRACHMAN, R. J. Description logic handbook. In: . Cambridge University Press, 2002. cap. An Introduction to Description Logics, p. 5-44. Disponível em: <http://www.cs.man.ac.uk/ franconi/dl/course/dlhb/dlhb-01.pdf >. Acesso em: $07 / 10 / 2005$.

NOY, N.; KLEIN, M.; KUNNATUR, S. The PROMPT Documentation. Stanford, 2004. Disponível em: <http://protege.stanford.edu/plugins/prompt/PROMPT_21_Documentation.zip >. Acesso em: 07/10/2005.

PATEL-SCHNEIDER, P. F.; HAYES, P.; HORROCKS, I. OWL Web Ontology Language Semantics and Abstract Syntax. W3C Recommendation. 2004. Disponível em: <http://www.w3.org/TR/owl-semantics/>. Acesso em: 07/10/2005.

RIBIÈRE, M.; CHARLTON, P. Ontology overview. Paris, 2001. Http://www.fipa.org/docs/input/f-in-00045/f-in-00045.pdf. Acesso em: 07/10/2005.

SCHREIBER, G.; WIELINGA, B.; BREUKER, J. A. P. J. KADS: a principled approach to knowledge based system development. New York: Academic Press, 1993.

SCHULZE-KREMER, S. Ontologies for molecular biology and bioinformatics. Computer and Information Science, v. 6, 2002. Disponível em: <http://www.bioinfo.de/isb/2002/02/0017/main.html>. Acesso em: 07/10/2005.

SIRAVA, M. et al. Biominer: modeling, analyzing and visualizing biochemical pathways and networks. Bioinformatics, p. S219 - S230, 2002. Disponível em: <http://www.brc.dcs.gla.ac.uk/ỹde/Papers/sirava2002.pdf>. Acesso em: 07/10/2005. 
STEVENS, R.; GOBLE, C.; BECHHOFER, S. Ontology-based Knowledge Representation for Bioinformatics. 2000. Http://www.cs.man.ac.uk/s̃tevensr/onto/. Disponível em: <citeseer.nj.nec.com/stevens00ontologybased.html>. Acesso em: 07/10/2005.

STOJANOVIC, L.; MOTIK, B. Ontology evolution within ontology editors. In: Workshop at the 13th International Conference on Knowledge Engineering and Knowledge Management EKAW 2002. Alemanha: FZI - Research Center for Information Technology at the University of Karlsruhe, 2002. Disponível em: $<$ http://km.aifb.unikarlsruhe.de/eon2002/EON2002_Stojanovic.pdf>. Acesso em: 07/10/2005.

STOREY, M. et al. Jambalaya: Interactive visualization to enhance ontology authoring and knowledge acquisition in protégé. In: In Workshop on Interactive Tools for Knowledge Capture. Victoria, B.C. Canada: [s.n.], 2001. Disponível em: <citeseer.ist.psu.edu/storey01jambalaya.html>. Acesso em: 07/10/2005. 